\title{
Large Dense Core Vesicle Exocytosis in Mouse Chromaffin Cells is Regulated by Munc13s and Baiap3
}

\author{
Dissertation \\ zur Erlangung des Doktorgrades \\ der Mathematisch-Naturwissens chaftlichen Fakultäten \\ der Georg-August-Universität zu Göttingen
}

vorgelegt von

Yong Shin

aus Seoul, Korea

Göttingen 2008 
D7

Referent: Prof. Dr. Ernst A. Wimmer

Korreferent: Prof. Dr. Ralf Heinrich

Tag der mündlichen Prüfung: 
Dedicated to my family 


\section{$\underline{\text { Abbreviation Index }}$}

\begin{tabular}{|c|c|}
\hline AMBA & Acrylamide/Bis-Acrylamide-solution \\
\hline Amp & Ampicillin \\
\hline APS & Ammoniumpersulfate \\
\hline A.A & Aminoacid \\
\hline $\mathrm{Bp}$ & Basepair \\
\hline BSA & Bovine Serum Albumin \\
\hline C-terminal & at the $\mathrm{COOH}$-terminus of a protein \\
\hline C-Terminus & $\mathrm{COOH}$-terminus of a protein \\
\hline cDNA & complementary DNA \\
\hline $\mathrm{CNS}$ & Central Nervous System \\
\hline $\mathrm{dH}_{2} \mathrm{O}$ & double distiled water \\
\hline $\mathrm{dCTP}$ & Deoxycytosintriphosphate \\
\hline DEPC & Diethylpyrocarbonate \\
\hline DMEM & Dulbecco's Modified Eagle Media \\
\hline DNA & Deoxyribonucleicacid \\
\hline DNAse & Deoxyribonuclease \\
\hline dNTP's & Deoxynucleocidtriphosphate \\
\hline DTT & Dithiothreitol \\
\hline E. coli & Escherichia coli \\
\hline ECL & Enhanced chemoluminescence \\
\hline EDTA & Ethylene diamine tetraacetic acid \\
\hline EGTA & Ethylene glycol tetraacetic acid \\
\hline ES & Embryonic stem cell \\
\hline et al. & et alteres \\
\hline GFP & Green fluorescence protein \\
\hline GST & Glutathion S-Transferase \\
\hline HEPES & (4-(2-hydroxyethyl)-1-piperazineethanesulfonic acid \\
\hline IPTG & Isopropyl-b-D-thiogalactopyranosid \\
\hline $\mathrm{Kb}$ & Kilobasepair \\
\hline $\mathrm{kDa}$ & Kilodalton \\
\hline $\mathrm{KO}$ & $\begin{array}{l}\text { Knockout, Synonymous for the elimination of a gene in } \\
\text { the mouse }\end{array}$ \\
\hline $\mathrm{M}_{\mathrm{r}} \times 10^{3}$ & relatives Molecularweight in $\mathrm{kDa}$ \\
\hline mRNA & messenger RNA \\
\hline N-terminal & at NH-Terminus a Protein \\
\hline N-Terminus & NH-Terminus a Protein \\
\hline
\end{tabular}




\begin{tabular}{|ll|}
\hline OD & Optical density \\
\hline ON & Overnight \\
\hline PAGE & Polyacrylamide gel electrophoresis \\
\hline PCR & Phosphate Buffered Saline \\
\hline pH & Polymerase-chain reaction \\
\hline PMSF & per Hydrogen \\
\hline RNA & Phenyl-Methylsulfonyl-Fluorid \\
\hline RNAse & Ribonucleicacid \\
\hline RT & Ribonuclease \\
\hline SDS & Room Temperature \\
\hline SNAPs & Sodiumdodecylsulfate \\
\hline SNARE & soluble NSF attachment proteins \\
\hline TEMED & SNAP-Receptor \\
\hline TAQ-Polymerase & N,N,N,N-Tetramethylethan-1,2-diamin \\
\hline TGN & Thermostable DNA-Polymerase from Thermus aquaticus \\
\hline Tris & Trans-Golgi-Network \\
\hline UV & Tris-hydroxymethyl-aminomethane \\
\hline WT & Ultraviolet \\
\hline X-Gal & Wildtype \\
\hline
\end{tabular}




\section{Table of Contents}

1 Introduction 8

$1.1 \quad$ Secretory Vesicles Exocytosis 8

1.1.1 Synaptic Vesicles (SVs) Exocytosis $\quad 9$

1.1.2 Large Dense Core Vesicles (LDCVs) Exocytosis 11

1.1.3 The SNARE Core Complex and SNARE-Regulating Proteins 15

1.2 The Mammalian Unc-13 Protein Family 17

$1.3 \quad$ Munc13-4 and Baiap3/Bap3 20

1.4
Munc13 Proteins and Baiap3/Bap3 in LDCV Exocytosis

2 Materials and Methods 24

$2.1 \quad$ Knock Out Mice 24

2.1.1 Munc13-1, Munc13-2, and Munc13-3 KO Mice 24

2.1.2 Baiap3/Bap3 KO Mice 26

$2.2 \quad$ In Vivo Assays 28

$\begin{array}{lll}2.2 .1 & \text { Cell Cultures and Transfection } & 28\end{array}$

2.2.1.1 Cell Line Culture and Transfection 28

$\begin{array}{ll}\text { 2.2.1.2 Mouse Chromaffin Cells Culture } & 30\end{array}$

2.2.2 SFV Preparation and Infection 31

2.2.3 Protein Extraction from Whole Brain and Adrenal Gland 33

$2.3 \quad$ In Vitro Assays 34

$\begin{array}{lll}2.3 .1 & \text { Contruct Subcloning } & 34\end{array}$

2.3.1.1 Restriction Enzyme and Purification 34

2.3.1.2 Dephosphorylation and Ligation and DNA sequencing 35

2.3.2 Western Blotting 35

2.3.2.1 SDS gel Electrophoresis of Proteins $\quad 35$

2.3.2.2 Coomassie Blue Staining 36

2.3.2.3 Blot Transfer of Protein Gels to Membranes 37

$\begin{array}{lll}\text { 2.3.2.4 Immunoblotting with ECL } & 38\end{array}$

$\begin{array}{lll}2.3 .3 & \text { Northern Blotting } & 40\end{array}$

$\begin{array}{lll}\text { 2.3.3.1 RNA Extraction } & 40\end{array}$

2.3.3.2 Blotting 40

2.3.4 Expression of GST Fusion Proteins 42 
2.3.5 Co-sedimentation Assays 44

2.3.6 Production of Anti-Baiap3 Antisera 45

2.3.7 Antibodies, Chemicals, Kits and Reagents. 47

$2.4 \quad$ Electrophysiological Analysis 50

2.4.1 Whole Cell Capacitance Measurements 50

2.4.2 Flash Photolysis of Caged $\mathrm{Ca}^{2+}$ and Measurements of $\left[\mathrm{Ca}^{2+}\right]_{\mathrm{i}} \quad 52$

2.4.3 Data Analysis and Statistics 53

3 Results $\quad 54$

3.1 Analysis of the Role of the Munc13 Protein Family in LDCV 54

3.1.1 Reduced Exocytosis in Chromaffin Cells from Munc13-1 KO Mice 54

3.1.2 Reduced Exocytosis in Chromaffin Cells from Munc13-2 KO Mice 57

$\begin{array}{ll}\text { 3.1.3 Reduced Exocytosis in Chromaffin Cells from Munc13-1/2 DKO } & 59\end{array}$

3.1.4 Normal Exocytosis in Chromaffin Cells from Munc13-3 KO and 63

3.1.5 Enhanced Exocytosis in Chromaffin Cells from Baiap3 KO Mice 66

3.1.6 Depolarization Induced LDCV Exocytosis in Chromaffin Cells from 68

3.1.7 Reduced Exocytosis in Chromaffin Cells Overexpressing Baiap3 70

$\begin{array}{lll}3.2 & \text { Functional Characterizations of Baiap3 }\end{array}$

3.2.1 Basic Characterization of Baiap3 KO Mice 73

3.2.2 Baiap3 Binds to Both Munc13-1 and Syntaxin $1 \quad 78$

4 Discussion 81

4.1 Munc13s are Positive Regulators of LDCV Exocytosis 81

4.2 Baiap3/Bap3 is a Negative Regulator of LDCV Exocytosis 85

4.3 Munc13s and Baiap3 as Regulators of SNARE-Mediated 89

$\begin{array}{lll}4.4 & \text { Conclusions } & 92\end{array}$

$\begin{array}{lll}4.5 & \text { Future Studies } & 93\end{array}$

5 References $\quad 94$

6 Summary 107 


\section{Introduction}

\subsection{Secretory Vesicle Exocytosis}

Intercellular communication between neurons or neuroendocrine cells is mediated by secretory vesicle exocytosis. Neurotransmitters can be released from two types of vesicles: Synaptic vesicles (SVs), which typically contain classical neurotransmitters such as glutamate or gamma-aminobutyric acid (GABA) and which mediate fast synaptic transmission, and large dense-core vesicles (LDCVs), which typically contain neuropeptides or monoamines and which usually mediate slower modulatory effects. Several characteristic similarities and differences exist between SVs and LDCVs. Both types of vesicles require a $\mathrm{Ca}^{2+}$ trigger in order to fuse, and they share many common proteins that are involved in the control and execution of their membrane fusion. On the other hand, the kinetics of their fusion and its physiological regulation are usually different, indicating the existence of distinct molecular mechanisms in SV- and LDCVmediated secretion (Speese et al., 2007; Zhou et al., 2007). In the present study, I investigated the role of priming proteins of the Munc13 family in the regulation of LDCV-mediated exocytosis. Studies in C. elegans had indicated that the nematode Munc13-homlogue Unc-13 specifically regulates SV priming while the CAPS homologue Unc-31 mediates the corresponding regulatory effect in LDCV fusion (Speese et al. 2007), although Unc-13 may also be required in LDCV exocytosis under certain physiological conditions (Zhou et al., 2007). Similarly, a series of earlier studies in mammalian systems had led to the conclusion that CAPS proteins are selectively responsible only for LDCV-mediated exocytosis (e.g. Tandon et al., 1998; Rupnik et al., 2000; Sadakata et al., 2004 and 2007; Speese et al., 2007). However, a recent study in CAPS deficient mice clearly showed that CAPS proteins are absolutely essential for 
SV-mediated exocytosis (Jockusch et al., 2007), indicating that a restriction of CASPS/Unc-31-dependent regulatory processes to LDCV-mediated secretion may not exist in mammals. The present study was conducted in order to complement these data by analyzing whether Munc13-function in mammals is specific to SVs, as would be indicated by the C. elegans data (Speese et al., 2007; Zhou et al., 2007) or whether they play a more general role in the control of both SV and LDCV fusion.

\subsubsection{SV Exocytosis}

The exocytosis of SVs is part of a complex trafficking cycle consisting of multiple membrane fusion and fission steps and is restricted to so called active zones, where the final steps of vesicle fusion are tightly coordinated in space and time (Wojcik and Brose, 2007; Figure 1).

Transmitters are filled into SVs by dedicated vesicular carriers, whose activity is driven by a proton electrochemical gradient that is generated by a vacuolar-type ATPase. Transmitter-filled SVs in axon terminals dock to the active zone plasma membrane and undergo a biochemical modification called priming. Only these primed and fusioncompetent vesicles are able to fuse with the active zone plasma membrane in response to an action potential and the concomitant influx of $\mathrm{Ca}^{2+}$ through voltage-gated $\mathrm{Ca}^{2+}$ channels. P/Q- and $\mathrm{N}$-type $\mathrm{Ca}^{2+}$ channels are thought to be the main mediators of action potential triggered $\mathrm{Ca}^{2+}$ influx in presynaptic terminals while $\mathrm{R}$ - and I-type $\mathrm{Ca}^{2+}$ channels play a modulatory role (Dietrich et al., 2003). $\mathrm{Ca}^{2+}$ influx triggers two different components of release: A fast component of release (synchronous, phasic) is rapidly induced in as little as $50 \mu \mathrm{s}$ after a $\mathrm{Ca}^{2+}$ stimulus, and a second slow component (asynchronous, tonic) often continues for more than $1 \mathrm{~s}$ after the action potential (Südhof, 1995; Zucker, 1996). After fusion, SV membrane and protein components are 
recycled for reuse. The main recycling pathway involves clathrin-mediated endocytosis. Under certain circumstances however, e.g. during phases of high presynaptic activity, SVs appear to be also recycled in part by a faster pathway, which is termed kiss-andrun, and which is thought to involve direct fission of transiently fusing SVs without a full collapse of the SV into the presynaptic membrane. Endocytosed SVs are reused and refilled with neurotransmitter either directly or after passing through an early endosomal compartment (Wojcik and Brose, 2007; Figure 1).

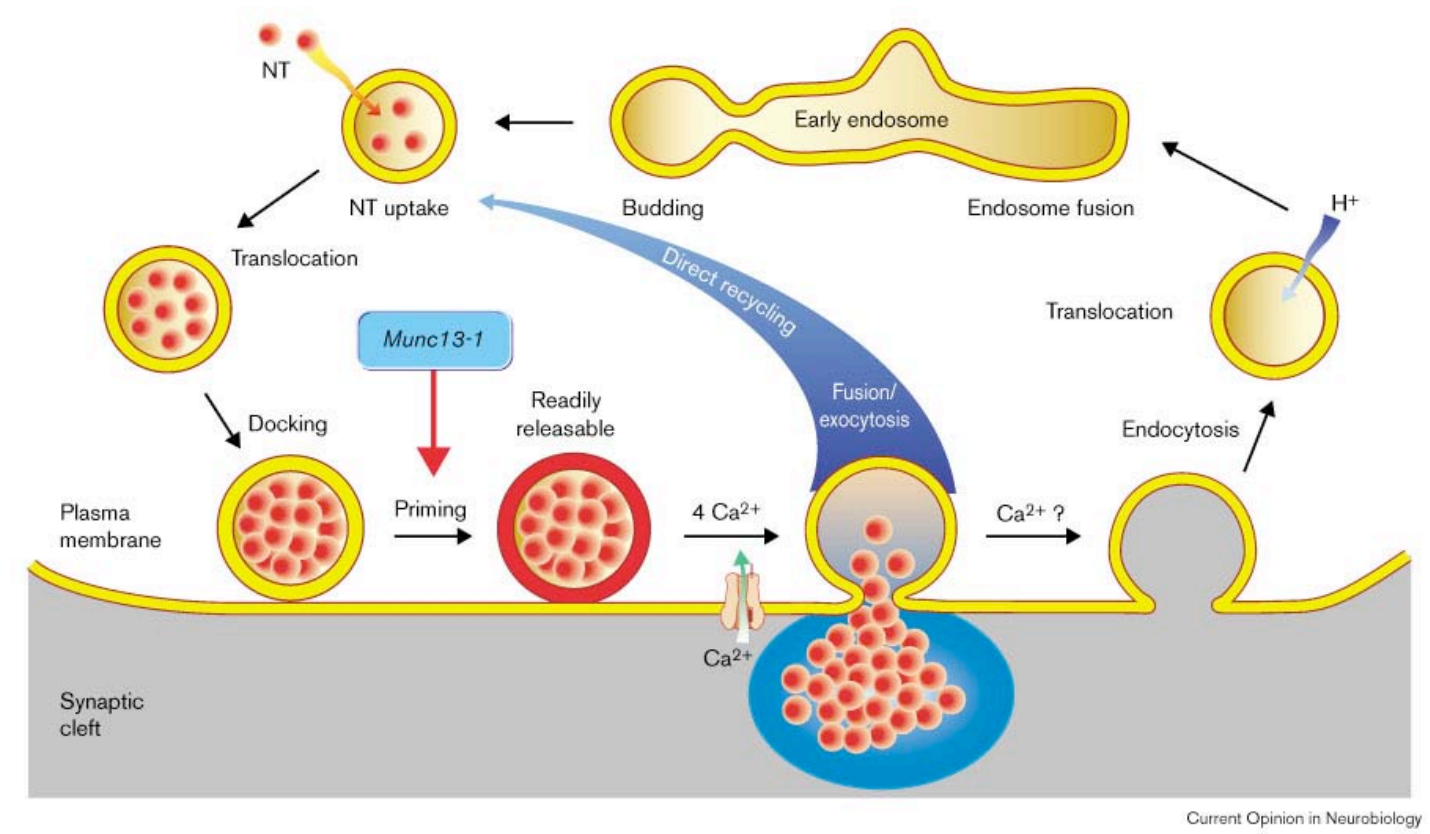

Figure 1. The SV Cycle (image from Brose et al., 2000).

Six large active zone specific proteins - Munc13s, RIMs, Piccolo, Bassoon, ERCs, and $\alpha$-liprins- are involved in the regulation of active zone function. They engage in multiple protein-protein interactions with each other and thereby form a complex active zone protein network. Munc13s (mammalian Unc-13 proteins) and RIMs (Rab3interacting molecules) are multidomain proteins that bind to each other and also interact with multiple other presynaptic protein components (Brose et al., 1995; Wang et al., 1997; Wang et al., 2002). Piccolo and Bassoon are very large homologous proteins of 
the active zone cytomatrix and thought to act as presynaptic scaffold proteins (CasesLanghoff et al., 1996; tom Dieck et al., 1998). ERCs (ELKS/Rab3-interacting molecule/CAST) are coiled-coil proteins that bind to RIMs and to RIM-binding proteins (RIMBPs), which are SH2 (Src homology) domain proteins (Wang et al., 2002; Wang et al., 2000). Finally, $\alpha$-liprins bind to ERCs, RIMs, and several receptor protein tyrosine phosphatases (Ko et al., 2003; Schoch et al., 2002; Serra-Pages et al., 1998).

\subsubsection{LDCV Exocytosis}

As is the case with SVs, LDCV fusion is triggered by transient rises in the intracellular $\mathrm{Ca}^{2+}$ concentration. LDCV fusion has been studied in diverse cell types, including pancreatic exocrine, adrenal chromaffin, and hemopoietic cells, as well as platelets, neutrophils, and mast cells. It appears to share many characteristics and protein components with SV-mediated secretion (Burgoyne and Morgan, 2003; Martin, 1994). Like SV fusion, LDCV fusion is triggered by $\mathrm{Ca}^{2+}$, which typically enters secretory cells after depolarization through voltage-gated $\mathrm{Ca}^{2+}$ channels, and executed by SNAREs, which mediate the membrane merger (Figure 2). In addition, several SNARE regulatory proteins such as Munc18 are common to both vesicle systems. On the other hand, the biogenesis of LDCVs and their fate after fusion are different from the corresponding processes governing SV trafficking. Unlike SVs, LDCVs have to be assembled de novo at the Golgi apparatus owing to the fact that they need to contain enzymes and secreted peptides/proteins (Kim et al., 2006; Dikeakos and Reudelhuber, 2007). In addition, although involving SNAREs, their cell biological mechanism of fusion (e.g. compound fusion vs. individual vesicle fusion), and their recycling may also be different from SV-related mechanisms (Rutter and Hill, 2006). 

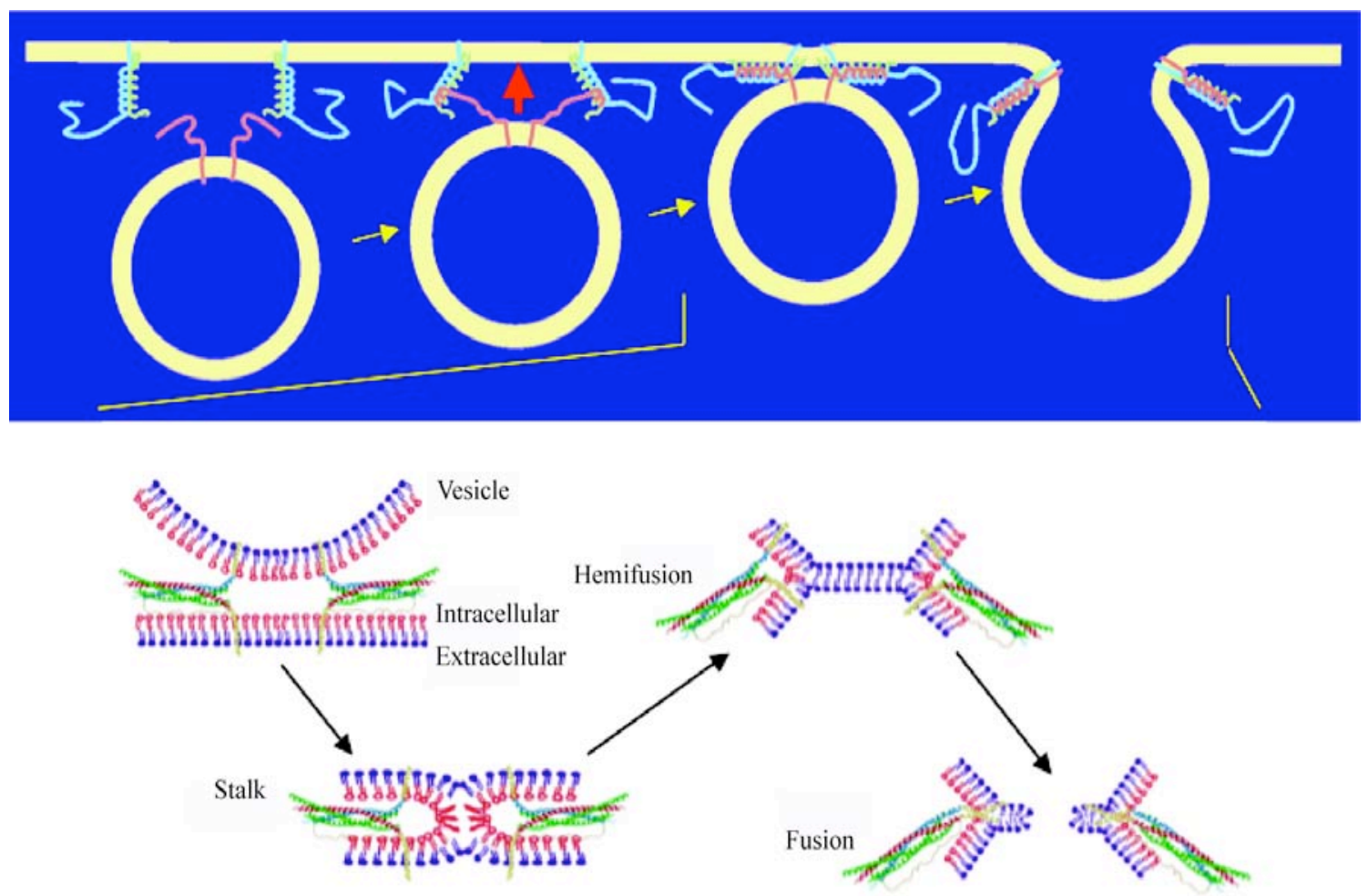

\section{Figure 2. The SNARE Complex.}

Vesicular and plasma membrane SNARE proteins assemble into the trimeric SNARE complex. Assembly of this complex is thought to drive the membrane fusion reaction (top), possible via (stalk-like) hemifusion intermediates (bottom). Images are from R. Jahn, Göttingen.

LDCV secretion has been best characterized in adrenal chromaffin cells. These cells are part of the adrenal medulla, which contains three types of chromaffin cells, adranaline(85\%), noradrenaline- (14-15\%), and dopamine-containing cells ( $<1 \%)$ (Figure 3$)$. All three types of hormone are synthesized from tyrosine in the adrenal medulla (Trifaro, 2002). A single chromaffin cell contains about 30,000 vesicles or chromaffin granules (Carmichael and Winkler, 1985), which contain a mixture of hormones and neuropeptides.

Due to their spherical shape, chromaffin cells are nicely amenable to electrophysiological recordings of membrane capacitance, membrane characteristics, and ion fluxes. By combining flash-photolysis of caged $\mathrm{Ca}^{2+}$ or depolarizing stimuli 
with patch-clamp recordings of membrane capacitance and amperometric recordings of released catecholamines, chromaffin cells can be used to study all aspects of LDCV fusion with very high temporal resolution and in highly reliable quantitative terms. This extraordinary experimental accessibility together with the fact that they are derived from the neural crest, i.e. from the same precursors that give rise to sympathetic neurons, have led to the widespread use of chromaffin cells as a model system for the analysis of regulated transmitter release.

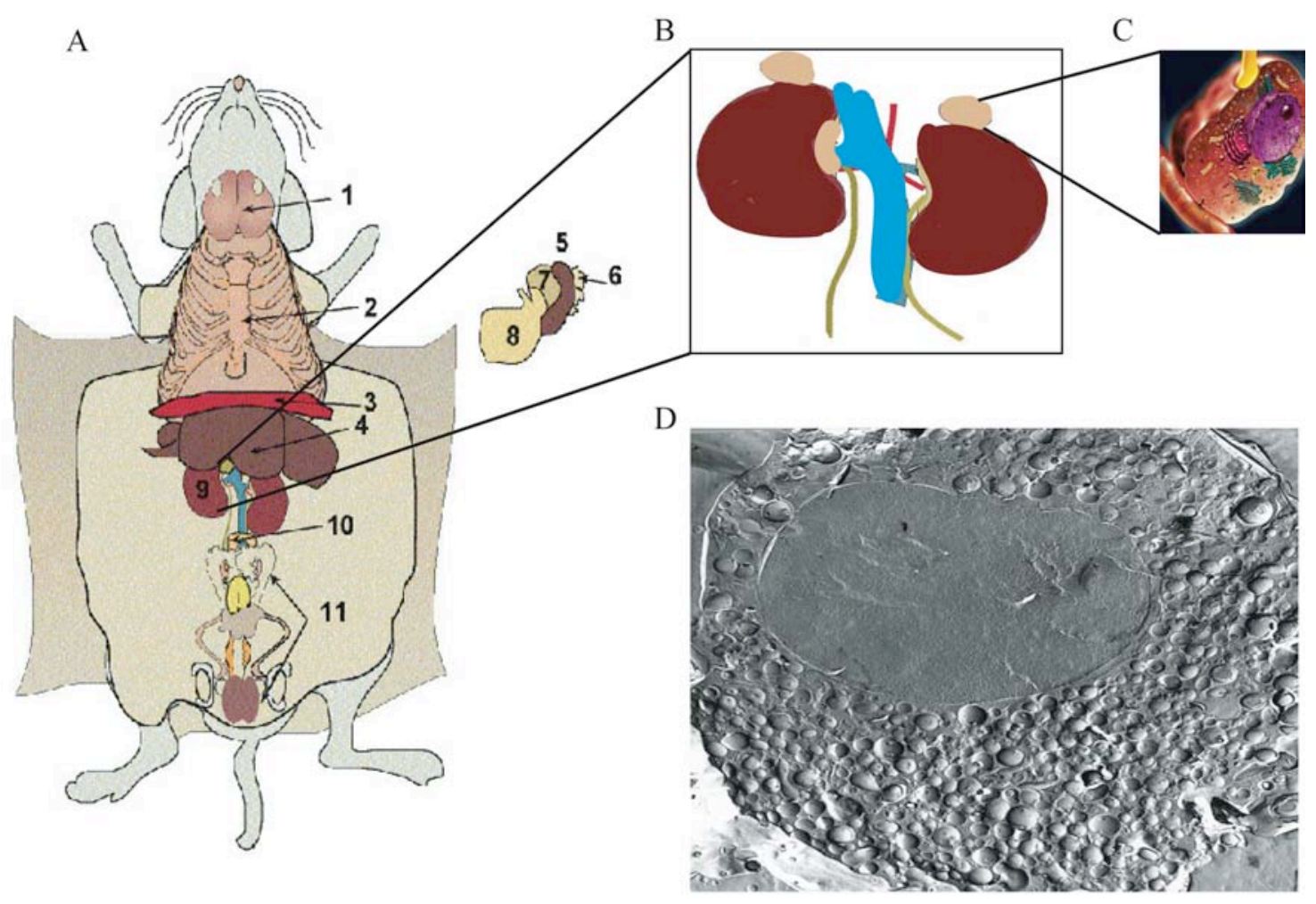

\section{Figure 3. Chromaffin Cells From the Mouse Adrenal Medulla.}

(A) Organs in the mouse abdomen (from http://www3.niaid.nih.gov). 1. Salivary gland, 2. rib cage, 3. diaphragm, 4. liver, 5. spleen, 6. pancreas, 7. forestomach, 8. glandular stomach, 9. kidney, 10. ascending colon, 11. male urogenital system. (B-C) Adrenal glands lie above both kidneys. (D) Scanning electron micrograph of a chromaffin cell (from http://webpages.ull.es).

The LDCVs of adrenal chromaffin cells can be classified functionally into distinct pools. These are distinguished based on their release kinetics, which in turn can be deduced from the shape of the typical membrane capacitance traces measured after 
depolarizations or $\mathrm{Ca}^{2+}$ release from a previously infused photolabile chelator using UV-flash photolysis (Figure 4). Within the first second after flash photolysis of caged $\mathrm{Ca}^{2+}$, a readily releasable pool (RRP) of vesicles fuses in an exocytotic burst, which consists of a fast and a slow component. The vesicles from the fast burst component of flash photolysis experiments correspond to the RRP released in response to a more physiological depolarization stimulus and fuse with a time constant of about 20-40 ms. Vesicles from the slow burst, which are also referred to as the slowly releasable pool (SRP), fuse with a time constant of about $200 \mathrm{~ms}$ (Becherer and Rettig, 2006). These slow burst vesicles are not released by depolarization, but they represent a precursor pool of the fast burst/RRP vesicles (Voets et al., 1999). In addition to these vesicle pools, depolarizing stimuli allow the detection of those vesicles situated closest to $\mathrm{Ca}^{2+}$ channels as an immediately releasable vesicle pool (IRP) (Schneggenburger and Neher, 2005). The IRP vesicles are also released during flash photolysis, but due to the global increase in intracellular $\mathrm{Ca}^{2+}$ cannot be distinguished as a separate pool.

Unlike SVs, the readily releasable pools of LDCVs in adrenal chromaffin cells are not concentrated at active zones but rather docked and primed at the entire plasma membrane (Allersma et al., 2004; Olofsson et al., 2002; Parsons et al., 1995). Exocytotic delay times and release rates are typically slightly longer in LDCVs than in SVs (Voets et al., 1999 and 2000). The pool of release ready vesicles is refilled from vesicles of the unprimed pool (UPP), which are close to but morphologically detached from the plasma membrane by some $200 \mathrm{~nm}$. The sustained component is the final phase of the capacitance trace after flash photolysis. It is due to docking and priming of vesicles from the UPP and subsequent fusion. Vesicles in the UPP are replenished from a depot pool (DP), which represents the largest pool of LDCVs in adrenal chromaffin cells. The DP is composed of the vesicles that are more than $200 \mathrm{n}$ away from the plasma membrane (Becherer and Rettig, 2006). 

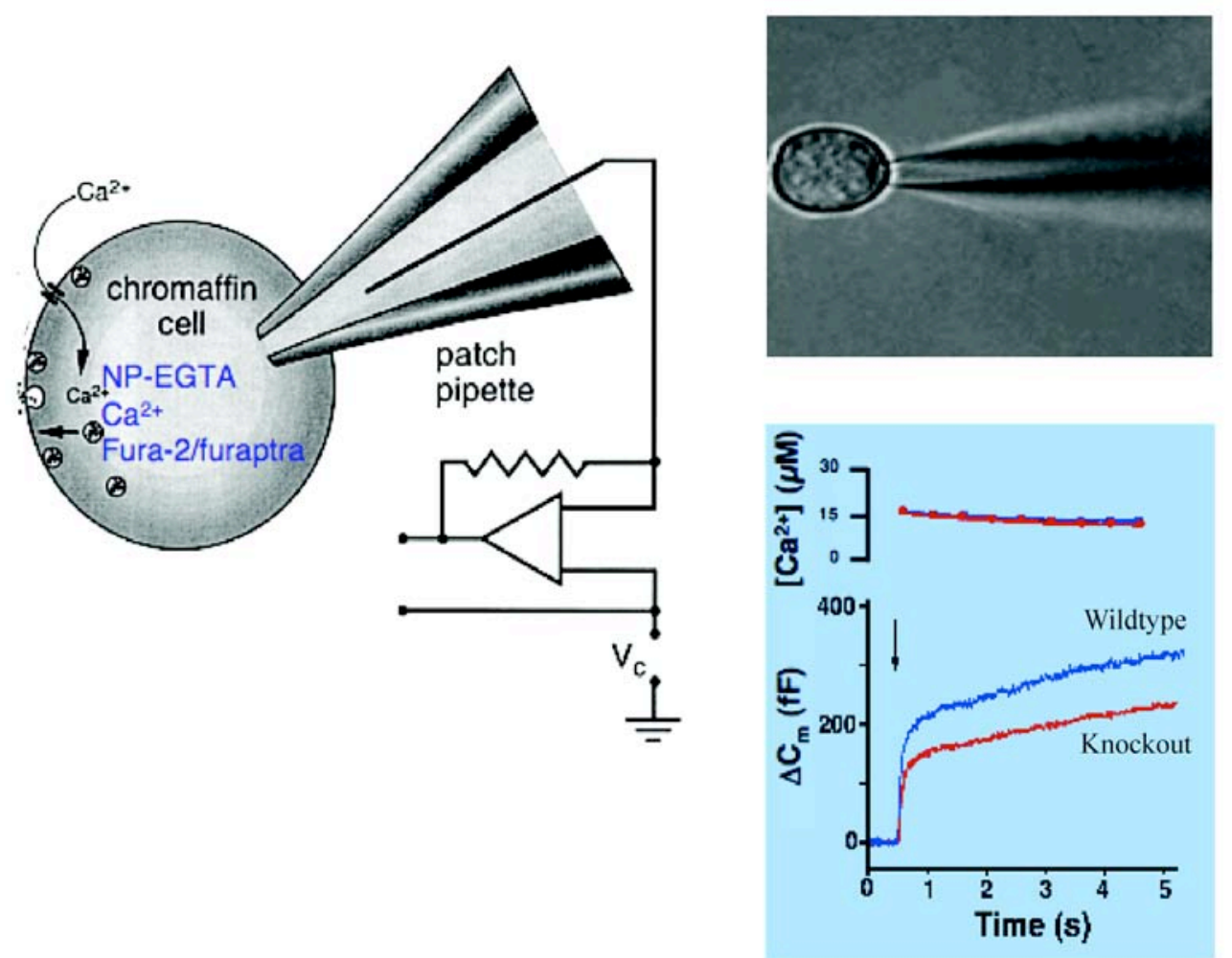

Figure 4. Measuring LDCV Fusion and Exocytosis in Chromaffin Cells.

By UV-flash photolysis of the photolabile $\mathrm{Ca}^{2+}$ chelator NP-EGTA-Ca ${ }^{2+}$ in the cell, the intracellular $\mathrm{Ca}^{2+}$ concentration can be increased in a step-wise fashion to $15-20 \mu \mathrm{M}$ (bottom right panel, top trace). Fusion of LDCVs can be measured by a patch-clamp electrode as an increase in the cell membrane capacitance (bottom right panel, bottom trace). Images are modified from J. Rettig and J. Sørensen, Göttingen.

\subsubsection{The SNARE Core Complex and SNARE-Regulating Proteins}

SNAREs (soluble N-ethylmaleimide sensitive factor attachment protein receptors) are localized to the various intracellular organelles. They comprise a family of mostly membrane-tethered proteins containing a coiled-coil SNARE motif, and they regulate fusion reactions and target specificity in vesicle trafficking. Based on their localization, SNAREs can be classified into vesicle associated v-SNAREs and target-membraneassociated t-SNAREs. The SNARE motifs are homologous 70 -amino acid sequences that can be segregated into four distinct classes, R-, Qa-, Qb-, and Qc-SNARE motifs. Four such motifs, typically one of each type, form a stable trans SNARE complex, a 
four helical bundle that drives the fusion of the resident membranes. Fusion of SVs is mediated by three SNARE core complex component proteins: Syntaxin and SNAP-25 (synaptosome-associated protein of $25 \mathrm{kDa}$ ) on the presynaptic plasma membrane, and Synaptobrevin (also called vesicle-associated membrane protein; VAMP) on the vesicle membrane (Söllner et al., 1993). The core of this complex is formed by the R-SNARE motif of Synaptobrevin, the Qa-SNARE motif of Syntainx 1, and the Qb- and Qc-motifs of SNAP-25. Their association drives the fusion of the SV membrane with the active zone plasma membrane (Figure 2). After fusion, the trimeric complex binds to a complex of the ATPase N-ethylmaleimide-sensitive factor (NSF) and soluble NSF attachment proteins (SNAPs), which disassemble the SNARE complex and make the individual components available for subsequent reuse (Hayashi et al., 1995).

SNARE complexes are essential for fusion of SVs and LDCVs - genetic ablation of synaptic SNAREs in Drosophila, C. elegans, and M. Musculus abolishes evoked neurotransmission (Nonet et al., 1998; Schoch et al., 2001; Schulze et al., 1995; Washbourne et al., 2002). Several proteins are critically involved in the control of SNARE core complex assembly and function. (i) SNARE complex formation is controlled by proteins of the Sec1/Munc18-like (SM) family (Jahn et al., 2003). SM proteins bind to Syntaxin-like SNAREs. Munc18-1, a key SM protein of mammalian that controls synaptic fusion, interacts with a conformation of Syntaxin that is closed and prevented from SNARE complex formation. In addition, Munc18 can bind the Syntaxin N-terminus. One role of Munc18 in neurotransmitter release from SVs and in LDCVs is that of a docking factor that acts prior to SNARE complex assembly. The number of membrane-proximal LDCVs is reduced in chromaffin cells of Munc18-1 deletion mutant mice (Voets et al., 2001). Likewise, docking of SVs at the C. elegans neuromuscular junction is impaired in mutants lacking the Munc18-1 orthologue Unc18 (Weimer et al., 2003). On the other hand, docking of SVs is not altered in 
mammalian Munc18-1 deficient central synapses, although these synapses do not release neurotransmitter (Verhage et al., 2000). (ii) Munc13 and CAPS proteins are essential for SV priming (Varoqueaux et al., 2002; Jockusch et al., 2007). Their role will be discussed in further detail below. (iii) The function of Munc13s is counteracted by Tomosyn, which can act as a scavenger of SNAREs, thus limiting SNARE complex assembly (Wojcik and Brose, 2007). (iv) Complexins bind to the assembled SNARE complex and maintain it in a highly fusogenic state (Brose, 2008). (v) Synaptotagmins act as the $\mathrm{Ca}^{2+}$ sensors of regulated SV and LDCV secretion (Südhof, 2004). Synaptotagmins form a large family of proteins (Craxton, 2004), which contain an Nterminal transmembrane domain, followed by a linker region and two C-terminal $\mathrm{C} 2$ domains that are referred to as $\mathrm{C} 2 \mathrm{~A}$ and $\mathrm{C} 2 \mathrm{~B}$. Synaptotagmin 1 is the family member best characterized. Its $\mathrm{C} 2 \mathrm{~A}$ and $\mathrm{C} 2 \mathrm{~B}$ domains bind $\mathrm{Ca}^{2+}$ and interact with phospholipid membranes in a $\mathrm{Ca}^{2+}$-dependent manner (Bai et al., 2004; Bai and Chapman, 2004; Brose et al., 1992). Synaptotagmin 1 likely acts as a $\mathrm{Ca}^{2+}$-sensor and trigger of fusion by simultaneously binding in a $\mathrm{Ca}^{2+}$-dependent manner to the assembled SNARE complex and the phospholipids of the fusing membranes (Chapman et al., 1995; Kee and Scheller, 1996; Li et al., 1995; Rickman et al., 2003; Wojcik and Brose, 2007), at the same time displacing Complexin from the complex.

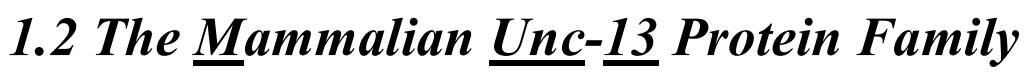

Munc13 proteins are homologues of C. elegans Unc-13, which was initially identified as the product of a gene whose mutation causes unccordinated movements and reduced transmitter release (Brenner, 1974; Hosono and Kamiya, 1991; Brose et al., 1995). Mammals express three closely related Unc-13 homologues, Munc13-1, -2, -3. (Brose et 
al., 1995) and a distantly related variant called Munc13-4 (Koch et al., 2000) (Figure 5). Munc13-1, -2, and -3 are mainly expressed in neurons. In mice and rats, Munc13 expression starts around birth and increases to reach plateau at postnatal days 20-30, when synapse formation is largely complete. Munc13s 1-3 are localized to presynaptic active zones, while Munc13-4 is present mainly in lung and lymphocytes.

Munc13s 1-3 have a complex domain structure with divergent $\mathrm{N}$-termini and conserved C-terminal regions, which contain a $\mathrm{C} 1$ domain that binds diacylglycerol and phorbolesters, two $\mathrm{C} 2$ domains one of which (C2B) binds $\mathrm{Ca}^{2+}$ (Dai et al., 2005; Guan et al., 2008; Lu et al., 2006; Rizo and Rosenmund, 2008), and two Munc13-homology domains that are important for protein function (Stevens et al., 2005; Basu et al., 2005).
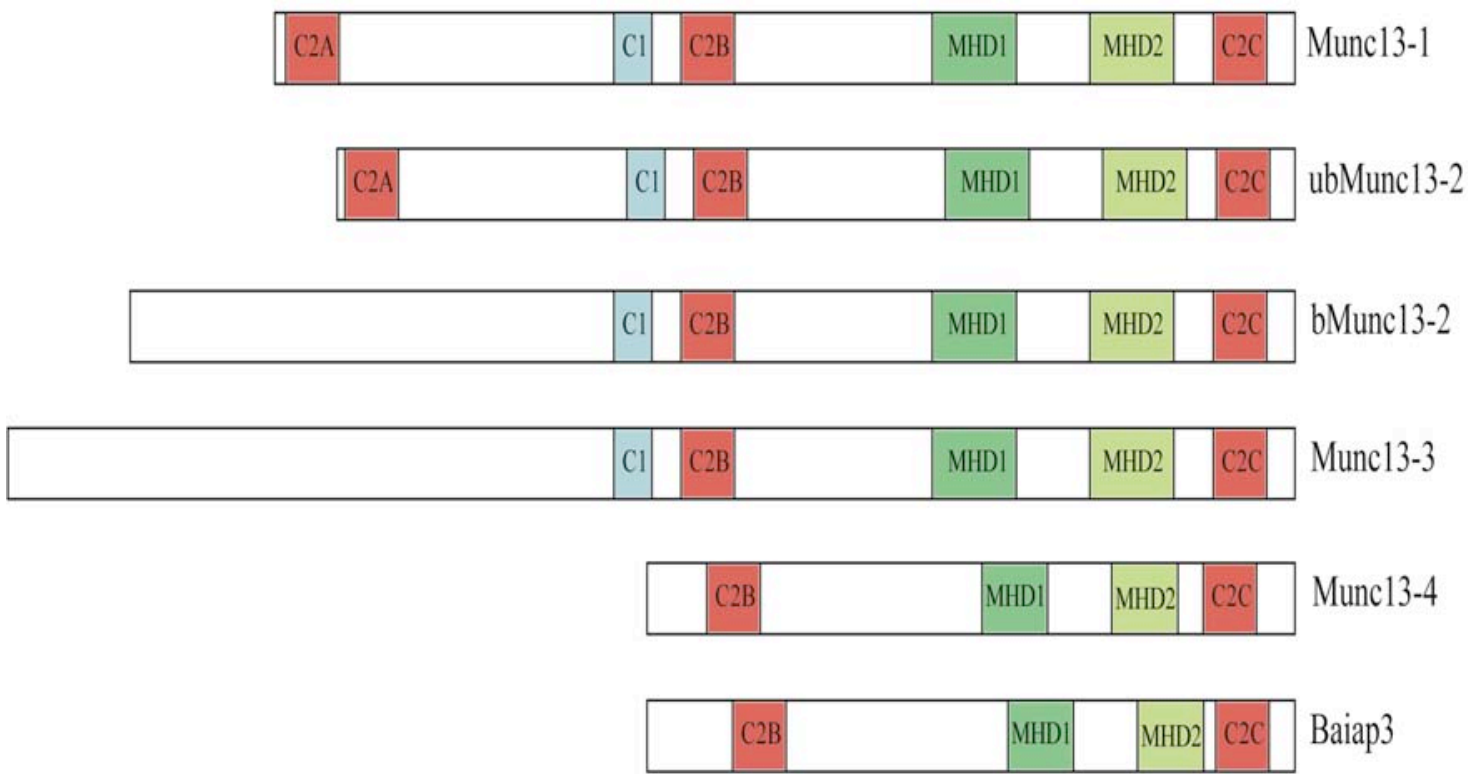

\section{Figure 5. Domain Structure of Munc13s and Baiap3.}

Munc13s contain a C1 domain, two or three C2 domains and two Munc13-homology domains (MHDs). Baiap3 also contains two C2 domains and two MHDs, but lacks the variable N-terminal region found in Munc13-1, -2, and -3. Based on its sequence, Baiap3 is most similar to Munc13-4. 
Munc13-1 is expressed in almost all neurons of the CNS, Munc13-2 is mainly expressed in cortex and hippocampus, and Munc13-3 is mainly found in cerebellum and brainstem (Augustin et al., 1999a). One splice variant of Munc13-2, b-Munc13-2, is brain specific, while a second one, ubMunc13-2, is also found in other tissues (Betz et al., 2001).

Loss of Munc13-1 in mutant mice does not affect synapse, neuron, or brain morphology but causes an almost complete block (90\%) of SV priming in hippocampal glutamatergic neurons and a concomitant almost complete arrest of SV fusion in these cells, while GABAergic neurons are not affected by Munc13-1 deletion (Augustin et al., 1999b). The remaining release in glutamatergic and GABAergic cells of Munc13-1 deficient mice is due to the presence of Munc13-2 and totally eliminated upon the additional deletion of Munc13-2 (Varoqueaux et al., 2002). Similarly, evoked release at cholinergic neuromuscular synapses is almost shut down upon deletion of all three Munc13 genes in mice (Varoqueaux et al., 2005), as is GABAergic and cholinergic transmission at the neuromuscular synapse of unc-13 null-mutant C. elegans (Richmond et al., 1999). Loss of the Drosophila homologue Dunc-13 completely abolishes synaptic transmission at the fly glutamatergic neuromuscular junction (Aravamudan et al., 1999). Munc13s are thought to mediate vesicle priming by binding to the $\mathrm{N}$-terminus of Syntaxin, thereby keeping it in its open conformation which is able to enter SNARE complex formation (Betz et al., 1997; Brose et al., 2000; Richmond et al., 2001). Munc13s are regulated by diacylglycerol through their C1 domains (Betz et al., 1998; Rhee et al., 2002) and by Calmodulin (Junge et al., 2004), and the presynaptic targeting of Munc13-1 and ubMunc13-2 is controlled by the interactions of their respective Ntermini with RIM (Betz et al., 2001; Andrews-Zwilling et al., 2006). As mentioned above, the MHDs of Munc13s and their flanking sequences are essential for the Munc13-mediated priming function (Stevens et al., 2005; Basu et al., 2005). The 
corresponding minimal priming region, called MUN domain, domain binds to membrane-anchored SNARE complexes and to Syntaxin 1-SNAP-25 heterodimers (Guan et al., 2008).

The role of Munc13 proteins in LDCV secretion is less well understood. Overexpression of Munc13-1 in mouse chromaffin cells leads to an increase in secretion as compared with wild type cells. More specifically, the size of the exocytotic burst is increased 3-4 fold, and the sustained component of release is strongly augmented upon Munc13-1 overexpression. Importantly, the overexpression of Munc13-1 does not affect the rate constants of fusion from releasable pools, indicating that Munc13-1 can drive priming of chromaffin secretory granules from a docked to a fusion competent state, which is apparently rate limiting in adrenal chromaffin cells (Ashery et al., 2000). This gain-of-function effect of Munc13-1 overexpression in chromaffin cells requires the two MHDs with the flanking C2C domain and its ability to bind Syntaxin (Stevens et al., 2005). Munc13 deletion mutant chromaffin cells have not been studied so far. However, in C. elegans, Unc-13 does not appear to be necessary for LDCV secretion. Rather, a distant relative of Munc13s, Unc-31/CAPS is necessary for LDCV secretion in $C$. elegans (Speese et al., 2007; Zhou et al., 2007).

\subsection{Munc13-4 and Baiap3/Bap3}

Munc13-4 was identified as a distant Munc13 homologue in protein profile searches for proteins with MHDs (Koch et al., 2000). Together with Baiap3/Bap3, which was identified in the same profile search, it forms a subfamily of Munc13-like molecules, in which the typical Munc13-like domain structure is conserved (Figure 5). Munc13-4 is mainly expressed in lung where it is localized to goblet cells of the bronchial epithelium 
and to alveolar type II cells, which are both cell types with a secretory function, and in lymphocytes (Koch et al., 2000).

Loss-of-function mutations in the human Munc13-4 gene cause familial hemophagocytic lymphohistiocytosis type 3 (FHL3). At the functional level, these mutations appear to cause defective cytolytic granule exocytosis. Further analyses showed that human Munc13-4 is involved in a late step of the cytolytic granule exocytosis pathway, downstream of Rab27a (Feldman et al., 2003). Indeed, Munc13-4 binds directly to Rab27a, whose mutation causes Griscelli Syndrome type 2 (GS2), a genetic disorder involving life-threatening defects of cytotoxic T lymphocytes.

Munc13-4 and Rab27a are highly expressed in cytotoxic T lymphocytes and mast cells, where they colocalize at secretory lysosomes. Overexpression of Munc13-4 enhances degranulation of secretory lysosomes in mast cells, which indicates that it has a positive regulatory role in secretory lysosome fusion (Neeft et al., 2005). Thus, Munc13-4 appears to be essential for the priming of cytolytic granules, much like Munc13s 1-3 mediate priming of SVs.

Baiap3/Bap3 (Brain-specific Angiogenesis Inhibitor 1-Associated Protein 3) is 34\% identical to Munc13-4 (Koch et al., 2000). Baiap3/Bap3 was first identified as an interactor of the cytoplasmic region of BAI 1 (Brain-specific Angiogenesis Inhibitor 1), which is the product of a p53 target-gene, which encodes a seven span transmembrane protein, and which is specifically expressed in brain (Shiratsuchi et al., 1998).

The function of Baiap3/Bap3 is currently unknown. It is expressed predominantly in hypothalamus, amygdala, periaqueductal grey, septum and several brainstem nuclei. Analyses of deletion mutant fragments of Baiap3 showed that the interaction between Baiap3/Bap3 and BAI1 is dependent on the MHDs of Baiap3/Bap3 but not on the flanking C2 domains (Shiratsuchi et al., 1998). Interestingly, the Baiap3/Bap3 interactor BAI1 is distantly related to the $\mathrm{Ca}^{2+}$-independent receptor for $\alpha$-latrotoxin, CIRL) 
which regulates synaptic neurotransmitter release (Krasnoperov et al., 1997; Lelianova et al., 1997).

So far, Baiap3/Bap3 has mostly been studied in the context of cancer development. The Baiap3/Bap3 promoter specifically binds the transcription factor EWS (Ewing's sarcoma)-WT1 (Wilms' tumor suppressor 1), which can transactivate a number of genes implicated in cellular differentiation. Baiap3/Bap3 is expressed in secretory syncytiotrophoblast cells of the placenta and in epithelial cells of the breast and prostate, and it is colocalized with a secreted growth factor within cytoplasmic organelles. Ectopic expression of Baiap3/Bap3 in tumor cells dramatically enhances growth in low serum and colony formation in soft agar assays. Interestingly, the Baiap3/Bap3 gene encodes a transcriptional target of an oncogenic fusion protein and regulates the exocytotic pathway in cancer cell proliferation (Palmer et al., 2002). In summary, the role of Baiap3 may be rate limiting for selected steps in the secretory pathway of specific cell types (Chan and Weber, 2002). However, the exact role of Baiap3/Bap3 in the control of SV or LDCV secretion and its relationship with other members of the Munc13 protein family are unknown. 


\subsection{The Aim of the Present Study: An Analysis of the Role of}

\section{Munc13 Proteins and Baiap3/Bap3 in LDCV Exocytosis}

The present study was performed with the aim to examine the role of Munc13 proteins and their relative Baiap3 in LDCV exocytosis. More specifically, my plan was to study LDCV secretion in mouse chromaffin cells in order to address the following two questions:

1. Do Munc13s regulate LDCV priming? Studies in C. elegans indicated that the nematode Munc13-homlogue Unc-13 specifically regulates SV priming while the CAPS homologue Unc-31 mediates the corresponding priming effect in LDCV fusion (Zhou et al., 2007). These findings supported earlier studies in mammalian systems, which led to the conclusion that CAPS proteins are selectively responsible only for LDCV-mediated exocytosis (e.g. Tandon et al., 1998; Rupnik et al., 2000; Sadakata et al., 2004 and 2007; Speese et al., 2007). However, a recent study in CAPS deficient mice clearly showed that CAPS proteins are absolutely essential for SV-mediated exocytosis (Jockusch et al., 2007), indicating that a restriction of CASPS/Unc-31-dependent regulatory processes to LDCV-mediated secretion may not exist in mammals. In order to complement these findings, my first aim was to test systematically whether in mammals the SV priming proteins Munc13-1, 2, and -3 are also important for LDCV priming.

2. Does Baiap3/Bap3 play a Munc13-related role in LDCV priming? Baiap3/Bap3 is a distant Munc13 homologue of unknown function. In view of its homology with Munc13s and the published literature indicating that Munc13s may not be involved in LDCV secretion, I set out to examine whether Baiap3/Bap3, instead of Munc13s, controls LDCV priming in chromaffin cells. 


\title{
2. Materials and Methods
}

\author{
2.1 Knock Out Mice
}

\subsubsection{Munc13-1, Munc13-2 and Munc13-3 KO Mice}

The Munc13-1, Munc13-2 and Munc13-3 deficient mice used in this study have been described previously (Augustin et al., 1999b; Varoqueaux et al., 2002; Augustin et al., 2001). Chromaffin cells used in this study were cultured from pups on postnatal day 0 (P0) if the mice were deficient for only one Munc13 isoform, whereas in the case of double and triple Munc13-1, -2 and -3 KO mice, cells were cultured on embryonic day 18 (E18). For each experiment WT or heterozygous littermates were used as controls.

PCR Genotyping for Munc13-1

Primer 1 (\#544): 5'-CTTACCCATCTGAGAGCCGGAATTCCA-3'

Primer 2 (\#5216): 5'-CTCCGAGGGGAATGCGCTTCCGTTTCCTG-3'

Primer 3 (\#428): 5'-GAGCGCGCGCGGCGGAGTTGTTGAC-3'

Munc13-1 WT allele; 250 bp and Munc13-1 KO allele; 230 bp

\#: Primer number as designated by the AGCT DNA Core Facility, Max Planck Institute for Experimental Medicine, Germany. 


\begin{tabular}{|c|c|c|c|}
\hline \multicolumn{2}{|l|}{ Reaction Mixture } & \multicolumn{2}{|l|}{ PCR Program } \\
\hline 10X Buffer & $2 \mu 1$ & $94^{\circ} \mathrm{C}$ for $3 \mathrm{~min}$ & - 1 cycle \\
\hline dNTPs & $1 \mu 1$ & $94^{\circ} \mathrm{C}$ for $30 \mathrm{sec}$ & $\longrightarrow$ \\
\hline Primer 1 & $2 \mu 1$ & $60^{\circ} \mathrm{C}$ for $30 \mathrm{sec}$ & 30 cycles \\
\hline Primer 2 & $1 \mu 1$ & $72^{\circ} \mathrm{C}$ for $1 \mathrm{~min}$ & \\
\hline Primer 3 & $1 \mu l$ & $72{ }^{\circ} \mathrm{C}$ for $10 \mathrm{~min}$ & -1 cycle \\
\hline Red Taq & $1 \mu 1$ & $10^{\circ} \mathrm{C}$ for forever & -1 cycle \\
\hline $\mathrm{dH}_{2} \mathrm{O}$ & $11 \mu 1$ & & \\
\hline Total & $19 \mu 1$ & & \\
\hline Template DNA & $1 \mu 1$ & & \\
\hline
\end{tabular}

PCR Genotyping for Munc13-2

Primer 4 (\#1125): 5'-TCTCCACTGCCCCCTTTTACTGT-3'

Primer 5 (\#1124): 5'-TCAAGGGACTGTTCTAGCAATGTT-3'

Primer 6 (\#428): 5'-GAGCGCGCGCGGCGGAGTTGTTGAC-3'

Munc13-2 WT allele; 322 bp and Munc13-2 KO allele; 349 bp

\begin{tabular}{|c|c|c|c|}
\hline Reaction Mixture & & PCR Program & \\
\hline 10X Buffer & $2 \mu 1$ & $94{ }^{\circ} \mathrm{C}$ for $3 \mathrm{~min}$ & - 1 cycle \\
\hline dNTPs & $1 \mu l$ & $94{ }^{\circ} \mathrm{C}$ for $30 \mathrm{sec}$ & - \\
\hline Primer 4 & $2 \mu l$ & $60^{\circ} \mathrm{C}$ for $30 \mathrm{sec}$ & 30 cycles \\
\hline Primer 5 & $1 \mu l$ & $72{ }^{\circ} \mathrm{C}$ for $1 \mathrm{~min}$ & \\
\hline Primer 6 & $1 \mu l$ & $72{ }^{\circ} \mathrm{C}$ for $10 \mathrm{~min}$ & 1 cycle \\
\hline Red Taq & $1 \mu l$ & $10^{\circ} \mathrm{C}$ for forever & -1 cycle \\
\hline $\mathrm{dH}_{2} \mathrm{O}$ & $11 \mu 1$ & & \\
\hline Total & $19 \mu 1$ & & \\
\hline Template DANN & $1 \mu l$ & & \\
\hline
\end{tabular}


PCR Genotyping for Munc13-3

Primer 7 (\#776): 5'-GGCTAGGAAGCAGGTAGTGATGGCTG-3'

Primer 8 (\#775): 5'-GCTTAACTGGAACTCACTGGATGTCAGAG-3'

Primer 9 (\#495): 5'-GACGAGTTCTTCTGAGGGGATCGGC-3'

Primer 10 (\#494): 5'-TACATTAGAGATGATAATTATCACACCCCAAAG-3'

Munc13-3 WT allele; 395 bp, and Munc13-3 KO allele; 410 bp

\begin{tabular}{|c|c|c|c|}
\hline \multicolumn{2}{|l|}{ Reaction Mixture } & \multicolumn{2}{|l|}{ PCR Program } \\
\hline 10X Buffer & $2 \mu 1$ & $94^{\circ} \mathrm{C}$ for $3 \mathrm{~min}$ & - 1 cycle \\
\hline dNTPs & $1 \mu 1$ & $94^{\circ} \mathrm{C}$ for $30 \mathrm{sec}$ & $\square$ \\
\hline Primer 7 & $2 \mu 1$ & $60{ }^{\circ} \mathrm{C}$ for $30 \mathrm{sec}$ & 30 cycles \\
\hline Primer 8 & $1 \mu 1$ & $72^{\circ} \mathrm{C}$ for $1 \mathrm{~min}$ & \\
\hline Primer 9 & $1 \mu 1$ & $72{ }^{\circ} \mathrm{C}$ for $10 \mathrm{~min}$ & - 1 cycle \\
\hline Primer 10 & $1 \mu 1$ & $10^{\circ} \mathrm{C}$ for forever & -1 cycle \\
\hline Red Taq & $1 \mu 1$ & & \\
\hline $\mathrm{dH}_{2} \mathrm{O}$ & $11 \mu 1$ & & \\
\hline Total & $19 \mu 1$ & & \\
\hline Template DNA & $1 \mu 1$ & & \\
\hline
\end{tabular}

\subsubsection{Baiap3/Bap3 KO Mice}

Baiap3 deficient mice were generated by Dr. Iris Augustin by homologous recombination in embryonic stem cells. Briefly, genomic sequences of Baiap3 were subcloned into the pTK-Neo vector. In the targeting vector a $500 \mathrm{bp}$ genomic fragment containing exon 1-3 was replaced by a neomycin resistance gene. The vector also contained two copied of the herpes simplex virus thymide kinase for negative selection. Recombinant stem cell clones were identified by Southern blotting. Two positive clones were injected into mouse blastocytes to obtain highly chimeric mice that transmitted the 
mutant gene through the germ line. Germ line transmission of the mutant gene was confirmed by southern blotting. Subsequent routine genotyping was performed by PCR. Western blot analyses of adult mouse brain homogenates with a Baiap3 specific antiserum directed against the N-terminus (a.a 9-181) or C-terminus (a.a 330-1150) of Baiap3, demonstrated the total absence of Baiap3 in homozygous mutant brain. Chromaffin cells from Baiap3 KO mice were cultured form P0 pups and WT littermates were used as controls.

PCR Genotyping for Baiap3

Primer 11 (\#2862): 5'- CCAGAAATCCGCAGGCAGTCGTCA-3'

Primer 12 (\#2863): 5'- CAAGGCAACCACCAGCCGCATCTA-3'

Primer 13 (\#2935): 5'- GAACACGGCGGCATCAGAGCAG-3'

Baiap3 WT allele; 546 bp and Baiap3 KO allele; 636 bp

$\begin{array}{lll}\text { Reaction Mixture } & & \text { PCR Program } \\ \text { 10X Buffer } & 2 \mu 1 & 94^{\circ} \mathrm{C} \text { for } 1 \mathrm{~min}-1 \text { cycle } \\ \text { dNTPs } & 1 \mu 1 & 94^{\circ} \mathrm{C} \text { for } 1 \mathrm{sec} \\ \text { Primer } 11 & 2 \mu 1 & 60^{\circ} \mathrm{C} \text { for } 30 \mathrm{sec} \\ \text { Primer } 12 & 1 \mu 1 & 72{ }^{\circ} \mathrm{C} \text { for } 30 \mathrm{sec}\end{array}$




\subsection{In Vivo Assays}

\subsubsection{Cell Culture and Transfection}

\subsubsection{Cell Line Culture and Transfection}

The HEK (Human Embryonic Kidney) 293FT cell line, an epithelial line derived from human embryonic kidney cells transformed with the large T-antigen, was used for both in vivo and in vitro binding assays. The cell line was maintained in plastic tissue culture dishes with high-glucose Dulbecco's Modified Eagle's Medium (DMEM) supplemented with $10 \%$ fetal calf serum (FCS) in a $37{ }^{\circ} \mathrm{C}$ humid incubator with $5 \%$ ambient $\mathrm{CO}_{2}$. The selection agent G418 (Geneticin) was added to complete DMEM medium of HEK293FT cells at a concentration of $500 \mu \mathrm{g} / \mathrm{ml}$. Passaging was performed using standard procedures of trypsin mediated dislodgment of confluent cultures.

1. For thawing cells, pre-warm the complete DMEM medium without G418

2. Frozen vial from Liquid Nitrogen Tank, thaw the vial by gently shaking in a $37^{\circ} \mathrm{C}$ water-bath

3. Transfer the cells into $10 \mathrm{ml}$ pre-warmed complete DMEM medium without Geneticin in a $50 \mathrm{ml}$ falcon tube and mix slowly

4. Centrifuge for $3 \mathrm{~min}$ at $800 \mathrm{rpm}$

5. Carefully discard supernatant

6. Wash the pellet with PBS and centrifuge a second time

7. Resuspend the cells in $10 \mathrm{ml}$ of pre-warmed medium

8. Transfer the suspended cells into T75 flask and incubate at $37{ }^{\circ} \mathrm{C}$ 
9. One day before cells reach $90 \%$ confluency, discard the medium from the T75 flask

10. Add $5 \mathrm{ml} 0.05 \%$ Trypsin and incubate for $5 \mathrm{~min}$ at $37^{\circ} \mathrm{C}$

11. Add $10 \mathrm{ml}$ complete DMEM medium and triturate cells thoroughly

12. Centrifuge for $3 \mathrm{~min}$ at $800 \mathrm{rpm}$

13. Carefully discard supernatant

14. Wash the pellet with PBS and centrifuge again

15. Resuspend cells in $10 \mathrm{ml}$ of pre-warmed medium

16. Transfer suspended cells into $3 \mathrm{X} \mathrm{T75}$ flask and incubate at $37^{\circ} \mathrm{C}$

Transfections were performed using Lipofectamine 2000 by following standard procedures.

1. For transfection of HEK293FT cells with either pMYC-Baiap3 full-length or pCDNA3-Munc13-1 full-length constructs, plate 6-7 X $10^{5}$ cells in $15 \mathrm{ml}$ of complete DMEM medium (for $15 \mathrm{~cm}$ dish format). Cells will be $85-90 \%$ confluent at the time of transfection

2. For transfection samples, dilute $30 \mu \mathrm{g}$ of DNA (each construct) in $1.5 \mathrm{ml}$ of Opti-MEM I without serum and gently mix.

3. Mix Lipofectamine 2000 gently before use, dilute $60 \mu \mathrm{l}$ of Lipofectamine 2000 in $1.5 \mathrm{ml}$ Opti-MEM I and incubate for $5 \mathrm{~min}$ at $\mathrm{RT}$

4. Combine the diluted DNA with the diluted Lipofectamine 2000. Mix gently and incubate for $20 \mathrm{~min}$ at $\mathrm{RT}$

5. Add the DNA-Lipofectamine complexes to each dish

6. Incubate the cells at $37{ }^{\circ} \mathrm{C}$ in a $\mathrm{CO}_{2}$ incubator for $30 \mathrm{hr}$ prior to testing for cosedimentation 
Complete DMEM medium: DMEM

\author{
$10 \%$ FCS \\ $0.1 \mathrm{mM}$ Non-Essential Amino Acids \\ 2 mM L-glutamine \\ $500 \mu \mathrm{g} / \mathrm{ml} \mathrm{G} 418$ \\ $1 \%$ Penicillin/Streptomycin
}

\title{
2.2.1.2 Mouse Chromaffin Cells Culture
}

Embryonic (E18) and/or postnatal (P0) adrenal glands were dissected and chromaffin cells prepared by digestion with Papain solution. The adrenal glands were incubated with $400 \mu \mathrm{l}$ papain solution at $37^{\circ} \mathrm{C}$ for $30 \mathrm{~min}$ in Eppendorf Thermocycler $(500 \mathrm{rpm})$, followed by addition of $400 \mu \mathrm{l}$ stop solution and incubation for $15 \mathrm{~min}$. The solution was then replaced by $500 \mu 1$ complete NBA (Neurobasal-A) medium. The adrenal glands were gently opened before digestion, and triturated gently through a $10 \mu$ pipette tip. The entire cell suspension obtained from two glands (one animal) was plated on a sterile coverslip in a 6-well plate. The cells were incubated at $37{ }^{\circ} \mathrm{C}$ and $5 \% \mathrm{CO}_{2}$ and used within 2 days after plating.

$\begin{array}{ll}\text { Complete NBA medium: } & 500 \mathrm{ml} \text { NBA medium } \\ & 10 \mathrm{ml} \mathrm{B} 27 \\ & 5 \mathrm{ml} \text { Glutamax } \\ & 1 \mathrm{ml} \text { Penicillin/Streptomycin } \\ & 250 \mathrm{ml} \text { DMEM medium } \\ & 50 \mathrm{mg} \text { L-Cystein } \\ & 2.5 \mathrm{ml} \mathrm{0.1M} \mathrm{CaCl} \\ & 2.5 \mathrm{ml} 50 \mathrm{mM} \text { EDTA } \\ & 20 \mathrm{units} / \mathrm{ml} \text { papain } \\ & 225 \mathrm{ml} \text { DMEM medium } \\ & 25 \mathrm{ml} \text { heat inactivated FCS } \\ & 625 \mathrm{mg} \text { Albumin } \\ & 625 \mathrm{mg} \text { Trypsin inhibitor }\end{array}$




\subsubsection{SFV Preparation and Infection}

SFV1 constructs expressing a Munc13-1-EGFP fusion protein have been described previously (Ashery et al., 2000). A Baiap3-IRES-EGFP construct was sub-cloned bluntended into the SmaI site of the pSFV1 polylinker. Following linearization with SpeI, cDNAs of pSFV-Baiap3-IRES-EGFP, pSFV-Munc13-1-EGFP, and pSFV-helper1 were transcribed in vitro with SP6 RNA polymerase. BHK21 cells, derived from hamster kidney, were then transfected by electroporation $(400 \mathrm{~V}, 975 \mu \mathrm{F})$ with a combination of $10 \mu \mathrm{g}$ of each constructs and incubated at $37^{\circ} \mathrm{C}, 5 \% \mathrm{CO}_{2}$ for $24 \mathrm{hr}$. Following this incubation, the supernatant was collected and clarified from cell debris by low speed centrifugation. The supernatant containing the inactivated virus was snap-frozen in 450 $\mu \mathrm{l}$ aliquots and stored at $-80{ }^{\circ} \mathrm{C}$. To test the virus titer, an aliquot was thawed and activated. BHK21 cells were then infected with various dilutions of the activated virus, and the infection efficiency was determined by assessing EGFP fluorescence. Four hundred and fifty microliters of frozen virus were thawed and diluted 1:1 with optiMEM medium with $2.5 \%$ FCS. To activate the virus, $110 \mu$ l Chymotrypsin was added and incubated for $35 \mathrm{~min}$ at RT. In order to inactivate the chymotrypsin, $110 \mu \mathrm{l}$ Aprotinin was added, incubation continued for an additional 5 min at RT. Infection was performed on cultured cells $24 \mathrm{hr}$ after preparation according to published protocols (Ashery et al., 1999).

To generate viral RNA for electroporation of BHK21 cells:

1. Linearize DNA with SpeI enzyme

2. Linearized DNA purification using phenol-chloroform extraction

3. Precipitate DNA using $3 \mathrm{M}$ sodium acetate after purification

4. In vitro transcription using SP6 trancription Kit 
5. RNA purification using phenol-chloroform extraction

6. Precipitate RNA using $3 \mathrm{M}$ sodium acetate after purification

7. Check RNA on formaldehyde-agarose gel

8. Quantification of RNA concentration

9. Transfection with BHK21 cells using electroporation

10. Culture BHK21 cells for 2 days and then harvest the inactive virus

11. Make $450 \mu \mathrm{l}$ aliquots into cryotubes and freeze in liquid nitrogen

12. Store at $-80{ }^{\circ} \mathrm{C}$ until use

To activate the SFV:

1. Take one $450 \mu \mathrm{l}$ virus aliquot and thaw

2. Add $450 \mu 1$ BHK21 cell medium

3. Add $110 \mu 1$ Chymotrypsin and mix and incubate for $35 \mathrm{~min}$ at RT

4. Add $110 \mu \mathrm{l}$ Aprotinin and mix and incubate for $5 \mathrm{~min}$ at RT

5. Store at $4{ }^{\circ} \mathrm{C}$

$\begin{array}{ll}\text { DEPC-treated distilled water : } & 0.1 \% \mathrm{DEPC} \text { (under hood) in } \mathrm{dH}_{2} \mathrm{O} \\ & \text { Stir for } 2 \mathrm{hr} \text { under hood and autoclave } \\ \text { 5X MOPS Buffer: } & 0.1 \mathrm{M} \text { MOPS } \\ & 40 \mathrm{mM} \text { sodium-acetate } \\ & 5 \mathrm{mM} \text { EDTA (pH 8.0) } \\ & 20.4 \mathrm{~g} \text { of Sodium acetate trihydrate } \\ \text { 3M Sodium Acetate: } & \text { Adjust to pH } 5.8 \\ & 1 \mathrm{X} \text { MOPS } \\ \text { RNA gel loading buffer : } & 6.5 \% \text { Formaldehyde } \\ & 50 \% \text { Formamide } \\ & 5 \% \text { Glycerin } \\ & 0.1 \mathrm{mM} \text { EDTA } \\ & 0.025 \% \text { Bromophenol Blue }\end{array}$


BHK Cell Medium :

(for growth)

BHK Cell Medium :

(for electroporation)

Chymotrypsin:

Aprotinin:
$500 \mathrm{ml}$ DMEM medium

$12.5 \%$ FCS

$1 \mathrm{ml}$ Penicillin/Streptomycin

$500 \mathrm{ml}$ NBA medium

$10 \mathrm{ml} \mathrm{B} 27$

$1 \mathrm{ml}$ Penicillin/Streptomycin

$1 \mathrm{ml}$ Glutamax

$2 \mathrm{mg} / \mathrm{ml}$

$6 \mathrm{mg} / \mathrm{ml}$

\subsubsection{Protein Extraction from Whole Brain and Adrenal Gland}

Both whole brain and adrenal gland were taken from WT and Baiap3 KO mice and homogenized with a Glass-Teflon-Homogenizer in $4{ }^{\circ} \mathrm{C}$ in Lysis buffer. Total protein concentration was determined by a BCA protein assay and adjusted to $1-2 \mathrm{mg} / \mathrm{ml}$ in Sample Buffer (1x Laemmli Buffer). Prepare the samples for loading by heating them to $100{ }^{\circ} \mathrm{C}$ for $5 \mathrm{~min}$ in Sample Buffer to denature the proteins.

Lysis Buffer:
\[ \begin{array}{l}320 \mathrm{mM} \text { Sucrose } \\ 150 \mathrm{mM} \mathrm{NaCl} \\ 1 \mathrm{mM} \text { EGTA }(\mathrm{pH} 8.0) \\ 0.2 \mathrm{mM} \text { PMSF } \\ 1 \mu \mathrm{g} / \mathrm{ml} \text { Aprotinin } \\ 1 \mu \mathrm{g} / \mathrm{ml} \text { Leupeptin } \\ 10 \% \text { SDS } \\ 140 \mathrm{mM} \text { Tris/HCl (pH 6.8) } \\ 3 \text { mM EDTA } \\ 30 \% \text { Glycerol } \\ 0.1 \% \text { Bromophenol Blue } \\ 150 \mathrm{mM} \text { DTT before use }\end{array} \]




\subsection{In Vitro Assays}

\subsubsection{Construct Subcloning}

\subsubsection{Restriction Enzyme and Purification}

For the construction of some constructs the gene of interest was amplified by PCR and subsequently digested with the appropriate restriction enzymes. Digested DNA fragments were purified by using phenol-chloroform extraction before subcloning using the following procedures:

1. Amplify DNA and digest with the appropriate restriction enzymes

2. To purify of the DNA, add $200 \mu$ Phenol-chloroform-isoamylalcohol (25:24:1) ( $\mathrm{pH}$ 7.5-8 for DNA; $\mathrm{pH}$ 4-6 for RNA). Mix by pipetting up and down

3. Add $200 \mu 1$ Chloroform and vortex thoroughly

4. Centrifuge at $15000 \mathrm{rpm}$ for $5 \mathrm{~min}$ (DNA is in upper phase)

5. Transfer the supernatant into new eppendorf tube

6. Add $200 \mu 1$ chloroform and mix with vortexer

7. Centrifuge at $15000 \mathrm{rpm}$ for $2 \mathrm{~min}$

8. Transfer the supernatant into new eppendorf tube

9. Add $1 / 10$ volume of $3 \mathrm{M}$ Ammonium-acetate

10. Add 2.5 volume of $100 \%$ cooled $\mathrm{EtOH}$ and mix

11. Incubate at $-20{ }^{\circ} \mathrm{C}$ for $\mathrm{ON}$

12. Centrifuge at $15000 \mathrm{rpm}$ for $30 \mathrm{~min}$

13. Wash the pellet with $-70 \%$ cooled $\mathrm{EtOH}$

14. Centrifuge at $15000 \mathrm{rpm}$ for $10 \mathrm{~min}$ 
15. Carefully remove supernatant and dry the pellet

16. Add $50 \mu \mathrm{ld} \mathrm{d}_{2} \mathrm{O}$ to resuspend and quantify

\subsubsection{Dephosphorylation, Ligation and DNA-sequencing}

Prior to ligation of insert DNA and vector DNA, the 5' ends of the vector were dephosphorlyated by Shrimp Alkaline Phosphatase. Ligation was performed using T4 DNA ligase. After transformation, plasmid DNA was prepared from cultures grown from colonies, analyzed by restriction digests and plasmid DNA from selected clones was sequenced by the Applied Biosystems 373 DNA sequencer by the DNA core facility.

1. For dephosphorylation, add $2.5 \mu \mathrm{l}$ dephosphorylation buffer and $2 \mu 1$ phosphatase in $20.5 \mu 1$ purified DNA

2. Incubate for $10 \mathrm{~min}$ (for sticky ended) or $1 \mathrm{hr}$ (for blunt ended) at $37^{\circ} \mathrm{C}$

3. Inactivate the Shrimp Alkaline Phosphatase for 15 min at $65^{\circ} \mathrm{C}$

4. For the ligation reaction, a 1:5 to 3:8 (vector: insert) ratio is usually used and ligations are placed in $4{ }^{\circ} \mathrm{C}$ water-bath that warms up to $15^{\circ} \mathrm{C} \mathrm{ON}$

5. Transformation into E.coli

\subsubsection{Western Blotting}

\subsubsection{SDS gel Electrophoresis of Proteins}

In order to investigate subunit compositions and to verify homogeneity of protein samples, electrophoresis is used to separate complex mixtures of proteins. Proteins 
migrate in response to an electrical field through pores in the gel matrix. The combination of gel pore size and protein size and charge determines the migration rate of the proteins. SDS-PAGE is an anionic system due to the negatively charged SDS.

1. Pour gel of appropriate polyacrylamide concentration, depending on molecular weight of the protein of interest

2. Mount the gel in the electrophoresis apparatus and fill with running buffer (1X $\mathrm{RB})$

3. Load the prepared samples into the wells

4. Attach the electrophoresis apparatus to an electric power supply. Apply a current of $25 \mathrm{~mA}$ and $50 \mathrm{~mA}$ for one and two gels, respectively

5. After running the gel, place the polyacrylamide gel in a plastic container for either coomassie staining or blot transfer to membranes

$\begin{array}{ll}\text { Stacking gel: } & 1 \mathrm{M} \text { Tris- } \mathrm{HCl}(\mathrm{pH} 6.8) \\ \text { Separating gel: } & 1.5 \mathrm{M} \text { Tris-Hcl }(\mathrm{pH} 8.8) \\ \text { Acrylamide/Bisacrylaminde: } & 30 \% \text { Acrylamid/Bis }(37.5: 1) \\ \text { SDS: } & 10 \% \text { Stock solution } \\ \text { APS } & 10 \% \text { Stock solution } \\ \text { TEMED: } & \text { Solution from SERVA } \\ \text { 10X RB: } & 250 \mathrm{mM} \text { Tris } \\ & 2.5 \mathrm{M} \text { Glycine }(\mathrm{pH} 8.3) \\ & 1 \% \mathrm{SDA}\end{array}$

Separating gels

$7.5 \%$ gel: $>100 \mathrm{kDa}$

$10 \%$ gel: $60 \sim 130 \mathrm{kDa}$

$13 \%$ gel: $20 \sim 80 \mathrm{kDa}$

$15 \%$ gel: $<50 \mathrm{kDa}$

\subsubsection{Coomassie Blue Staining}

An easy and rapid detection method for proteins in gel is to perform a coomassie blue staining of the polyacrylamide gel. It is based on nonspecific binding of the dye coomassie brilliant blue R250 to proteins. The detection limit is 0.3 to $1 \mu \mathrm{g} /$ protein band. 
1. Place the polyacrylamide gel in a plastic container and cover it with 5 volumes of Coomassie staining solution A.

2. Incubate for $1 \mathrm{~min}$ at $100{ }^{\circ} \mathrm{C}$ using Microwave

3. Remove solution A and add Coomassie staining solution B. Incubate for $1 \mathrm{~min}$ at $100{ }^{\circ} \mathrm{C}$ using Microwave

4. Remove solution B and add Coomassie staining solution C. Incubate for $1 \mathrm{~min}$ at $100{ }^{\circ} \mathrm{C}$ using Microwave

5. Remove solution $\mathrm{C}$ and add Coomassie staining solution $\mathrm{D}$. Incubate for $1 \mathrm{~min}$ at $100{ }^{\circ} \mathrm{C}$ using Microwave

6. Pour out Coomassie staining solution D. Keep the gel at RT

$\begin{array}{ll}\text { Coomassie staining solution A: } & 0.15 \% \text { Coomassie Brillant Blue R25 } \\ & 25 \% \text { Isopropanol } \\ & 10 \% \text { Acetic Acid } \\ & 0.015 \% \text { Coomassie Brillant Blue R25 } \\ & 10 \% \text { Isopropanol } \\ \text { Coomassie staining solution B: } & 10 \% \text { Acetic Acid } \\ & 0.006 \% \text { Coomassie Brillant Blue R25 } \\ \text { Coomassie staining solution C: } & 10 \% \text { Acetic Acid } \\ & 10 \% \text { Acetic Acid }\end{array}$

\subsubsection{Blot Transfer of Protein Gels to Membranes}

The membranes used for the electrophoretic transfer were manufactured from nitrocellulose. In this procedure, blotting is performed in a tank of buffer with the gel in a vertical orientation, completely submerged between two large electrode panels as follows: 
1. Assemble transfer sandwich; one plastic support, one porous pad, two pieces of Whatman paper, nitrocellulose, gel, two pieces of Whatman paper, one porous pad, and a plastic support. The transfer cassette should be assembled under buffer to avoid trapping of air bubbles

2. Fill tank with transfer buffer and place the sandwich into electroblotting apparatus. Transfer is achieved by applying a current of $40 \mathrm{~mA}$ for $16 \mathrm{hr}$ at $4{ }^{\circ} \mathrm{C}$ in a cold room

Transfer Buffer:

$25 \mathrm{mM}$ tris- $\mathrm{HCl}(\mathrm{pH} 8.3)$

190 mM Glycine

$20 \%$ Methanol

\subsubsection{Immunoblotting with ECL (Enhanced Chemiluminescence)}

ECL uses the HRP (hydrogen peroxide) catalyzed oxidation of luminol in alkaline conditions. Immediately following oxidation, the luminol is in an excited state which then decays to ground state via a light emitting pathway. ECL is achieved by performing the oxidation of luminol by the HRP in the presence of chemical enhancers such as phenols. This increases the light output approximately 1000 fold and extends the time of light emission. The maximum light emission is at a wavelength of $428 \mathrm{~nm}$, which can be detected by a short exposure to blue-light sensitive autoradiography film. The detection limit of the ECL system is less than 1 picogram (pg) of antigen Procedures used were as follows:

1. Pour $10 \mathrm{ml}$ of Buffer A onto membrane and incubate for $1 \mathrm{hr}$ at $\mathrm{RT}$ or for $\mathrm{ON}$ at $4{ }^{\circ} \mathrm{C}$ on an orbital shaker to block non-specific binding 
2. Dilute the primary antibody in Buffer A and incubate the membrane for $1 \mathrm{hr}$ at RT

3. Wash the membrane three times for $15 \mathrm{~min}$ in Buffer B at RT

4. Dilute the secondary antibody in Buffer A and incubate the membrane for $1 \mathrm{hr}$ at RT

5. Wash the membrane three times for 15 min in Buffer B at RT

6. Wash the membrane three times for $15 \mathrm{~min}$ in Buffer $\mathrm{C}$ at RT

7. Wash the membrane three times for $15 \mathrm{~min}$ in Buffer D at RT

8. Mix an equal volume of ECL detection solution 1 with detection solution 2 to give sufficient volume in order to cover the membrane

9. Incubate for $1 \mathrm{~min}$ at RT with mixed ECL solution

10. Drain off excess detection reagent and cover the filter with a copier transparency

11. Check the signal by exposing the membrane to an autoradiography film in a dark room

$\begin{array}{ll}\text { 10X Transfer Buffer: } & 1.92 \mathrm{M} \text { Glycine } \\ & 250 \mathrm{mM} \text { Tris } \\ \text { 10X TBS: } & 1.37 \mathrm{M} \mathrm{NaCl} \\ & 200 \mathrm{mM} \text { Tris-HCl, pH } 7.6 \\ \text { Tween 20 stock solution: } & 10 \% \text { Tween } 20 \\ \text { Buffer A: } & 5 \% \text { goat serum } \\ & 5 \% \text { milk powder } \\ & 0.1 \% \text { Tween } 20 \\ & 1 X \text { TBS } \\ \text { Buffer B: } & 5 \% \text { milk powder } \\ & 0.1 \% \text { Tween } 20 \\ \text { Buffer C: } & 1 X \text { TBS } \\ \text { Buffer D: } & 0.1 \% \text { Tween } 20 \\ & 1 X \text { TBS } \\ & 1 X \text { TBS }\end{array}$




\subsubsection{Northern Blotting}

\subsubsection{RNA Extraction}

To check the expression level of Baiap3 RNA in WT and Baiap3 KO mice, total RNA was isolated from littermates as follows:

1. Homogenize whole brain from WT and Baiap3 KO mice in Trizol reagent using a Glass-teflon homogenizer

2. Store the homogenate for $10 \mathrm{~min}$ at $\mathrm{RT}$

3. Add chloroform and shake vigorously

4. Store the mixture at RT for $15 \mathrm{~min}$ and centrifuge at $15000 \mathrm{rpm}$ for $15 \mathrm{~min}$ at $4^{\circ} \mathrm{C}$

5. RNA remains exclusively in the aqueous phase and is transferred into a new tube

6. Add isopropanol and mix vigorously

7. Store the mixture at RT for $10 \mathrm{~min}$ and centrifuge at $15000 \mathrm{rpm}$ for $10 \mathrm{~min}$ at $4^{\circ} \mathrm{C}$

8. Remove the supernatant and wash the RNA pellet with $75 \% \mathrm{EtOH}$

9. Centrifuge at $15000 \mathrm{rpm}$ for $5 \mathrm{~min}$ at $4{ }^{\circ} \mathrm{C}$

10. Briefly dry and resuspend RNA pellet with DEPC-water

\subsubsection{Blotting}

The RNA extracted from whole brain of WT and Baiap3 KO littermates was used to detect Baiap3 RNA using a specific probe corresponding to a region of the gene that is not deleted in the Baiap3 KO (a.a 330-1150). RNA is transferred from an agarose gel to 
a Hybond+ (nucleic acid transfer) membrane by capillary transfer. The blots are analyzed by hybridization analysis with a radioactively labeled DNA probe as follows:

1. Prepare RNA samples with 10X MOPS, 12.3 M formaldehyde, and formamide

2. Incubate for $15 \mathrm{~min}$ at $55^{\circ} \mathrm{C}$ and add formaldehyde loading buffer

3. Load the prepared RNA samples onto a formaldehyde agarose gel

4. Run the gel at $80 \mathrm{~V}$ for $4 \mathrm{hr}$ in $1 \mathrm{X}$ MOPS

5. Transfer the gel into a new plastic container with 1L 20X SSC and soak for $45 \mathrm{~min}$

6. For blot, Cut three pieces of $3 \mathrm{M}$ paper and the Hybond+ (nucleic acid transfer) membrane to cover the exposed surface of the gel

7. Incubate for overnight in $0.4 \mathrm{~N} \mathrm{NaOH}$

8. Wash the membrane with $1 \mathrm{X}$ SSC until the $\mathrm{pH}$ reaches 7.5 and dry the membrane

9. Cross link the RNA to the membrane with UV light $\left(1 \mathrm{~J} / \mathrm{Cm}^{2}\right)$

10. Pre-wet the membrane with 2 XSSC and place in hybridization bottle, add hybridization solution and incubate at $65^{\circ} \mathrm{C}$ for $30 \mathrm{~min}$

11. Prepare labeled probe with ${ }^{32} \mathrm{PdCTP}$

$$
\begin{array}{lr}
25 \mathrm{ng} \text { of DNA } & 1 \mu \mathrm{l} \\
\mathrm{dH}_{2} \mathrm{O} & 23 \mu \mathrm{l} \\
& \\
\text { Random primer } & 10 \mu \mathrm{l}
\end{array}
$$

12. Incubate for $5 \mathrm{~min}$ at $100{ }^{\circ} \mathrm{C}$

13. Add $10 \mu 15 \mathrm{X}$ buffer and $5 \mu 1^{32} \mathrm{PdCTP}$ and 1 ul Exo-Klenow and incubate for 10 $\min$ at $37^{\circ} \mathrm{C}$ 
14. Add $2 \mu 1$ Stop mix and purify the labeled probe with Bio-Spin 6 column and Incubate for $6 \mathrm{~min}$ at $100^{\circ} \mathrm{C}$

15. Store the probe on ice for $10 \mathrm{~min}$

16. Add labeled probe to the membrane and incubate $\mathrm{ON}$ at $65{ }^{\circ} \mathrm{C}$

17. Wash the membrane with $2 \mathrm{X} \mathrm{SSC}+0.1 \% \mathrm{SDS}$ at RT for $20 \mathrm{~min}$

18. Wash the membrane with $1 \mathrm{X} \mathrm{SSC}+0.1 \% \mathrm{SDS}$ at $65{ }^{\circ} \mathrm{C}$ for $20 \mathrm{~min}$

19. Wash the membrane with $0.5 \mathrm{X} \mathrm{SSC}+0.1 \% \mathrm{SDS}$ at $68{ }^{\circ} \mathrm{C}$ for $30 \mathrm{~min}$

20. Check the radioisotope activity and wash until counts are below 100

21. Expose the membrane with film at $-80{ }^{\circ} \mathrm{C}$ for 3 days

\begin{tabular}{|c|c|}
\hline \multirow[t]{3}{*}{ 10X MOPS: } & 0.4 M MOPS (pH7.0) \\
\hline & $0.1 \mathrm{M}$ sodium acetate \\
\hline & $0.01 \mathrm{M}$ EDTA \\
\hline \multirow[t]{2}{*}{ 20X SSC: (pH7.0) } & $3 \mathrm{M} \mathrm{NaCl}$ \\
\hline & $0.3 \mathrm{M} \mathrm{Na}_{3}$ citrate $2 \mathrm{H}_{2} \mathrm{O}$ \\
\hline \multirow[t]{4}{*}{ Formaldehyde loading buffer: } & 1 mM EDTA (pH8.0) \\
\hline & $0.25 \%$ bromophenol blue \\
\hline & $0.25 \%$ xylene cyanol \\
\hline & $50 \%$ glycerol \\
\hline \multirow[t]{3}{*}{ Formaldehyde gel $(100 \mathrm{ml})$ : } & $1 \mathrm{~g}$ Agarose in $72 \mathrm{ml} \mathrm{dH_{2 } \mathrm { O }}$ \\
\hline & $10 \mathrm{ml}$ 10XMOPS \\
\hline & 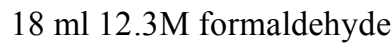 \\
\hline
\end{tabular}

\subsubsection{Expression of GST Fusion Proteins}

In order to express with either Munc13-1 or Sytaxin 1A (a.a 1-256) or Baiap3-MHDs (a.a 330-1150) fusion proteins with GST, BL21DE3 E.coli was subjected to electroporation-mediated plasmid transformation with the respective constructs in pGEX-KG. GST-fusion proteins were prepared by follows; 
1. Inoculate one colony from LB- ampicillin plates with either GST-Munc13-1 or GST-Syntaxin 1A (a.a 1-256) or Baiap3-MHDs (a.a 330-1150) into individual 5 $\mathrm{ml}$ of LB broth containing ampicillin and grow $\mathrm{ON}$ at $37^{\circ} \mathrm{C}$ with shaking.

2. Inoculate $1 \mathrm{~L}$ of $\mathrm{LB}$ with $5 \mathrm{ml}$ from step 1

3. Grow at $37^{\circ} \mathrm{C}$ with shaking for $4 \mathrm{hr}$

4. Induce expression of the protein by adding $0.3 \mathrm{mM} \mathrm{IPTG}$ and incubate for $4 \mathrm{hr}$ at $25{ }^{\circ} \mathrm{C}$ with shaking

5. Centrifuge the culture at $3500 \mathrm{~g}$ for $20 \mathrm{~min}$ at $4{ }^{\circ} \mathrm{C}$

6. Discard the supernatant and resuspend the pellet in $20 \mathrm{ml}$ PBS with protease inhibitors

7. Add Lysozyme and incubate for $10 \mathrm{~min}$ at RT

8. Sonicate the bacterial suspension on ice, three times in short $30 \mathrm{sec}$ bursts

9. Add $1 \%$ Sodium cholate and incubate for $10 \mathrm{~min}$ at $4{ }^{\circ} \mathrm{C}$ with shaking

10. Centrifuge the lysate at $15000 \mathrm{~g}$ for $15 \mathrm{~min}$ at $4{ }^{\circ} \mathrm{C}$

11. Transfer the supernatant to a fresh tube

12. Add $1 \mathrm{ml}$ of a 50:50 slurry of Glutathione-Sepharose 4B beads in lysis buffer and incubate for $\mathrm{ON}$ at $4{ }^{\circ} \mathrm{C}$

13. Centrifuge at $750 \mathrm{~g}$ for $5 \mathrm{~min}$ at $4{ }^{\circ} \mathrm{C}$ to pellet the beads

14. Wash the beads four times in $5 \mathrm{ml}$ of cold wash buffer

15. The fusion protein should be stored on the beads at $4{ }^{\circ} \mathrm{C}$

$\begin{array}{ll}\text { Ampicillin Solution: } & 20 \mathrm{mg} / \mathrm{ml} \\ \text { Kanamycin Solution: } & 10 \mathrm{mg} / \mathrm{ml} \\ \text { LB-Medium: } & 10 \mathrm{~g} \mathrm{NaCl} \\ & 10 \mathrm{~g} \mathrm{Bacto-Trypton} \\ & 5 \mathrm{~g} \mathrm{Bacto}-\text { Yeast-Extract } \\ & \text { In } 1 \mathrm{~L} \mathrm{d \textrm {H } _ { 2 }} \mathrm{O} \text { and Autoclave }\end{array}$




$\begin{array}{ll}\text { LB-Plate: } & 15 \mathrm{~g} \text { Bacto-Agar } \\ & \text { In } 1 \mathrm{~L} \mathrm{LB} \text { Medium } \\ & \text { appropriate antibiotic selection } \\ & 242 \mathrm{~g} \text { Tris Base } \\ & 57.1 \mathrm{ml} \text { Acetic acid } \\ & 100 \mathrm{ml} 0.5 \mathrm{M} \text { EDTA }(\mathrm{pH} 8.0)\end{array}$

\subsubsection{Co-sedimentation Assays}

Recombinant fusion proteins consisting of glutathione S-transferase fused to syntaxin 1A (a.a 1-256), Munc13-1-176/178 (a.a 517-1735), Munc13-1-N1/N2 (a.a 3-317), Munc13-1-13'1 (a.a 1032-1345), or Munc13-1-3'13A (a.a 1399-1622) (Betz et al., 1997) were produced in E. coli using the pGEX-KG expression vector. Recombinant proteins were purified on glutathione-sepharose $4 \mathrm{~B}$, and immobilized on the resin for cosedimentation assays. Cell lysate from HEK293FT cells co-transfected with pEGFPMunc13-1 (full-length) and pMYC-Baiap3 (full-length) or crude whole brain extract from adult WT mice was solubilized at a concentration of $2 \mathrm{mg} / \mathrm{ml}$ in lysis buffer. After stirring on ice for $10 \mathrm{~min}$, insoluble material were removed by centrifugation at 15000 $\mathrm{rpm}$ for $30 \mathrm{~min}$ at $4{ }^{\circ} \mathrm{C}$. The equivalent of $3 \mathrm{mg}$ of total protein was incubated with 50 $\mu \mathrm{g}$ immobilized GST-fusion protein $\mathrm{ON}$ at $4{ }^{\circ} \mathrm{C}$ on a rotating wheel. Beads were washed 4 times with lysis buffer, resuspended in SDS-PAGE sample buffer, and analyzed by SDS-PAGE and immunoblotting using standard procedures. Immunoreactive proteins were visualized with ECL. The following primary antibodies were used for immunodetection: two monoclonal antibodies to MYC for Baiap3, to Syntaxin 1A/B, and a polyclonal antibody to Munc13-1. 


\subsubsection{Production of Anti-Baiap3 Antisera}

Polyclonal antibodies directed against Baiap3 were generated with a GST fusion protein as the antigen. Recombinant GST-Baiap3-MHDs fusion protein was generated by using the expression plasmid pGEX-Baiap3-MHDs, which expresses the residues 330-1150 of Baiap3 in the pGEX-KG vector. A polyclonal antibody that recognizes the N-terminus of Baiap3 (a.a 9-181) had previously been generated by Dr. Iris Augustin. Since the antibody produces a rather high background in immunofluorescence staining, we generate an antibody to a.a 330-1150 of Baiap3. We subcloned the regions spanning the MHDs to up to $\mathrm{C} 2 \mathrm{C}$ domain of Baiap3 into the pGEX-KG construct. The host immunization and bleeding of rabbits and guinea pigs was performed by Eurogentec. The antisera were derived from the final bleeding of the rabbits SA5990 and SA5991 and of the guinea pigs SAC106 and SAC107. Since the recombinant Baiap3 protein proved to be insoluble and furthermore stuck to the beads, the following purification procedures were used:

Subcloning of the Baiap3 MHDs

Primer 14 (\#11742): 5'-CCGGAATTCTAATGAACTTAGAGGTGGCCTCGG-3' Primer 15 (\#3417): 5'-TACGCGTCGACTCACCGGTTCTGCTCCAG-3'

$\begin{array}{ll}\text { Reaction Mixture } & \\ \text { 10X Buffer } & 10 \mu \mathrm{l} \\ \text { dNTPs } & 5 \mu \mathrm{l} \\ \text { Primer } 14 & 4 \mu \mathrm{l} \\ \text { Primer } 15 & 4 \mu \mathrm{l} \\ \text { Pfu Taq } & 1 \mu \mathrm{l} \\ \mathrm{dH}_{2} \mathrm{O} & 25 \mu \mathrm{l} \\ \text { Total } & 50 \mu \mathrm{l} \\ \text { Template DNA } & 1 \mu \mathrm{l}\end{array}$

PCR Program

$94^{\circ} \mathrm{C}$ for $3 \mathrm{~min}-1$ cycle

$94{ }^{\circ} \mathrm{C}$ for $30 \mathrm{sec}$
$55{ }^{\circ} \mathrm{C}$ for $30 \mathrm{sec}$

$72{ }^{\circ} \mathrm{C}$ for $1 \mathrm{~min}$

$72{ }^{\circ} \mathrm{C}$ for $10 \mathrm{~min}-1$ cycle

$10{ }^{\circ} \mathrm{C}$ for forever -1 cycle 
1. Inoculate one colony from LB-ampicillin plates with GST-Baiap3-MHDs into individual $5 \mathrm{ml}$ of $\mathrm{LB}$ broth containing ampicillin and grow $\mathrm{ON}$ at $37{ }^{\circ} \mathrm{C}$ with shaking incubator

2. Inoculate $1 \mathrm{~L}$ of $\mathrm{LB}$ with $5 \mathrm{ml}$ from step 1

3. Grow at $37^{\circ} \mathrm{C}$ with shaking for $4 \mathrm{hr}$

4. Induce expression of the protein by adding $0.3 \mathrm{mM} \mathrm{IPTG}$ and incubate for $4 \mathrm{hr}$ at $25{ }^{\circ} \mathrm{C}$ with shaking

5. Centrifuge the culture at $3500 \mathrm{~g}$ for $20 \mathrm{~min}$ at $4{ }^{\circ} \mathrm{C}$

6. Discard the supernatant and resuspend the pellet in $20 \mathrm{ml}$ PBS with protease inhibitors

7. Add Lysozyme and incubate for $10 \mathrm{~min}$ at RT

8. Sonicate the bacterial suspension on ice, three times in short $30 \mathrm{sec}$ bursts

9. Add $1 \%$ sodium cholate and incubate for $10 \mathrm{~min}$ at $4{ }^{\circ} \mathrm{C}$ with shaking

10. Centrifuge the lysate at $15000 \mathrm{~g}$ for $15 \mathrm{~min}$ at $4{ }^{\circ} \mathrm{C}$

11. Transfer the supernatant to a fresh tube

12. Add $1 \mathrm{ml}$ of a 50:50 slurry of Glutathione-Sepharose 4B beads in lysis buffer and incubate for $\mathrm{ON}$ at $4{ }^{\circ} \mathrm{C}$

13. Centrifuge at $750 \mathrm{~g}$ for $5 \mathrm{~min}$ at $4{ }^{\circ} \mathrm{C}$ to pellet the beads

14. Wash the beads four times in $5 \mathrm{ml}$ of cold wash buffer

15. Cleave between GST and Baiap3 fragment by thrombin digestion for $2 \mathrm{hr}$ at RT

16. Protein purification from the beads by Electro-HPLC (high performance liquid chromatography)

17. The denatured purified Baiap3 fragment was sent to Eurogentec for immunization 


\subsubsection{Antibodies, Chemicals, Kits and Reagents}

\begin{tabular}{|lll|}
\hline Antibodies & & \\
\hline Primary monoclonal & Source & Dilution \\
\hline Anti-ChromograninA & BD Biosciences & $1: 1000$ \\
\hline Anti-MYC & Abcam & $1: 3000$ \\
\hline Anti-NMDA R1 & Synaptic Systems & $1: 1000$ \\
\hline Anti-NSF & Abcam & $1: 2000$ \\
\hline Anti-SNAP 25 & Synaptic Systems & $1: 2000$ \\
\hline Anti-Synaptobrevin2 & Synaptic Systems & $1: 2000$ \\
\hline Anti-Synaptophysin & Synaptic Systems & $1: 2000$ \\
\hline Anti-Syntaxin1 & Synaptic Systems & $1: 2000$ \\
\hline Anti-Tubulin & Sigma & $1: 10.000$ \\
\hline & & \\
\hline Primary polyclonal & Source & Dilution \\
\hline Anti-BAI 1 & Abcam & $1: 1000$ \\
\hline Anti-Baiap3 & Shin et al. & $1: 500$ \\
\hline Anti-Munc13-1 (40.1) & Varoqueaux et al. & $1: 1000$ \\
\hline Anti-bMunc13-2 (44.1) & Varoqueaux et al. & $1: 1000$ \\
\hline Anti-ubMunc13-2 (48.1) & Varoqueaux et al. & $1: 1000$ \\
\hline Anti-Munc13-3 (52.1) & Varoqueaux et al. & $1: 1000$ \\
\hline Anti-Munc18-1 & Synaptic Systems & $1: 2000$ \\
\hline Anti-VMAT2 & Weihe et al. & Dilution \\
\hline & & $1: 10.000$ \\
\hline Secondary & Source & \\
\hline Anti-Mouse, & & \\
\hline HRP-conjugate & & \\
\hline Anti-Rabbit, & & \\
\hline HRP- conjugate & & \\
\hline
\end{tabular}

\begin{tabular}{|ll|}
\hline Chemicals & \\
\hline Product & Company \\
\hline Agarose & Gibco-BRL \\
\hline Ammoniumpersulfate & Sigma-Aldrich \\
\hline
\end{tabular}




\begin{tabular}{|c|c|}
\hline Ampicillin & Sigma-Aldrich \\
\hline Aprotinin & Roche \\
\hline Bacto-Yeast-Extract & DIFCO Laboratories \\
\hline Bacto-Trypton & DIFCO Laboratories \\
\hline Bacto-Pepton & DIFCO Laboratories \\
\hline Bacto-Agar & DIFCO Laboratories \\
\hline BAPTA & Signa-Aldrich \\
\hline BCA (Protein Assay) & Bio-Rad \\
\hline Bromophenol Blue & Sigma-Aldrich \\
\hline Coomassie Blue R250 & BIOMOL \\
\hline Chymotrypsin & Sigma-Aldrich \\
\hline$\left[\alpha^{32} \mathrm{P}\right] \mathrm{dCTP}$ & Amersham \\
\hline DEPC & Sigma-Aldrich \\
\hline DMSO & Sigma-Aldrich \\
\hline dNTP's & Pharmacia Biotech \\
\hline DTT & Sigma-Aldrich \\
\hline ECL-Reagents & Amersham-Buchler \\
\hline Films & Kodak \\
\hline Ethanol & JT Baker \\
\hline Ethidiumbromide & Sigma-Aldrich \\
\hline Ficoll 400 & Pharmacia Biotech \\
\hline Fura-4F & Invitrogen \\
\hline Glutathion Sepharose 4B & Sigma-Aldrich \\
\hline Glutathion-Agarose Matrix & Sigma-Aldrich \\
\hline Glycin & Bio-Rad Laboratories \\
\hline IPTG & BioMol Feinchemikalien \\
\hline Isopropanol & Merck \\
\hline Kanamycin & Sigma-Aldrich \\
\hline Klenow-Fragment & Roche \\
\hline Leupeptin & Roche \\
\hline Lysozym & Sigma-Aldrich \\
\hline Ni-NTA-Agarose-Matrix & Qiagen \\
\hline NP-EGTA & Synaptic Systems \\
\hline $\mathrm{Mg}^{2+}$-Fura-2 & Invitrogen \\
\hline Paraformaldehyde & BIOMOL \\
\hline PBS & Sigma-Aldrich \\
\hline Pfu-Polymerase & Stratagene \\
\hline Phenol-Chloroform & ROTH \\
\hline
\end{tabular}




\begin{tabular}{|ll|}
\hline PMSF & Roche \\
\hline Ponceau S & Sigma-Aldrich \\
\hline Protein Assay & Bio-Rad Laboratories \\
\hline Proteinase K & Boehringer Mannheim \\
\hline Rapid-hyb. Buffer & Amersham pharmacia \\
\hline Rat Quick Clone cDNA, MouseBrain & Clontech \\
\hline SDS & Roche \\
\hline Standard Molecular weight marker & Prestained Standards, Bio-Rad \\
\hline T4-DNA-Ligase & Roche \\
\hline T4-DNA-Polymerase & Roche \\
\hline Taq-Polymerase & ABI \\
\hline Temed & Sigma-Aldrich \\
\hline 2,2,2-Tribromethanol & Sigma-Aldrich \\
\hline Tris Base & Sigma-Aldrich \\
\hline Triton X-100 & Roche \\
\hline Dry Milk & Nestle \\
\hline Tween 20 & Sigma-Aldrich \\
\hline X-Gal & BIOMOL \\
\hline
\end{tabular}

\begin{tabular}{|ll|}
\hline Kits & \\
\hline Product & Company \\
\hline Centricon 10 & Amicon GmbH \\
\hline ECL-film & Amersham \\
\hline Electroporation Cuvettes & Bio-Rad Laboratories \\
\hline Hybond-N ${ }^{+}$-Membrane & Amersham \\
\hline Plasmid-Purification Kit & Qiagen \\
\hline Prime-It II-Random Primer Labelling Kit & Stratagene \\
\hline Protran (nitrocellulose transfer membrane) & Whatman International \\
\hline Shrimp Alkaline Phosphatase & Roche \\
\hline SP6 in vitro transcription Kit & Roche \\
\hline Topo T/A und Topo XL Cloning Kit & Invitrogen \\
\hline Qiafilter Plasmid Kit & Qiagen \\
\hline Qiaquick Gel-Extraction Kit & Qiagen \\
\hline Qiaquick PCR-Purification Kit & Qiagen \\
\hline Whatman 3MM paper & Whatman International \\
\hline
\end{tabular}




\begin{tabular}{|ll|}
\hline Reagents & \\
\hline Product & Company \\
\hline$\beta$-Mercaptoethanol "cell culture tested" & Sigma-Aldrich \\
\hline DMEM & Gibco-BRL \\
\hline Knockout DMEM & Gibco-BRL \\
\hline Fetal Calf Serum & Hyclone \\
\hline Fetal Bovine Serum & Hyclone \\
\hline G418 & Invitrogen \\
\hline L-Cysteine & Gibco-BRL \\
\hline L-Glutamine $(100 \mathrm{x})$ & Gibco-BRL \\
\hline Lipofectamin 200 & Invitrogen \\
\hline NEAA (100 $\mathrm{x})$ & Gibco-BRL \\
\hline Neurobasal Medium & Gibco-BRL \\
\hline Papain & Worthington \\
\hline Penicillin/Streptomycin & Gibco-BRL \\
\hline Opti-MEM & Gibco-BRL \\
\hline Trypsin-EDTA $(0.05 \mathrm{x})$ & Gibco-BRL \\
\hline Trypsin-EDTA $(0.25 \%)$ & Gibco-BRL \\
\hline
\end{tabular}

\subsection{Electrophysiological Analysis}

\subsubsection{Whole Cell Capacitance Measurements}

Conventional whole-cell recordings were performed at $30{ }^{\circ} \mathrm{C}$ with $3-5 \mathrm{M} \Omega$ pipettes (Kimax-51; Kimble/Kontes, Vineland, NJ) (Voets et al., 2000). An EPC-9 patch-clamp amplifier was used together with the Pulse software package (HEKA Electronics, Lambrecht, Germany). Capacitance measurements were performed by using the LindauNeher technique implemented as the "sine $+\mathrm{dc}$ " mode of the software lock-in extension 
of pulse, which allowed long-duration capacitance measurements in a single sweep. A $1000 \mathrm{~Hz}, 70 \mathrm{mV}$ peak-to-peak sinusoid voltage stimulus was superimposed onto a DC holding potential of $-70 \mathrm{mV}$. Currents were filtered at $3 \mathrm{kHz}$ and sampled at $12 \mathrm{kHz}$.

The capacitance traces were exported to Axograph (Axograph Scientific, Sydney, Australia) for analysis. Displayed traces are averages for each condition, with the number of cells given in the figure legends. To control for variation between preparations, we always compared WT or heterozygous and $\mathrm{KO}$ chromaffin cells obtained from the same preparation. Kinetic data were obtained by fitting individual capacitance recordings with a sum of three exponential functions.

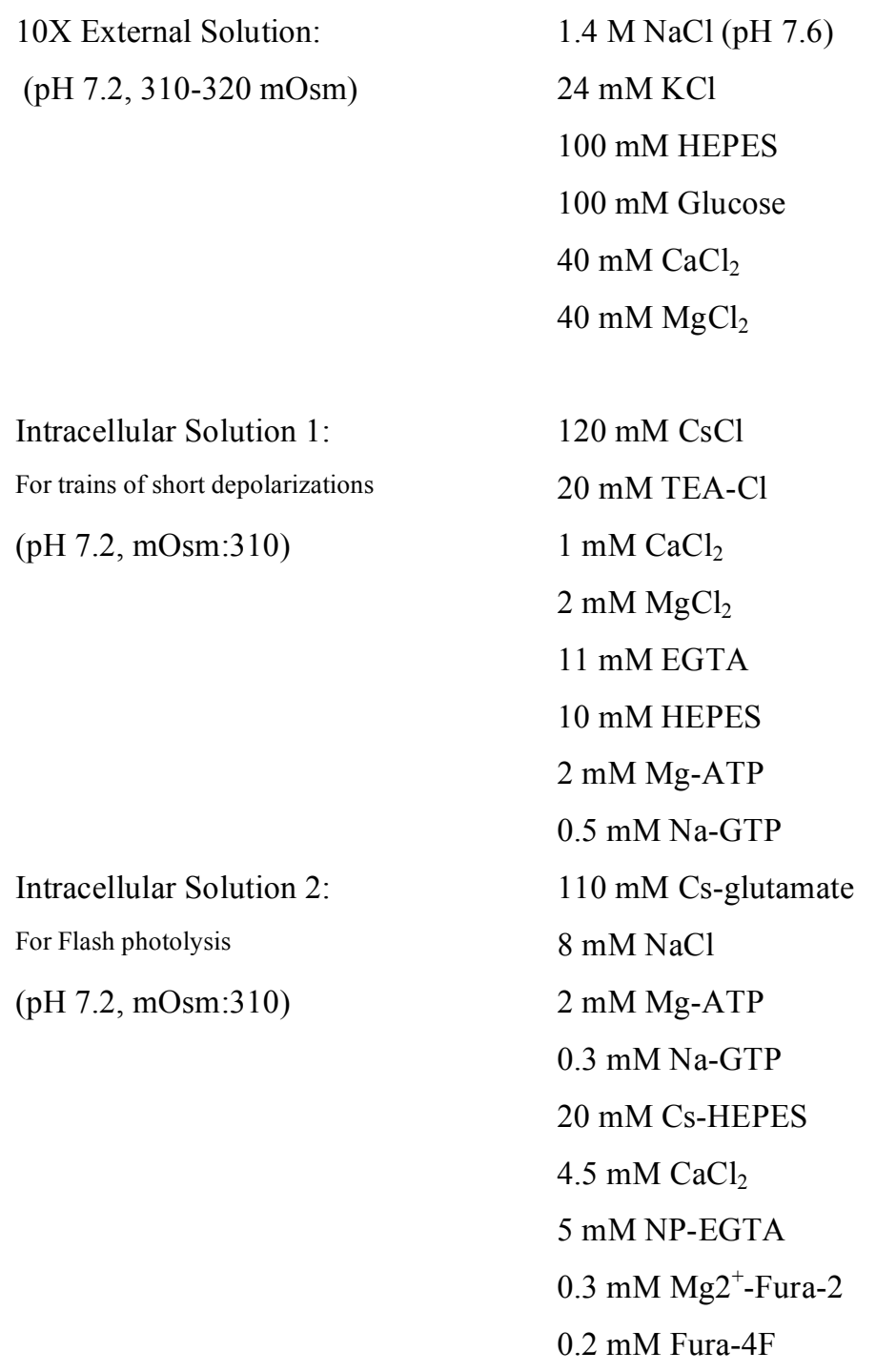




\subsubsection{Flash Photolysis of Caged $\mathrm{Ca}^{2+}$ and Measurements of $\left[\mathrm{Ca}^{2+}\right]_{\mathrm{i}}$}

Flashes of UV light were generated by a flash lamp (Rapp Optoelektronik, Hamburg, Germany), and fluorescence excitation light was generated by a monochromator (TILL Photonics, Planegg, Germany) as described previously (Gillis et al., 1996; Xu et al., 1998); these were coupled into the epifluorescence port of an inverted Axiovert 100 microscope with a 40X Fluorobjective (Zeiss, Oberkochen, Germany). $\mathrm{Mg}^{2+}$-Fura-2 was excited at $380 / 340 \mathrm{~nm}$, and the illumination area was reduced to cover only the diameter of the cell. Emitted light was attenuated with a neutral density filter, detected with an avalanche photodiode (TILL Photonics, Planegg, Germany), filtered at $3 \mathrm{kHz}$ and sampled at $12 \mathrm{kHz}$ by Pulse software (Ashery et al., 2000). The basal $\left[\mathrm{Ca}^{2+}\right]_{\mathrm{i}}$ was measured to be $220 \mathrm{nM}$ by fura- 2 in vivo using calibration solution $1\left(\mathrm{R}_{\mathrm{min}}\right)$, solution 2 $\left(\mathrm{R}_{\max }\right)$, solution $3\left(\mathrm{~K}_{\mathrm{eff}}\right)$, and solution 4 ( $\alpha$-coefficient). The flash photolysis efficiency was also measured as described (Xu et al., 1998). The photolysis efficiency of a $350 \mathrm{~V}$ discharge flash for NP-EGTA was determined to be $30 \%$. Fluorescence excitation light was used to measure $\left[\mathrm{Ca}^{2+}\right]_{\mathrm{i}}$ and simultaneously photorelease $\mathrm{Ca}^{2+}$ after the flashes in order to keep $\left[\mathrm{Ca}^{2+}\right]_{\mathrm{i}}$ approximately constant. $\left[\mathrm{Ca}^{2+}\right]_{\mathrm{i}}$ was calculated from the fluorescence ratio (R) according to Grynkiewiez et al (1985) and the flash photolysis efficiency was calculated as according to published protocols (Xu et al., 1998). Fluorescent excitation light was used not only to measure but also to adjust before and after flash. The basal $\mathrm{Ca}^{2+}$ concentration before the flash was $500-900 \mathrm{nM}$.

Each cell was patched under conditions as follows;

1. Access resistance is low, preferably $<7 \mathrm{MOhm}$

2. Leak current is low, preferably $<20 \mathrm{pA}$ 
3. Fluorescence ratio is stable before the flash

4. Loading with dye saturates, indicating the cell is not swelling excessively

\begin{tabular}{|c|c|}
\hline \multirow[t]{2}{*}{ 2X Pipette Solution: } & $250 \mathrm{mM}$ Cs-glutamate \\
\hline & 80 mM Cs-HEPES (pH 7.2) \\
\hline \multirow[t]{3}{*}{ 10X Nucleotide: } & $20 \mathrm{mM} \mathrm{Mg}$-ATP \\
\hline & $3 \mathrm{mM} \mathrm{Na-GTP}$ \\
\hline & 10 mM HEPES (pH 7.2) \\
\hline \multirow[t]{4}{*}{ Solution 1: } & 20 mM BAPTA \\
\hline & 1X Pipette solution \\
\hline & 1X Nucleotide \\
\hline & $0.5 \mathrm{mM}$ Fura-2 \\
\hline \multirow[t]{4}{*}{ Solution 2: } & $10 \mathrm{mM} \mathrm{CaCl}_{2}$ \\
\hline & 1X Pipette solution \\
\hline & 1X Nucleotide \\
\hline & $0.5 \mathrm{mM}$ Fura-2 \\
\hline \multirow[t]{5}{*}{ Solution 3: } & 20 mM BAPTA \\
\hline & $13.33 \mathrm{mM} \mathrm{CaCl}_{2}$ \\
\hline & 1X Pipette solution \\
\hline & 1X Nucleotide \\
\hline & $0.5 \mathrm{mM}$ Fura-2 \\
\hline \multirow[t]{3}{*}{ Solution 4: } & 1X Pipette solution \\
\hline & 1X Nucleotide \\
\hline & 0.2 mM Fura-2 \\
\hline
\end{tabular}

\subsubsection{Data Analysis and Statistics}

Data were analyzed offline using AxoGraph 4.9 or AxoGraph X 1.0 (AxoGraph Scientific, Sydney, Australia) and Kaleidagraph 4.0 (Synergy Software, PA, USA). Statistical significance was tested using Student's $t$-test. 


\section{Results}

\subsection{Analysis of the Role of the Munc13 Protein Family in LDCV Exocytosis}

\subsubsection{Reduced Exocytosis in Chromaffin Cells from Munc13-1 KO Mice}

Munc13-1 is expressed in bovine chromaffin cells, which are used as a model for LDCV secretion (Ashery et al., 2000) and is also present in mouse adrenal gland (Figure 16A). The role of Munc13-1 in SV exocytosis has been investigated in individual hippocampal primary neurons cultured on astrocyte feeder islands (microisland culture) (Augustin et al., 1999b). Munc13-1 deficient neurons showed a striking deficit in evoked and spontaneous neurotransmitter release. In present study, we investigated whether the absence of Munc13-1 affects exocytosis of LDCVs in mouse adrenal chromaffin cells (Figure 6F). We performed whole-cell patch clamp recordings combined with flash photolysis of caged $\mathrm{Ca}^{2+}$ on chromaffin cells cultured from P0 adrenal glands. Flash photolysis of caged $\mathrm{Ca}^{2+}$ typically causes a biphasic increase in membrane capacitance. Upon photolysis of caged $\mathrm{Ca}^{2+}$, release was undetectable at $\mathrm{Ca}^{2+}$ concentration of $<1 \mu \mathrm{M}$, became measurable at $1-2 \mu \mathrm{M} \mathrm{Ca}^{2+}$, and resembled the release observed during a normal action potential at $>5 \mu \mathrm{M} \mathrm{Ca}^{2+}$, and saturated at $>20 \mu \mathrm{M}$ $\mathrm{Ca}^{2+}$ (Bollmann et al., 2000).

We found that, in chromaffin cell from Munc13-1 KO mice, both the exocytotic burst and the sustained component were significantly reduced (Burst: by $\sim 40 \%$, and Sustained: by $\sim 50 \%$; Figure 6A-C; Table 1). 


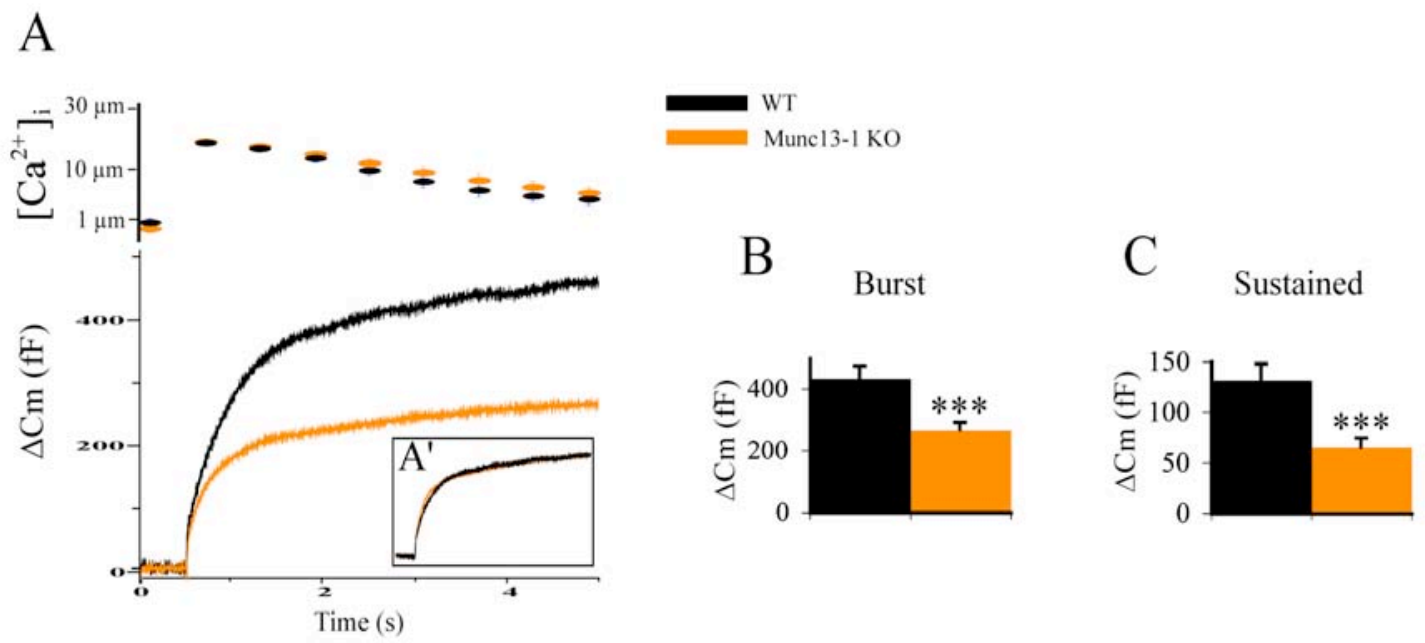

D Fast Burst Component

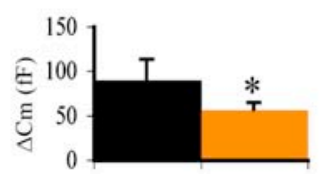

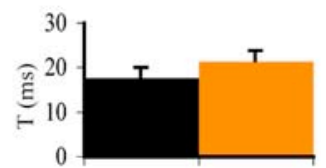

E

Slow Burst Component
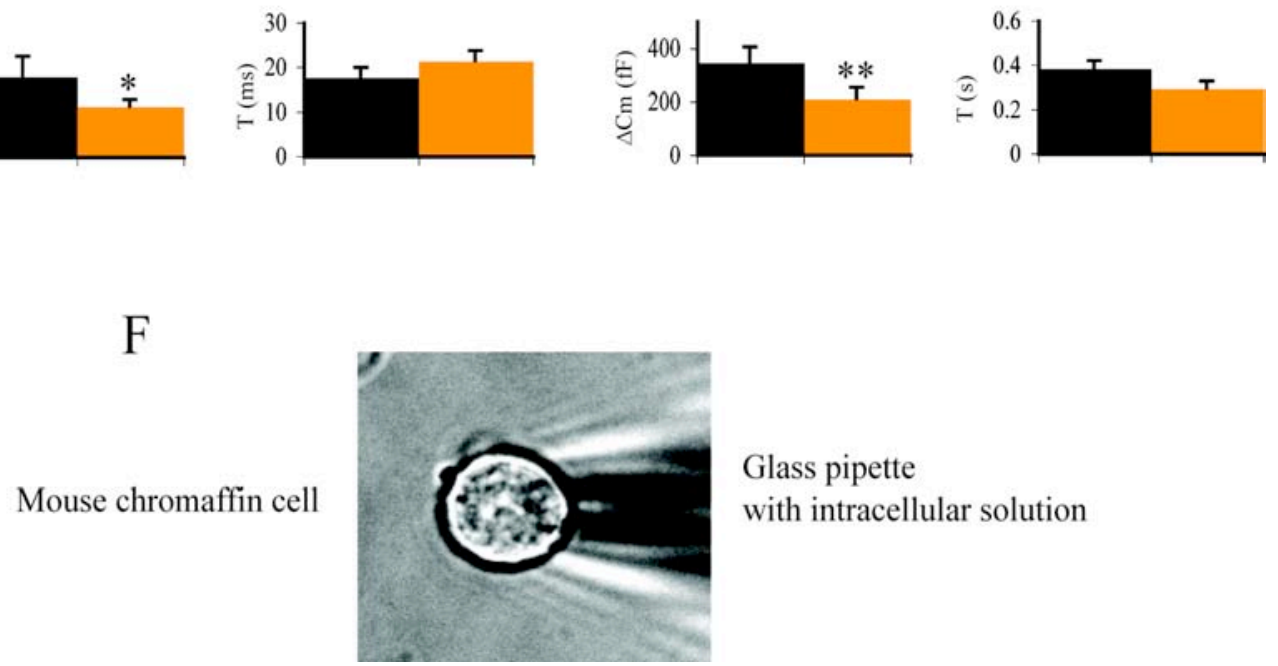

Figure 6. Reduced exocytosis in chromaffin cells from Munc13-1 deficient mice.

(A) Average $\Delta \mathrm{Cm}$ in response to flash photolysis of NP-EGTA in chromaffin cells cultured at P0 from WT (28 cells from 5 mice, black line) and Munc13-1 KO mice (32 cells from 5 mice, orange line). The intracellular $\mathrm{Ca}^{2+}$ concentration following the flash is shown in the upper trace. $\left(\mathrm{A}^{\prime}\right)$ The Munc13-1 KO trace was normalized to the WT amplitude at $4 \mathrm{~s}$ after the flash. (B-C) Comparison of the exocytotic burst $(P=0.0007)$ and sustained release $(P=0.0005)$ in WT control and Munc13-1 KO cells. The exocytotic burst and sustained release were determined as the $\Delta \mathrm{Cm} 1 \mathrm{~s}$ and $2 \mathrm{~s}$ to $5 \mathrm{~s}$ after the flash, respectively. (DE) Kinetic analysis of the capacitance traces revealed that the two burst components, fast $(P=0.032)$ and slow $(P=0.035)$, are both reduced in amplitude, without any change in the time constant. Error bars indicate standard error of the mean. (F) Representative mouse chromaffin cell with attached glass pipette. *, $P<0.05$; **, $P<0.01$; ***, $P<0.001$. 
In order to investigate the release kinetics of exocytosis, we fitted individual capacitance traces with a sum of exponentials within the first second after the flash. The amplitudes of the capacitance traces represent the vesicle pool sizes, whereas the time constants identify their fusion kinetics. The first phase, the exocytotic burst, can be further subdivided into a fast burst (fusion with a time constant of $\sim 20 \mathrm{~ms}$ at $20 \mu \mathrm{M}$ $\mathrm{Ca}^{2+}$ ) and a slow burst (fusion with a time constant of $>200 \mathrm{~ms}$ at $20 \mu \mathrm{M} \mathrm{Ca}^{2+}$ ) components (Sørensen et al., 2003). These phases represent fusion of two distinct pools of docked and primed vesicles, the RRP and the SRP. The slow component or SRP represents a precursor state to the fast component or RRP and the sustained phase of secretion, which persists for several seconds, is thought to represent refilling of the primed vesicle pools (Voets et al., 1999).

In chromaffin cell from Munc13-1 deficient mice, we found that both the fast and the slow burst components were significantly smaller than in WT chromaffin cells, but that vesicle fusion kinetics were not affected (Figure 6D-E, Table 1). To examine whether the reduction in Munc13-1 KO exocytosis obscures a difference in the kinetics of the sustained phase, we normalized the traces to the sustained phase of release at $4 \mathrm{~s}$ (Figure $\left.6 \mathrm{~A}^{\prime}\right)$. However, no change in the kinetics of the sustained phase or the relative amplitudes of burst and sustained component were detected, indicating that the Munc13-1 deficiency impairs the docking/priming reactions necessary for the release of all vesicles, rather than affecting the burst phase or sustained phase selectively. Postflash $\left[\mathrm{Ca}^{2+}\right]_{\mathrm{i}}$ was closely matched between KO and WT cells (Figure 6A, top), which shows that the release deficit in Munc13-1 KO chromaffin cells is not due to altered $\mathrm{Ca}^{2+}$ levels. These findings demonstrate that loss of Munc13-1 leads to a reduction of both the pool of fusion-competent LDCVs and to a reduction of 
recruitment of new LDCVs into this pool, without affecting the kinetics of the fusion step.

\subsubsection{Reduced Exocytosis in Chromaffin Cells from Munc13-2 KO Mice}

Munc13-2 is expressed in bovine chromaffin cells (Zikich et al., 2008) and also in mouse adrenal gland (Figure 17A). To test whether Munc13-2 is required for exocytosis of LDCVs, we stimulated chromaffin cells obtained from P0 WT and Munc13-2 KO littermates using flash photolysis of caged $\mathrm{Ca}^{2+}$. We found that in chromaffin cells from Munc13-2 deficient mice, both the exocytotic burst and the sustained component were reduced (Burst: by $\sim 30 \%$, and Sustained: by $\sim 40 \%$; Figure 7A-C; Table 1), however, the reduction was statistically not significant (Figure 7).

When we investigated the release kinetics of exocytosis by fitting individual capacitance traces within the first $1 \mathrm{~s}$ after the flash with a sum of exponentials, we found that in chromaffin cell from Munc13-2 KO mice, both the fast and slow burst were reduced, but the reduction was statistically not significant (Figure 7D-E, Table 1). Like the loss of Munc13-1, loss of Munc13-2 also had no effect on the vesicular release kinetics during the exocytotic burst (Figure 7D-E, Table 1), nor did normalization of the traces to the sustained component reveal a selective alteration of the kinetics of the sustained component (Figure $7 \mathrm{~A}^{\prime}$ ). Postflash $\left[\mathrm{Ca}^{2+}\right]_{\mathrm{i}}$ was closely matched between $\mathrm{KO}$ and WT cells (Figure 7A, top). In cultured hippocampal neurons obtained from Munc13-2 KO mice, SV exocytosis was not affected, suggesting a compensatory effect of Munc13-1 in Munc13-2 KO neurons (Varoqueaux et al., 2002). 
A
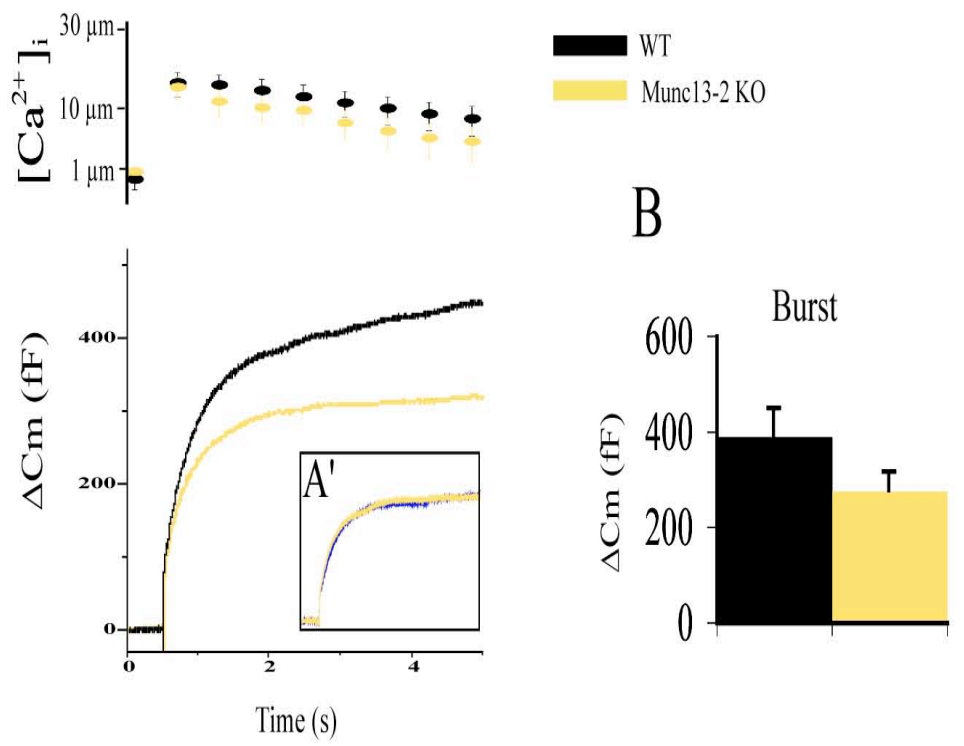

Sustained

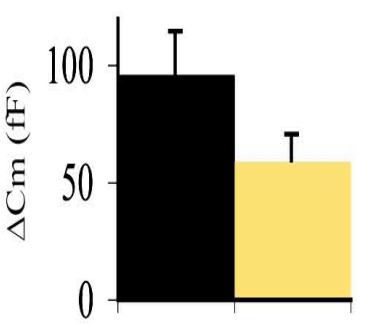

D

Fast Burst Component

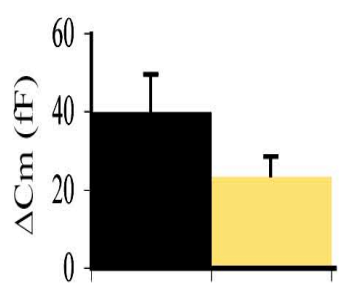

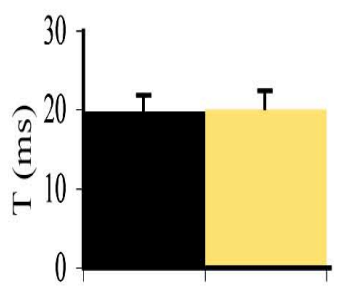

Slow Burst Component

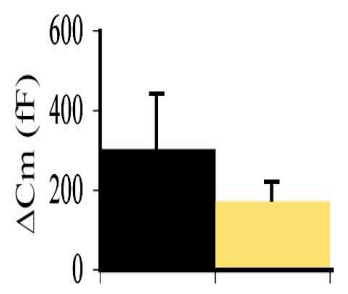

Figure 7. Reduced exocytosis in chromaffin cells from Munc13-2 deficient mice.

(A) Average $\Delta \mathrm{Cm}$ in response to flash photolysis of NP-EGTA in P0 WT control (21 cells from 4 mice, black line) and Munc13-2 KO (22 cells from 4 mice, vanilla line). The intracellular $\mathrm{Ca}^{2+}$ concentration following the flash is shown in the upper trace. (A') The Munc13-2 KO trace was normalized to the WT amplitude at $4 \mathrm{~s}$ after the flash. (B-C) Comparison of the exocytotic burst $(P=0.096)$ and sustained release $(P=0.080)$ in WT control and Munc13-2 KO cells. The exocytotic burst and sustained release were determined as the $\Delta \mathrm{Cm} 1 \mathrm{~s}$ and $2 \mathrm{~s}$ to $5 \mathrm{~s}$ after the flash, respectively. (D-E) Kinetic analysis of the capacitance traces revealed that the two burst components, fast $(P=0.13)$ and slow $(P=0.95)$, are both reduced in amplitude, without any change in the time constant. Error bars indicate standard error of the mean. *, $P<0.05$; **, $P<0.01$; **, $P<0.001$. 
Although the release deficit in Munc13-2 KO LDCV exocytosis was statistically not significant, our data indicate that in the regulation of LDCV exocytosis in mouse chromaffin cells, Munc13-1 may not be able to fully compensate for the loss of Munc13-2.

\subsubsection{Reduced Exocytosis in Chromaffin Cells from Munc13-1/2DKO Mice}

In this study, we found that both the exocytotic burst and the sustained phase component were reduced in chromaffin cells deficient for either Munc13-1 or Munc132 (Figure 6A-E, 7A-E). Next, we investigated LDCV secretion in chromaffin cells lacking both Munc13-1 and -2. Munc13-1/2 DKO mice are completely paralyzed, die immediately after birth and neurotransmitter secretion from both GABAergic and glutamatergic hippocampal neurons is completely abolished in Munc13-1/2 DKO mice (Varoqueaux et al., 2002). Thus we expected that LDCV exocytosis (both the exocytotic burst and the sustained component) might be abolished in Munc13-1/2 deficient chromaffin cells. We analyzed adrenal chromaffin cells from E18 (Embryonic day 18) embryos that were obtained by caesarean section of pregnant females from Munc13-1 heterozygous and Munc13-2 homozygous KO background matings. Munc13-2 KO chromaffin cells were used as controls and compared with Munc13-1/2 DKO chromaffin cells. Interestingly, we found that the adrenal glands from Munc13-1/2 DKO mice were about 50\% smaller than those of Munc13-2 KOs, which were indistinguishable from WT adrenal glands (data not shown). 


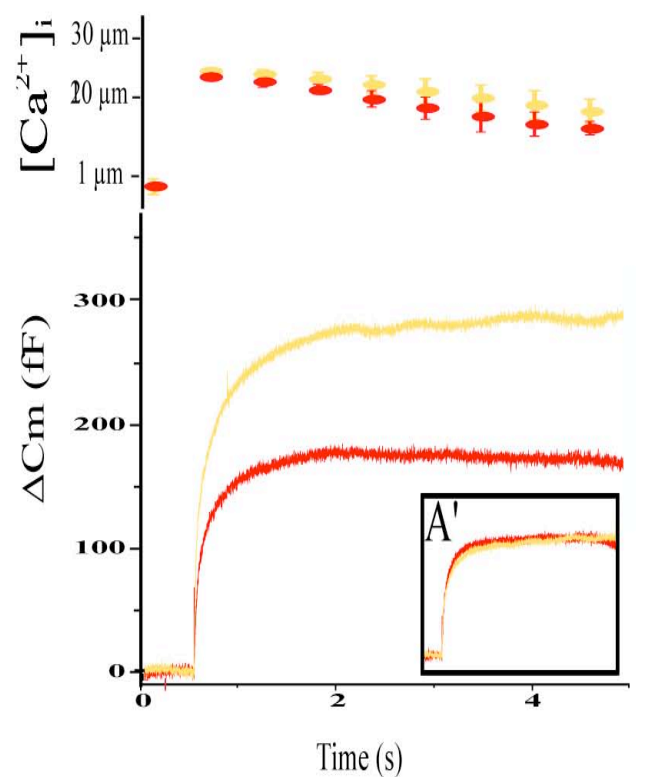

D

Fast Burst Component
Munc13-2 K0

Munc13-1/2 DKO

B

Burst
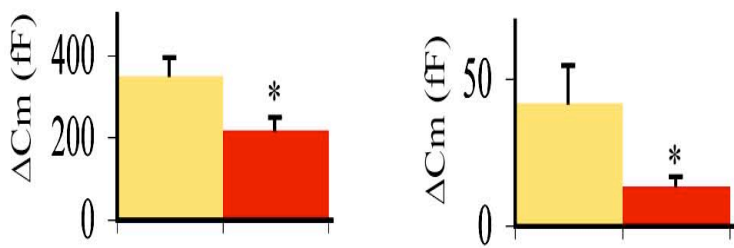

E

Slow Burst Component
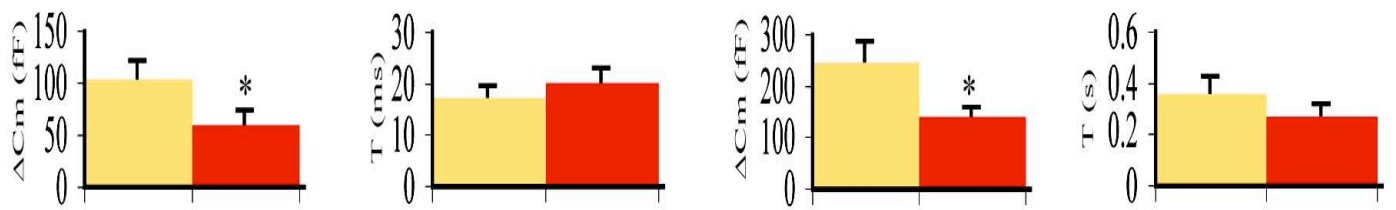

Figure 8. Reduced exocytosis in chromaffin cells from Munc13-1/2 DKO mice.

(A) Exocytosis in mouse chromaffin cells from Munc13-2 KO and Munc13-1/2 DKO mice after flash photolysis of caged $\mathrm{Ca}^{2+}$. Average $\Delta \mathrm{Cm}$ in response to flash photolysis of NP-EGTA in Munc13-2 KO (12 cells from 3 mice) and Munc13-1/2 DKO (14 cells from 3 mice). The intracellular $\mathrm{Ca}^{2+}$ concentration following the flash is shown in the upper trace. ( $\left.\mathrm{A}^{\prime}\right)$ The Munc13-1/2 DKO trace was normalized to the Munc13-2 KO amplitude at $4 \mathrm{~s}$ after the flash. (B-C) Comparison of the exocytotic burst $(P=0.0014)$ and sustained release $(P=0.024)$ in control and Munc13-1/2 DKO cells. The exocytotic burst and sustained release were determined as the $\Delta \mathrm{Cm} 1 \mathrm{~s}$ and $2 \mathrm{~s}$ to $5 \mathrm{~s}$ after the flash, respectively. (D-E) Kinetic analysis of the capacitance traces revealed that the two burst components, fast $(P=0.040)$ and slow $(P=0.011)$, are both changed. Error bars indicate standard error of the mean. * $P<0.05$; **, $P<0.01$; ***, $P<0.001$. 
To test whether secretion is completely abolished in Munc13-1/2 DKO cells, we stimulated the chromaffin cells obtained from Munc13-2 KO and Munc13-1/2 DKO littermates using flash photolysis of caged $\mathrm{Ca}^{2+}$. We found that in chromaffin cell from the Munc13-1/2 DKO mice, both the exocytotic burst (by $\sim 40 \%$, Figure $8 \mathrm{~B}$, Table 1) and the sustained component (by $\sim 70 \%$, Figure $8 \mathrm{C}$, Table 1 ) were reduced significantly compared to Munc13-2 KO cells (Figure 8A).

However, in contrast to the complete shutdown of SV exocytosis from Munc13-1/2 DKO hippocampal neurons (Varoqueaux et al., 2002), exocytosis from chromaffin cells, although drastically reduced, was not abolished entirely in the absence of both Munc13-1 and -2 .

In order to investigate the release kinetics of exocytosis we fitted individual capacitance traces within the first $1 \mathrm{~s}$ after the flash with a sum of exponentials. We found that compared to chromaffin cells from Munc13-2 KO littermates, cells from Munc13-1/2 DKO mice showed a reduction of $40 \%$ in the fast and of $75 \%$ in the slow burst amplitude (Figure 8D-E, Table 1). Taking into account that, compared to WT, Munc13-2 KO cells already have a 30\%-40\% reduction of exocytosis, both the exocytotic burst and the sustained component were reduced more drastically in the Munc13-1/2 DKOs than in either single KO (Figure 20). Furthermore, like the loss of Munc13-1 or Munc13-2 alone, the absence of both isoforms had no effect on the vesicular release kinetics during the exocytotic burst (Figure 8D-E, Table 1), nor did normalization of the traces to the sustained component reveal a selective alteration of

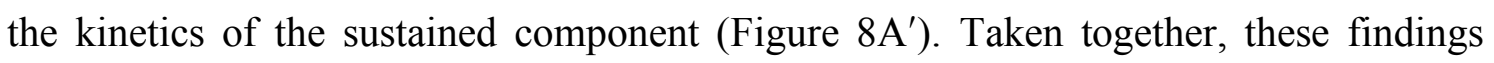
indicate that the presence of Munc13-1 suffices for the establishment of an almost WTsized pool of LDCVs released in the initial burst, but recruitment of new vesicles into 
the releasable pool during ongoing release is severely impaired in the absence of both isoforms. As in the previous experiments, no effect on $\left[\mathrm{Ca}^{2+}\right]_{\mathrm{i}}$ was detected in the absence of Munc13-1 and Munc13-2 (Figure 8A, top). Thus, both Munc13-1 and -2 are positive regulators in LDCV exocytosis in mouse chromaffin cells.

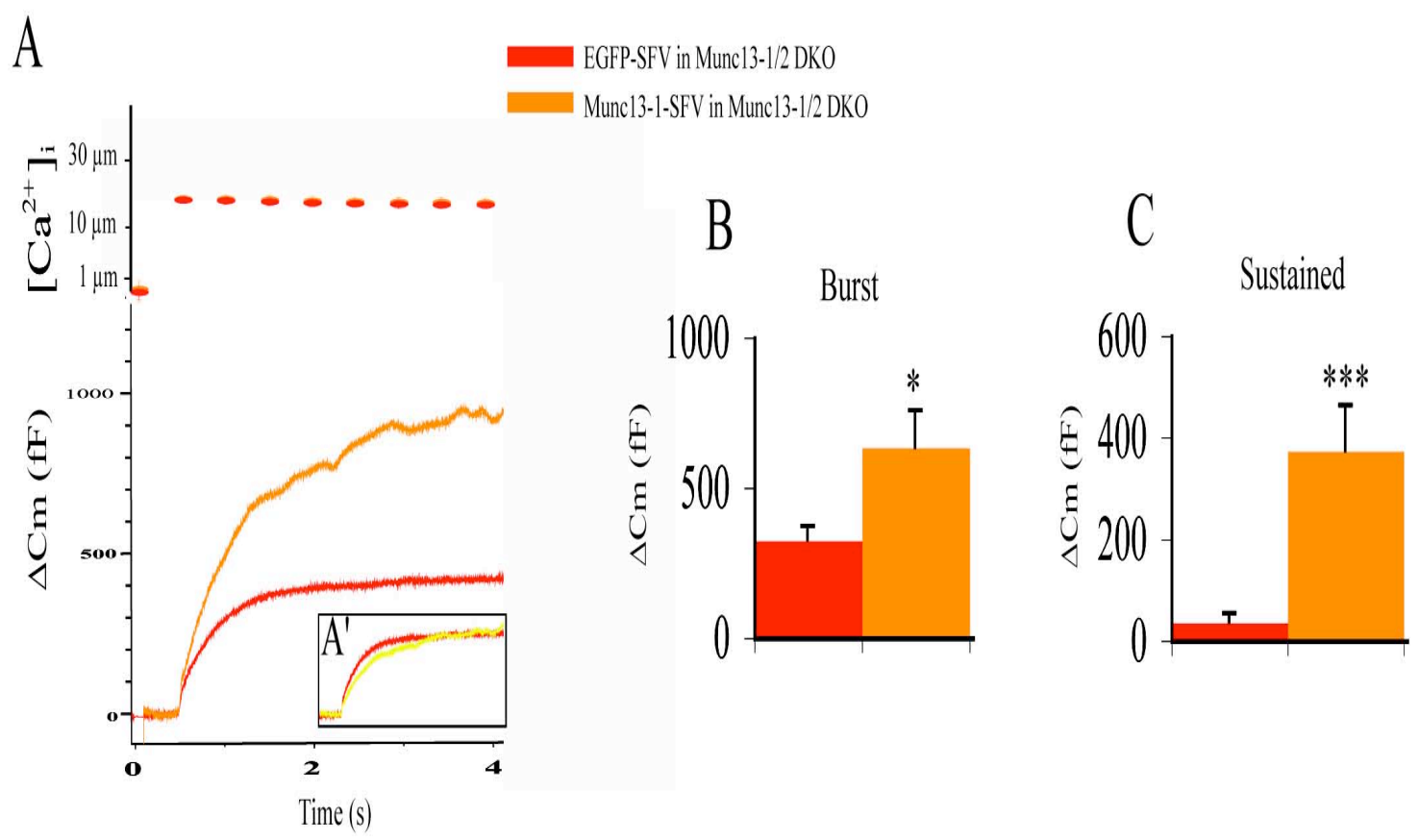

\section{Figure 9. Rescue of exocytosis in Munc13-1/2DKO chromaffin cells by overexpression of Munc13-1}

(A) Average $\triangle \mathrm{Cm}$ in response to flash photolysis of NP-EGTA in E18 Munc13-1/2 DKO cells overexpressing either EGFP ( 9 cells from 3 mice) or Munc13-1 ( 7 cells from 3 mice). The intracellular $\mathrm{Ca}^{2+}$ concentration following the flash is shown in the upper trace. (A') The Munc13-1-SFV trace was normalized to the EGFP-SFV amplitude at $4 \mathrm{~s}$ after the flash. (B-C) Comparison of the exocytotic burst $(P=0.019)$ and sustained release $(P=0.0009)$ in cells overexpressing EGFP and cells overexpressing Munc13-1. The exocytotic burst and sustained release were determined as the $\Delta \mathrm{Cm} 1 \mathrm{~s}$ and $2 \mathrm{~s}$ to $5 \mathrm{~s}$ after the flash, respectively. Error bars indicate standard error of the mean. *, $P<0.05 ; * *, P<0.01$; ***, $P$ $<0.001$. 
To confirm these results, we tested whether Munc13-1-SFV overexpression in Munc13-1/2 DKO chromaffin cells would rescue secretion. Using the SFV expression system, we infected mouse chromaffin cells obtained from Munc13-1/2 DKO mice with the RNA coding for Munc13-1 tagged with EGFP (Enhanced Green Fluorescent Protein) (Ashery et al., 1999). The average capacitance after flash photolysis of caged $\mathrm{Ca}^{2+}$ was larger in Munc13-1 overexpressing cells than in EGFP overexpressing cells (Figure 9A). Both the exocytotic burst (Figure 9B, 633.72 $\pm 121.3 \mathrm{fF}, P=0.019$ ) and the sustained component (Figure 9C, $372.57 \pm 88.56 \mathrm{fF}, P=0.0009$ ) were increased significantly. Normalization of the Munc13-1-SFV trace to the trace of EGFP-SFV control cells revealed no significant changes in the kinetics of the sustained component (Figure 9A'). Thus, in agreement with previous studies that showed that overexpression of Munc13-1 in WT chromaffin cells boosted LDCV release (Ashery et al., 2000), overexpression of Munc13-1 in Munc13-1/2 DKO chromaffin cells leads to both a larger amount of fusion-competent vesicles and a more rapid vesicle supply.

\subsubsection{Exocytosis in Chromaffin Cells from Munc13-3 KO and Munc13-}

\section{1/2/3 TKO Mice}

In addition to Munc13-1 and -2, a third Munc13 isoform, Munc13-3, is also expressed in bovine chromaffin cells (Ashery et al., 2000) and mouse adrenal gland (Figure 17A). To test whether Munc13-3 also contributes to the regulation of LDCV exocytosis, we stimulated chromaffin cells obtained from P0 WT and Munc13-3 KO littermate mice using flash photolysis of caged $\mathrm{Ca}^{2+}$. 
A

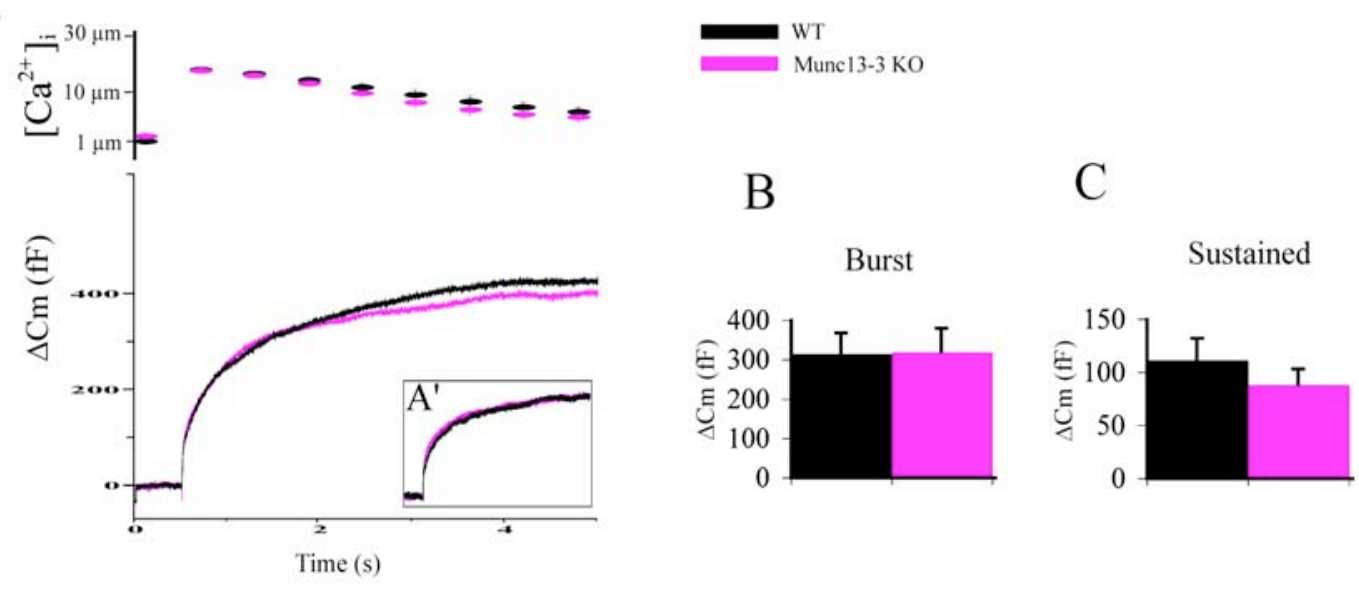

D

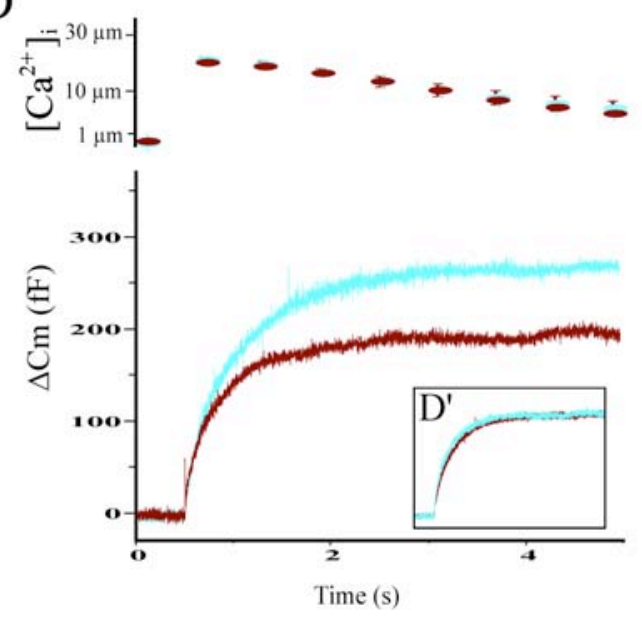

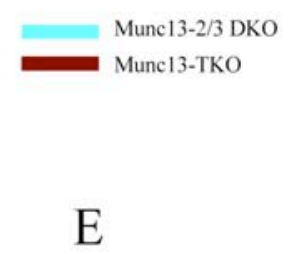

Burst

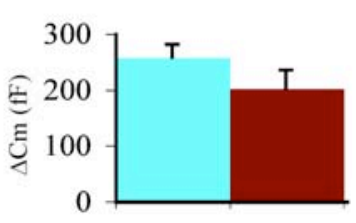

$\mathrm{F}$

Sustained

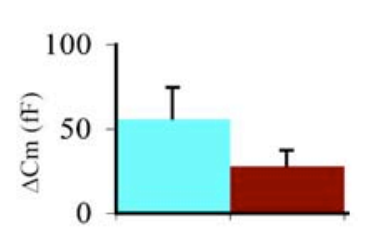

Figure 10. Exocytosis in chromaffin cells from Munc13-3KO and Munc13-1/2/3 Triple knockout (TKO) mice.

(A) Average $\Delta \mathrm{Cm}$ in response to flash photolysis of NP-EGTA in chromaffin cells cultured at P0 from WT ( 15 cells from 3 mice, black line) and Munc13-3 KO mice (12 cells from 3 mice, magenta line). The intracellular $\mathrm{Ca}^{2+}$ concentration following the flash is shown in the upper trace. ( $\mathrm{A}^{\prime}$ ) The Munc13-3 KO trace was normalized to the WT amplitude at $4 \mathrm{~s}$ after the flash. (B-C) Comparison of the exocytotic burst and sustained release in WT control and Munc13-3 KO cells. The exocytotic burst and sustained release were determined as the $\Delta \mathrm{Cm} 1 \mathrm{~s}$ and $2 \mathrm{~s}$ to $5 \mathrm{~s}$ after the flash, respectively. (D) Average $\Delta \mathrm{Cm}$ in response to flash photolysis of NP-EGTA in chromaffin cells cultured at E18 from Munc13-2/3 DKO (17 cells from 3 mice, blue line) and Munc13-1/2/3 TKO mice (13 cells from 3 mice, purple-red line). The intracellular $\mathrm{Ca}^{2+}$ concentration following the flash is shown in the upper trace. $\left(\mathrm{D}^{\prime}\right)$ The Munc13-1/2/3 TKO trace was normalized to Munc13-2/3 DKO amplitude at $4 \mathrm{~s}$ after the flash. (E-F) Comparison of the exocytotic burst and sustained release in Munc13-2/3 DKO and Munc13-1/2/3 TKO cells. The exocytotic burst and sustained release were determined as the $\Delta \mathrm{Cm} 1 \mathrm{~s}$ and $2 \mathrm{~s}$ to $5 \mathrm{~s}$ after the flash, respectively. Error bars indicate standard error of the mean. 
We found that the exocytotic burst and the sustained component were not reduced compared to WT, nor were the release kinetics altered (Figure 10A-C, Table 1), most likely because Munc13-1 and Munc13-2 are able to compensate for the absence of Munc13-3. The postflash $\left[\mathrm{Ca}^{2+}\right]_{\mathrm{i}}$ did not differ between WT and Munc13-3 KO cells (Figure 10A, top).

Lastly, to investigate whether the secretion is completely abolished in cells lacking all three Munc13 isoforms (Munc13-1, -2, and -3), we obtained chromaffin cells from Munc13-1 heterozygous and Munc13-2/3 double homozygous KO background matings. Munc13-1/2/3 TKOs are completely paralyzed, die immediately after birth and look rather similar to Munc13-1/2 DKO mice (Varoqueaux et al., 2002). For the Munc131/2/3 TKO experiments control chromaffin cells were cultured from Munc13-2/3 DKO littermates, which were viable and fertile. We analyzed adrenal chromaffin cells from E18 embryos that were obtained by caesarean section of pregnant females. Compared to Munc13-2/3 double deficient cells, Munc13-1/2/3 triple deficient chromaffin cells showed no significant changes in the exocytotic burst, the sustained component, or in the kinetics of release (Figure 10D-F, Table 1, Figure 10A').

Based on our data, the sustained component in both the Munc13-2/3 DKO and Munc13-1/2/3 TKO cells was reduced by at least $50 \%$ (Figure 20, Figure 10F). Since it is not possible to obtain WT and Munc13-1/2/3 triple deficient mice in the same litter at a frequency that is experimentally feasible, we were unable to accurately assess the contribution of Munc13-3 to LDCV exocytosis. However, taken together, the our data imply that the absence of Munc13-3 seemed to have the smallest effect on LDCV exocytosis, and furthermore, that residual LDCV exocytosis persists in the absence of the three Munc13 isoforms known to regulate neuronal SV exocytosis. 


\subsubsection{Enhanced Exocytosis in Chromaffin Cells from Baiap3 KO Mice}

We first investigated basic properties of exocytosis in mouse adrenal chromaffin cells obtained from P0 Baiap3 KO and WT littermates.

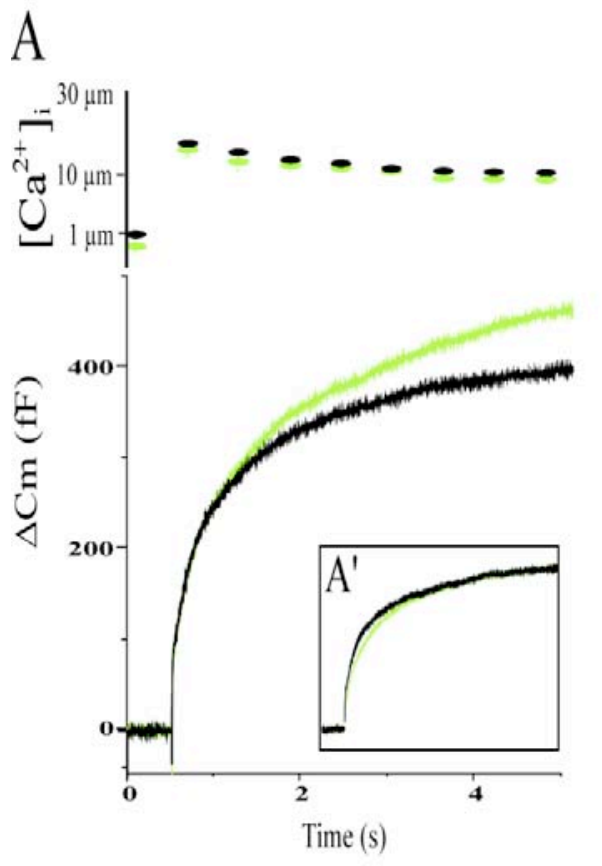

D

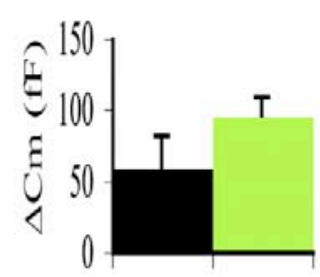

Fast Burst Component

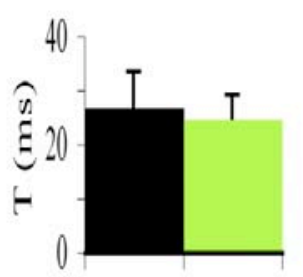

WT

Baiap3 KO

B

Burst

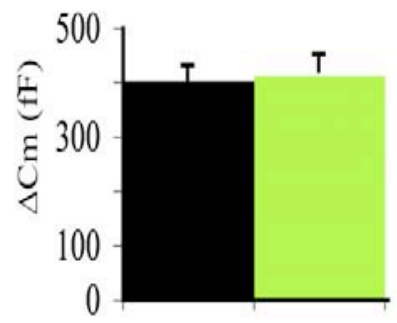

C Sustained

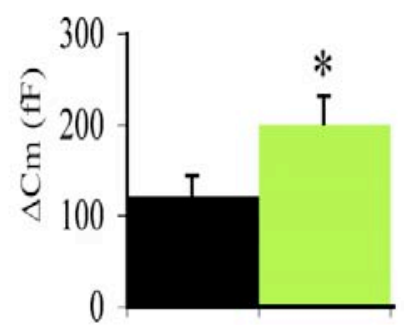

E Slow Burst Component
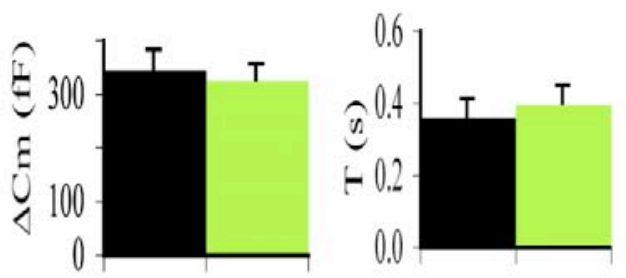

Figure 11. Increased exocytosis in chromaffin cells from Baiap3 deficient mice.

(A) Average $\Delta \mathrm{Cm}$ in response to flash photolysis of NP-EGTA in WT control (27 cells from 6 mice) and Baiap3 KO (28 cells from 6 mice). The intracellular $\mathrm{Ca}^{2+}$ concentration following the flash is shown in the upper trace. (A') The Baiap3 KO trace was normalized to WT amplitude at $4 \mathrm{~s}$ after the flash. (B-C) Comparison of the exocytosis burst and sustained release $(P=0.031)$ in control and Baiap3 KO cells. The exocytotic burst and sustained release were determined as the $\Delta \mathrm{Cm} 1 \mathrm{~s}$ and $2 \mathrm{~s}$ to $5 \mathrm{~s}$ after the flash, respectively. (D-E) Kinetic analysis of the capacitance traces revealed that the two burst components, fast and slow components, are unchanged. Error bars indicate standard error of the mean. *, $P<0.05$; **, $P<$ $0.01 ; * * *, P<0.001$. 
To test whether LDCV exocytosis is regulated by Baiap3, we stimulated chromaffin cells obtained from Baiap3 $\mathrm{KO}$ mice by flash photolysis of caged $\mathrm{Ca}^{2+}$. We found that the sustained component of release was significantly increased by $30 \%$ in Baiap3 deficient cells $(\mathrm{P}=0.031$, Figure $11 \mathrm{C}$ ), whereas the exocytotic burst was unchanged (Figure 11B,D-E). However, normalization of the traces to the sustained component revealed no significant differences in the kinetics of the sustained phase (Figure $11 \mathrm{~A}^{\prime}$ ), which argues against an effect that is specific to the sustained phase. Postflash $\left[\mathrm{Ca}^{2+}\right]_{\mathrm{i}}$ values were similar in $\mathrm{WT}$ and $\mathrm{KO}$ cells, indicating that the increase in sustained exocytosis was not due to differences in $\left[\mathrm{Ca}^{2+}\right]_{\mathrm{i}}$ (Figure $11 \mathrm{~A}$, top).

\begin{tabular}{|c|c|c|c|c|c|c|c|c|}
\hline \multirow[b]{2}{*}{ Mouse lines } & \multirow[b]{2}{*}{ Genotype } & \multirow{2}{*}{$\frac{\text { Burst }}{\mathrm{fF}}$} & \multicolumn{2}{|c|}{$\underline{\text { Fast Burst Component }}$} & \multicolumn{2}{|c|}{$\underline{\text { Slow Burst Component }}$} & \multirow{2}{*}{$\frac{\text { Sustained }}{\mathrm{fF}}$} & \multirow{2}{*}{ No. of cells } \\
\hline & & & $\mathrm{fF}$ & $\overline{\mathrm{ms}}$ & $\mathrm{fF}$ & s & & \\
\hline \multirow{2}{*}{ Munc13-1 } & WT & $432.9 \pm 41$ & $89.2 \pm 8$ & $17.5 \pm 2$ & $343.7 \pm 59$ & $0.38 \pm 0.03$ & $131.4 \pm 16$ & 28 \\
\hline & KO & $267.3 \pm 23$ & $56.7 \pm 7$ & $21.3 \pm 2$ & $210.7 \pm 38$ & $0.28 \pm 0.04$ & $64.9 \pm 9$ & 32 \\
\hline \multirow{2}{*}{ Munc13-2 } & WT & $389.4 \pm 57$ & $39.8 \pm 9$ & $19.7 \pm 1$ & $303.4 \pm 135$ & $0.36 \pm 0.05$ & $96.1 \pm 17$ & 21 \\
\hline & KO & $275.7 \pm 37$ & $23.3 \pm 4$ & $20.0 \pm 2$ & $172.2 \pm 44$ & $0.38 \pm 0.05$ & $59.0 \pm 11$ & 22 \\
\hline \multirow{2}{*}{ Munc13-3 } & WT & $314.2 \pm 52$ & & & & & $111.1 \pm 20$ & 15 \\
\hline & KO & $318.9 \pm 59$ & & & & & $88.1 \pm 14$ & 12 \\
\hline \multirow{2}{*}{ Munc13-1/2 } & $\mathrm{CTL}^{*}$ & $358.2 \pm 42$ & $103.1 \pm 16$ & $17 \pm 1$ & $247 \pm 36$ & $0.35 \pm 0.06$ & $42 \pm 12$ & 12 \\
\hline & DKO & $218.1 \pm 28$ & $60.1 \pm 11$ & $20 \pm 2$ & $140.1 \pm 14$ & $0.26 \pm 0.04$ & $10 \pm 2$ & 14 \\
\hline \multirow{2}{*}{ Munc13-1/2/3 } & $\mathrm{CTL}^{* *}$ & $257.9 \pm 22$ & & & & & $55.7 \pm 18$ & 17 \\
\hline & TKO & $201.7 \pm 33$ & & & & & $27.9 \pm 9$ & 13 \\
\hline \multirow{2}{*}{ Baiap3 } & WT & $402.6 \pm 27$ & $58.4 \pm 8$ & $26.8 \pm 5$ & $344.2 \pm 38$ & $0.41 \pm 0.04$ & $121.3 \pm 21$ & 25 \\
\hline & KO & $420.1 \pm 31$ & $95.2 \pm 15$ & $25 \pm 5$ & $324.8 \pm 32$ & $0.40 \pm 0.04$ & $200.8 \pm 29$ & 22 \\
\hline
\end{tabular}

* Munc13-2 KO as a control for Munc13-12 DKO

** Munc13-23 DKO as a control for Munc13-1/2/3 TKO

Table 1. Comparison of LDCV exocytosis in all KO mouse lines analyzed 


\subsubsection{Depolarization Induced LDCV Exocytosis in Chromaffin Cells from}

\section{Munc13-1/2 DKO and Baiap3 KO Mice}

We have shown that LDCV exocytosis induced by uncaging $\mathrm{Ca}^{2+}$ in Munc13-1/2 DKO cells was drastically reduced in both the exocytotic burst and the sustained component of release. To investigate the effect of Munc13-1 and -2 deletion on LDCV exocytosis in response to a more physiological stimulus, chromaffin cells were stimulated with a voltage protocol consisting of six $10 \mathrm{~ms}$ depolarizations followed by four $100 \mathrm{~ms}$ depolarizations (Figure 12A top). The $10 \mathrm{~ms}$ depolarizations cause the fusion of the IRP, which corresponds to the fraction of the readily releasable vesicles that are closely associated with $\mathrm{Ca}^{2+}$ channels. The subsequent $100 \mathrm{~ms}$ depolarizations elicit fusion of the remainder of the readily releasable pool (RRP), and the IRP and RRP together correspond to the fast component of flash photolysis experiments (Voets et al., 1999). Munc13-2 KO chromaffin cells responded the train of depolarizing stimuli with robust increases in membrane capacitance. In contrast to this, the secretory response was drastically reduced in chromaffin cells from Munc13-1/2 DKO cells. In chromaffin cells deficient for Munc13-1, and -2, exocytosis in response depolarization was significantly reduced. Both the IRP (Figure 12B, $7.7 \pm 2 \mathrm{fF}, P=0.0009$ ) and the RRP (Figure 12C, $55.9 \pm 7 \mathrm{fF}, P=0.0005)$ in Munc13-1/2 DKO cells were reduced compared to Munc13-2 KO cells (Figure 12B, IRP: $33.8 \pm 7 \mathrm{fF}$; Figure 12C, RRP: $108.7 \pm 11 \mathrm{fF}$ ). Measurement of $\mathrm{Ca}^{2+}$ currents did not reveal significant differences between the Munc13-1/2 DKO and Munc13-2 KO chromaffin cells (Figure 12D). The reduction in both the IRP and the RRP is consistent with the reduction in the fast component seen in flash photolysis experiments (Figure 8D). 
A
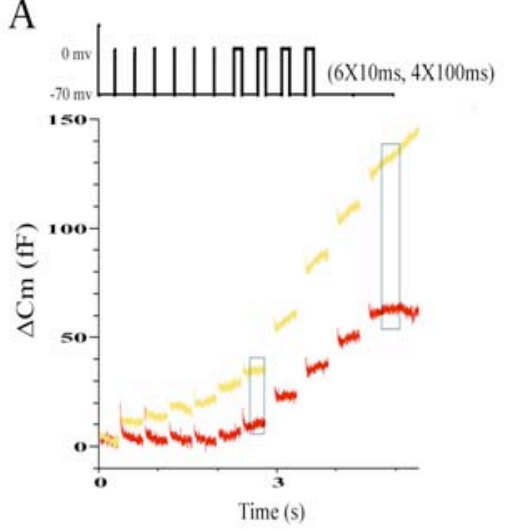

E

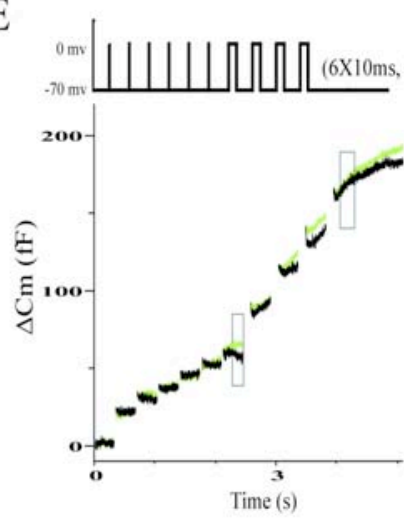

Munc13-2 KO

Munc13-1/2 DKO

\section{B}
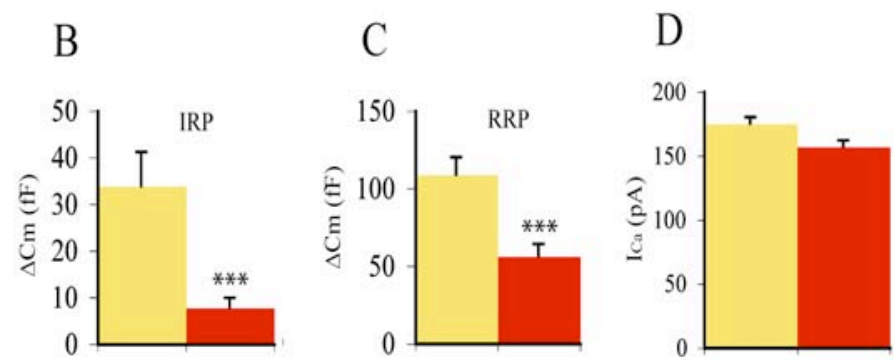

Figure 12. Depolarization induced exocytosis in chromaffin cells from Munc13-1/2

\section{DKO and Baiap3 KO mice.}

(A) Voltage protocol (top) and the resulting average capacitance increase in E18 chromaffin cells from Munc13-2 KO (15 cells from 3 mice, black line) and Munc13-1/2 DKO mice (17 cells from 3 mice, red line). Chromaffin cells were stimulated with trains of short depolarizations, and the $\mathrm{Ca}^{2+}$ current and membrane capacitance were monitored simultaneously before and after stimulation. (B) IRP $(P=0.0009)$, determined as the average capacitance during the time period indicated by the left dashed rectangle in $\mathrm{A}$. (C) RRP ( $P=0.0005)$, determined as the average capacitance during the time period indicated by the right dashed rectangle in A. (D) The average $\mathrm{Ca}^{2+}$ current was identical in the Munc13-2 KO and Munc13-1/2 DKO cells shown in A. (E) Voltage protocol (top) and resulting average capacitance increase in P0 chromaffin cells from WT ( 20 cells from 4 mice, Black line) and Baiap3 KO (32 cells from 4 mice, lime line) mice. Chromaffin cells were stimulated with trains of short depolarizations, and the $\mathrm{Ca}^{2+}$ current and membrane capacitance were monitored simultaneously before and after stimulation. (F) IRP, determined as the average capacitance during the time period indicated by the left dashed rectangle in E. (G) RRP, determined as the average capacitance during the time period indicated by the right dashed rectangle in $\mathrm{E}$. (H) The average $\mathrm{Ca}^{2+}$ current was identical in the WT and Baiap3 KO cells shown in A. Error bars indicate standard error of the mean. *, $P<0.05 ; * *, P<0.01 ; * * *, P<0.001$. 
Since there was no selective reduction of the IRP, Munc13-1 and -2 do not appear to control the docking and priming of vesicles near $\mathrm{Ca}^{2+}$, and our data consistently point to a general role for Munc13-1 and -2 in the docking/priming of vesicles in all release pools.

We also analyzed the response of Baiap3 $\mathrm{KO}$ cells to the depolarization protocol (Figure 12E top). Consistent with the previous finding that after flash photolysis the sustained component, but not the exocytotic burst was increased in Baiap3 KO cells (Figure 11), the voltage protocol consisting of six $10 \mathrm{~ms}$ depolarizations followed by four $100 \mathrm{~ms}$ depolarizations did not reveal any significant differences in the IRP (Figure $12 \mathrm{~F}, 62.4 \pm 7 \mathrm{fF}$ ) and RRP (Figure 12G, $167.9 \pm 14 \mathrm{fF}$ ) of Baiap3 KO cells compared to WT cells (IRP; $55.6 \pm 7 \mathrm{fF}$, RRP; $164.5 \pm 14 \mathrm{fF})$. The $\mathrm{Ca}^{2+}$ currents of Baiap3 KO cells did not differ from those of WT cells (Figure 12E-H).

\subsubsection{Reduced Exocytosis in Chromaffin Cells Overexpressing Baiap3}

To confirm the finding that loss of Baiap3 leads to an increase in the sustained component of release, we examined whether the opposite situation, overexpression of Baiap3, would reduce the LDCV exocytosis. We overexpressed either EGFP or Baiap3 as an IRES (internal ribosome entry site)-EGFP construct with SFV in WT chromaffin cells. Expression of Baiap3 from the viral construct was confirmed by Western blot analysis of Baiap3-SFV infected BHK cells (Figure 13A). Complementary to the increase in exocytosis seen in the absence of Baiap3 (Figure 11), overexpression of Baiap3 resulted in a smaller capacitance change after flash photolysis of caged $\mathrm{Ca}^{2+}$ than overexpression of the EGFP control construct (Figure 13B). 
A

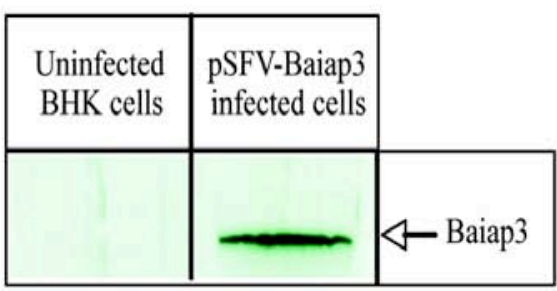

B

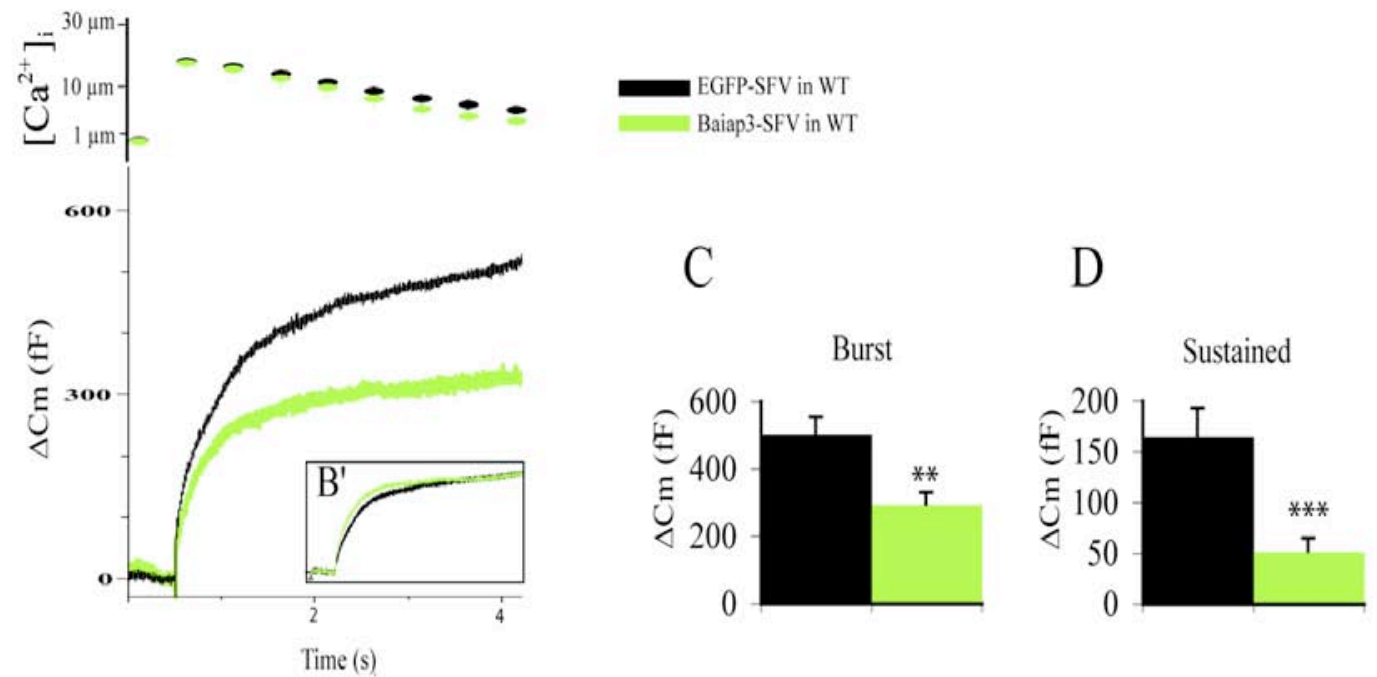

E

F

Fast Burst Component

Slow Burst Component
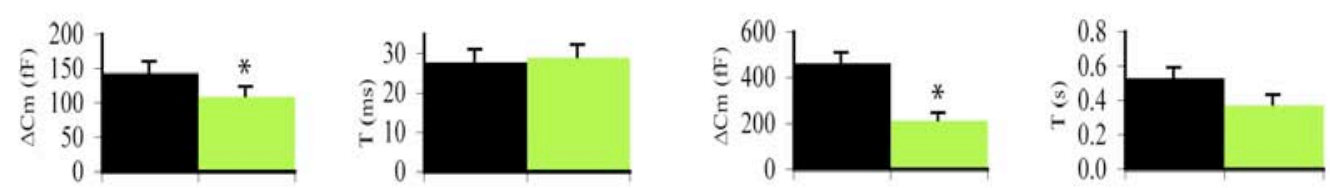

\section{Figure 13. Reduced exocytosis in chromaffin cells overexpressing Baiap3.}

(A) Overexpression of Baiap3-SFV in BHK cells. (B) Average $\triangle \mathrm{Cm}$ in response to flash photolysis of NP-EGTA in P0 EGFP overexpressing WT cells (23 cells from 5 mice) and Baiap3 overexpressing WT cells (24 cells from 5 mice). The intracellular $\mathrm{Ca}^{2+}$ concentration following the flash is shown in the upper trace. (B') The Baiap3 KO trace was normalized to the WT amplitude at $4 \mathrm{~s}$ after the flash. (C-D) Comparison of the exocytotic burst $(P=0.008)$ and sustained release $(P=0.0004)$ in cells overexpressing EGFP and cells overexpressing Baiap3. The exocytotic burst and sustained release were determined as the $\Delta \mathrm{Cm} 1 \mathrm{~s}$ and $2 \mathrm{~s}$ to $5 \mathrm{~s}$ after the flash, respectively. (E-F) Kinetic analysis of the capacitance traces revealed that the two burst components, fast $(P=0.014)$ and slow $(P=0.025)$, are both changed. Error bars indicate standard error of the mean. ${ }^{*}, P<0.05$; **, $P<0.01$; ***,$P<0.001$. 
Overexpression of Baiap3 significantly depressed both the exocytotic burst (Figure $13 \mathrm{C}, 293.3 \pm 34.17 \mathrm{fF}, P=0.008$ ) and the sustained component (Figure 13D, $51.1 \pm 12.8$ $\mathrm{fF}, P=0.0004$ ) in comparison to EGFP overexpressing cells (Figure 13C-D, $500.23 \pm 51$ $\mathrm{fF}$ (Burst), $165.1 \pm 27.2 \mathrm{fF}$ (Sustained)). We found that in the exocytotic burst of Baiap3 overexpressing cells both the fast (Figure 13E, $109.2 \pm 12.1 \mathrm{fF}, P=0.014$ ) and the slow burst (Figure 13F, $209 \pm 34 \mathrm{fF}, P=0.025$ ) were significantly smaller than in EGFP overexpressing cells (Figure 13E-F, $143.4 \pm 16 \mathrm{fF}$ (fast), $463.1 \pm 40 \mathrm{fF}$ (slow)).

The overpexpression of Baiap3 thus has the opposite effect of overexpressing Munc131 (Figure 9). However, like Munc13-1, Baiap3 does not appear to affect the kinetics of the exocytotic burst (Figure 13E-F) or the kinetics of the sustained component (Figure 13B'). Postflash $\left[\mathrm{Ca}^{2+}\right]_{\mathrm{i}}$ was also closely matched between EGFP- and Baiap3 overexpressing cells (Figure 13B, top).

In summary, our data indicate that Baiap3 reduces the number of fusion-competent vesicles and inhibits vesicle recruitment and priming during ongoing release while $\mathrm{Ca}^{2+}$ levels remain high. 


\subsection{Functional Characterizations of Baiap3}

\subsubsection{Basic Characterization of Baiap3 KO Mice}

Baiap3 deficient mice were generated by homologous recombination in mouse embryonic stem cell (Figure 14A). Targeting vector construction and gene targeting in ES cells was done by Dr. Iris Augustin.

A
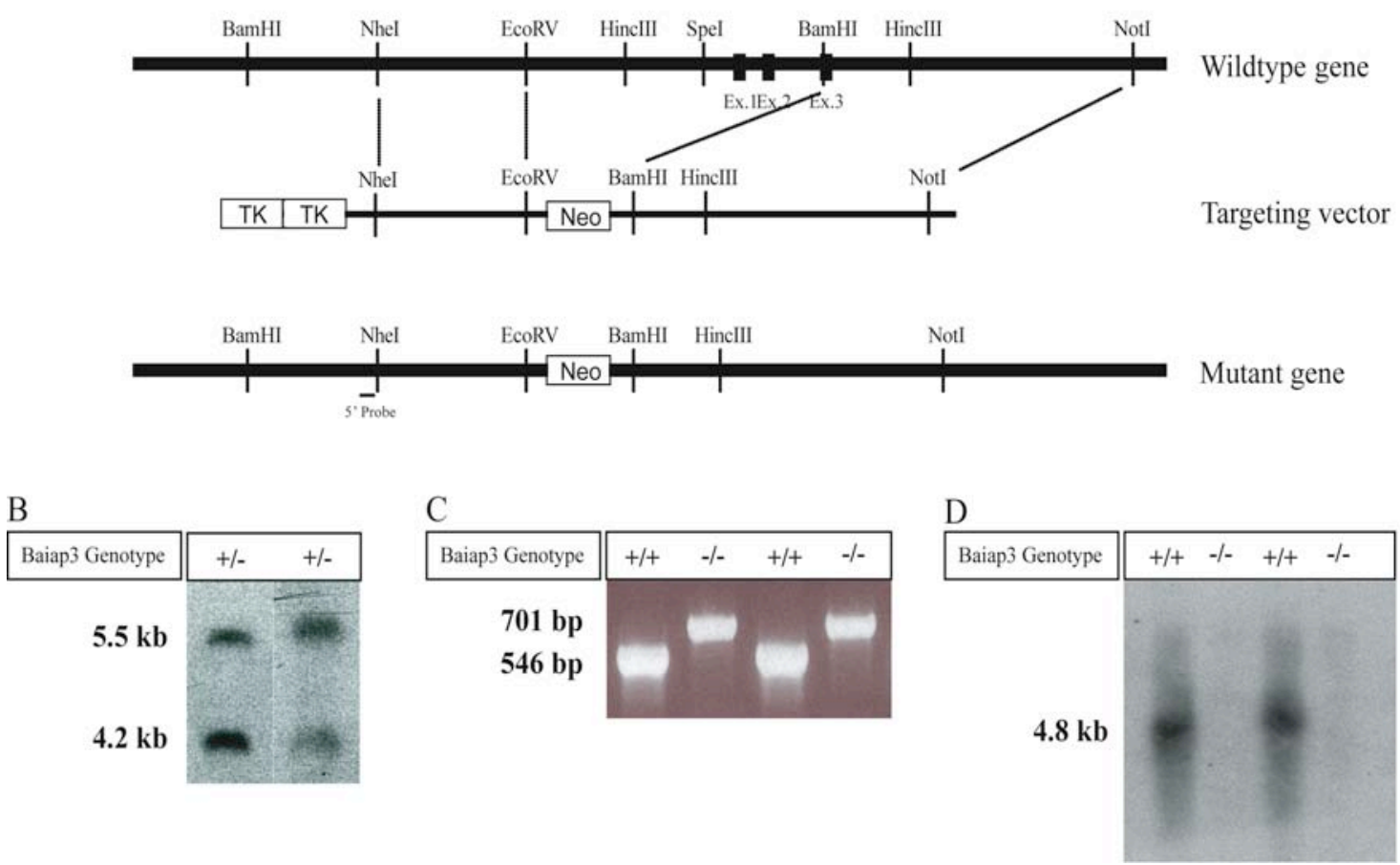

Figure 14. Gene targeting strategy to generate Baiap3 KO mice.

(A) Targeting vector and Baiap3 locus before and after homologous recombination. (B) Genomic Southern blot with an external $5^{\prime}$ probe after BamHI digestion of stem cell DNA. Homologous recombination of the Baiap3 targeting vector results in a shift of a WT $5.5 \mathrm{~kb}$ BamHI fragment to $4.2 \mathrm{~kb}$.

(C) Genomic PCR used for genotyping Baiap3 litters with 546 bp for WT and 636 bp for the KO. (D) Northern blot analysis with a $3^{\prime}$ probe that lies outside the deleted region shows that Baiap3 mRNA is not expressed from the targeted locus. 


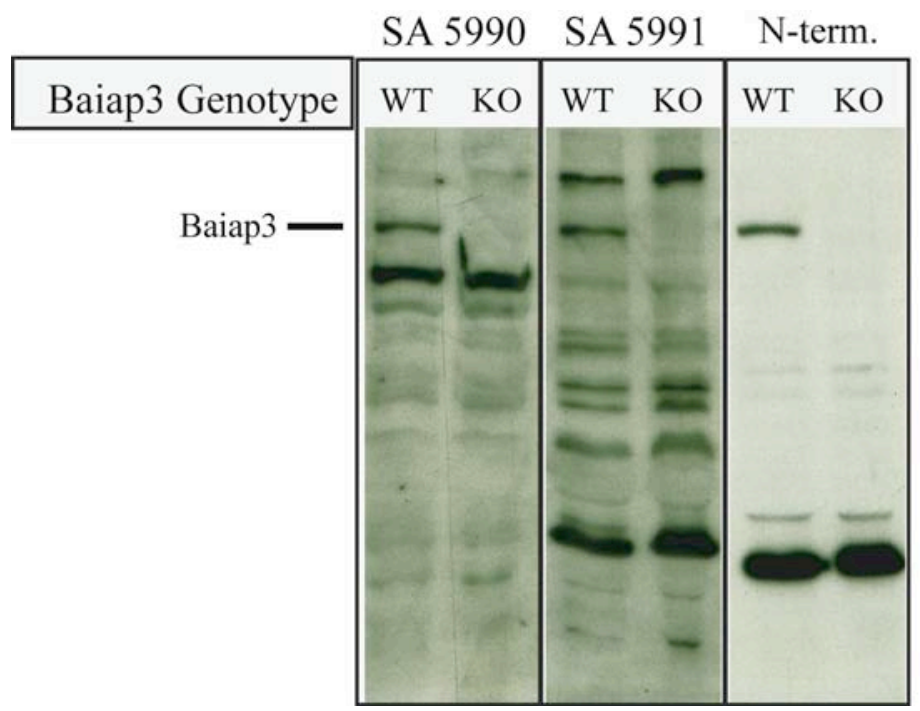

Figure 15. Specificity of Baiap3 antisera.

Specificity of Baiap3 antisera in mouse whole brain from WT and Baiap3 KO mice. SA5990 and SA5991 were generated in rabbit against the MHD to C-terminal region of Baiap3. The antibody against the Nterminus (Dr. Iris Augustin) was also generated in rabbit. All of antisera recognize Baiap3 in WT mice.

Baiap3 KO mice were obtained at the predicted Mendelian frequency. The respective genotypes were initially detected by Southern blotting (Figure 14B), by PCR for routine genotyping (Figure 14C), and by Northern blotting to check for mRNA expression (Figure 14D). Baiap3 KO mice are viable and fertile and show no obvious phenotypic changes in the cage environment. Litter sizes resulting from interbreeding of homozygous Baiap3 deficient animals were indistinguishable from those obtained with WT controls.

To verify Baiap3 protein expression level in WT and Baiap3 KO mice, we generated three polyclonal anti-Baiap3 antisera, which were raised to either the $\mathrm{N}$-terminus or a region of Baiap3 encompassing the MHDs and C-terminus (Figure 15). Western blot analysis of homogenates from whole brain and other tissues showed that Baiap3 protein expression was completely abolished in homozygous Baiap3 KOs (Figure 16B). 
A
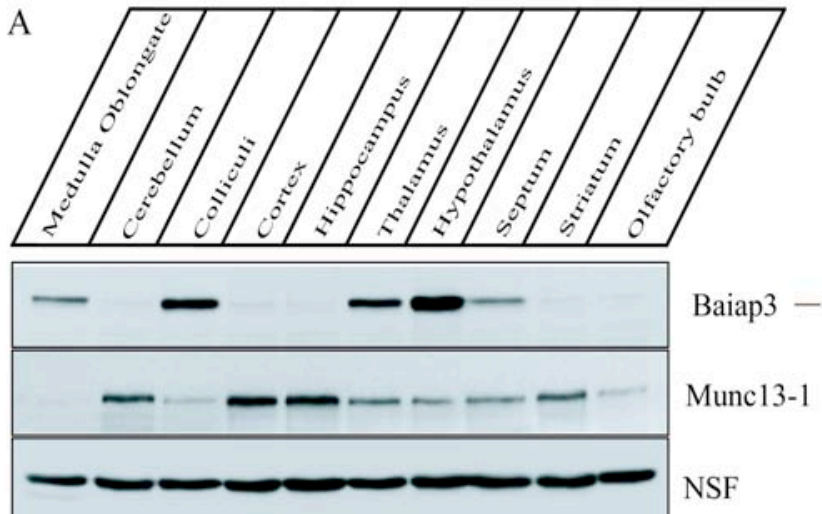

$\mathrm{C}$
B

\begin{tabular}{|c|c|c|c|c|}
\hline Brain & Lung & Spleen & Pancr. & Adrenal \\
\hline$+/+-/-$ & $+/+-/-$ & $+/+-/-$ & $+/+-/-$ & $+/+-/-$ \\
\hline & - \\
\hline
\end{tabular}

$\begin{array}{llllllllllll}\text { E18 } & \text { P1 } & \text { P3 } & \text { P5 } & \text { P7 } & \text { P9 } & \text { P12 } & \text { P15 } & \text { P18 } & \text { P21 } & \text { P90 }\end{array}$

$\begin{array}{lllllllllllllllllll}\text { Hom } & \text { P1 } & \text { S1 } & \text { P2 } & \text { P3 } & \text { S3 } & \text { LP1 } & \text { LS1 } & \text { LP2 } & \text { LS2 } & \text { SPM }\end{array}$

Baiap3

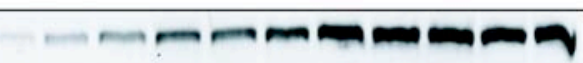

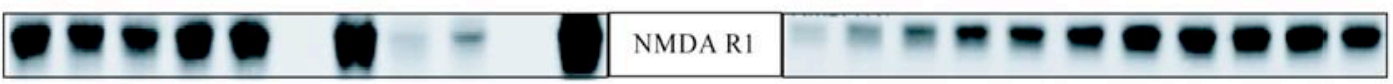

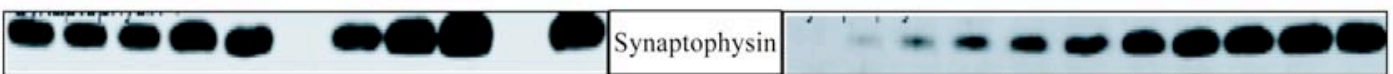

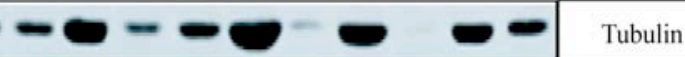

Figure 16. Protein Expression of Baiap3.

(A) Expression of Baiap3 in sub-regions of the brain and (B) brain, lung and adrenal gland. Baiap3 is not expressed in the pancreas and, in contrast to Munc13-4, is absent from spleen. Tissues were homogenized, and the proteins were separated by SDS-PAGE and analyzed by immunoblotting with antibodies to the indicated proteins. (C) Panels on the left show the distribution of Baiap3 in subcellular fractions of brain homogenate. Fractions (10 $\mu \mathrm{g}$ protein per lane) were analyzed by SDS-PAGE and immunoblotting with antibodies to the indicated proteins. Hom, Homogenate; P1, nuclear pellet; P2, crude synaptosomal pellet; P3, light membrane pellet; LP1, lyzed synaptosomal membranes; LP2, crude synaptic vesicle fraction; SPM, synaptic plasma membranes; S1, supernatant after synaptosome sedimentation; S3, cytosolic fraction; LS1, supernatant after LP1 sedimentation; LS2, cytosolic synaptosomal fraction. Panels on the right show the expression of Baiap3 during development from E18 to P90 (Dr. Iris Augustin). Immunoblotting was done with antibodies to the indicated proteins.

The absence of Baiap3 expression did not affect the protein levels of any of the proteins involved in vesicle exocytosis that we investigated (Figure 17A). These included other members of the Munc13 protein family (Munc13-1, -2, and -3), SNARE 
core complex components (Syntaxin, SNAP-25, and Synaptobrevin), and the SNARE regulatory protein Munc18 (Figure 17A). In order to determine where in the brain Baiap3 is expressed, we performed Western blot analysis on sub-regions of the brain. Baiap3 expression is most prominent in the hypothalamus, thalamus, colliculi, septum and in the brain stem. Unlike Munc13-1 and Munc13-2, Baiap3 is not strongly expressed in hippocampus (Figure 16A). To study developmental regulation and subcellular distribution of Baiap3 protein in WT mice, we analyzed the expression level by Western blotting. The expression level of Baiap3 was very low at E18 and increased during postnatal development to reach a plateau at P12-P18 (Figure 16C). In the subcellular fractionation, Baiap3 was enriched in the crude synaptic vesicle fraction (LP2). However, unlike Munc13-1 and NMDA R1 (the postsynaptic density component marker), Baiap3 is not enriched in synaptic plasma membrane (SPM) (Figure 16C).

Among the Munc13 family members, Munc13-4 is the isoform most closely related to Baiap3 (Koch et al., 2000). However, unlike the other Munc13s and Baiap3, Munc13-4 is not expressed in neurons. Like Munc13-4, Baiap3 is also expressed in lung and adrenal gland (Figure 16B). Furthermore, we found that Munc13-1, -2, -3 and Baiap3 are expressed in mouse adrenal gland (Figure 17A). We did not detect any alterations in the expression levels of Munc13 isoforms and SNARE core complex components in Baiap3 deficient adrenal glands. The expression level of Chromogranin A, an LDCV marker, was also not changed (Figure 17A). Baiap3 was initially identified as a binding partner BAI1 in a yeast two-hybrid screen (Shiratsuchi et al., 1998). The significance of this interaction has not been determined and we found no alteration of the BAI1 protein expression level in Baiap3 KO brain homogenate (Figure 17A). 
A

\begin{tabular}{|c|c|c|c|}
\hline \multirow[b]{2}{*}{ Baiap3 Genotype } & Whole Brain & & Adrenal Gland \\
\hline & WT $\quad$ KO & & WT $\quad$ KO \\
\hline & 6 & Munc13-1 & $=$ \\
\hline & $\mathrm{El}^{2}$ & bMunc13-2 & $=$ \\
\hline & 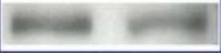 & Munc13-3 & 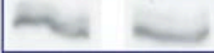 \\
\hline & $=0$ & Munc18 & 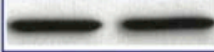 \\
\hline & 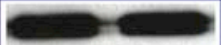 & Syntaxin-1A/B & $=$ \\
\hline & & SNAP-25 & \\
\hline & $m$ & Synaptobrevin-2 & - \\
\hline & $\rightarrow$ & Tubulin & 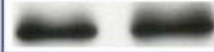 \\
\hline & & ChromograninA & C \\
\hline & 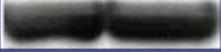 & BAI 1 & \\
\hline
\end{tabular}

B

\begin{tabular}{|c|l|}
\cline { 2 - 2 } \multicolumn{1}{c|}{} & \multicolumn{2}{c|}{ Whole Brain } \\
\hline Munc13 Genotype & WT $\quad$ DK0 \\
\hline \hline Baiap3 & \\
\hline \hline Tubulin & \\
\hline
\end{tabular}

\section{Figure 17. Immunoblot analysis of adult whole brain and adrenal gland.}

(A) Expression of SNARE complex components and SNARE regulatory proteins in whole brain and adrenal gland from WT and Baiap3 KO mice. (B) Expression of Baiap3 protein in whole brain of Munc13 DKO and WT mice. Whole brain and adrenal glands from mice were homogenized, and protein (10 $\mu \mathrm{g}$ for brain, and $20 \mu \mathrm{g}$ for adrenal gland per lane) was analyzed by SDS-PAGE and immunoblotting with antibodies to the indicated proteins.

We also checked whether Baiap3 expression might be altered in the absence of Munc13-1 and -2, but found not differences of Baiap3 protein levels between WT and Munc13-1/2 DKO brains (Figure 17B). While Baiap3 shows a more restricted expression level in the brain than Munc13-1 and Munc13-2, Baiap3 and Munc13-1, -2, and -3 are coexpressed in mouse adrenal gland, and, based on the electrophysiological analysis of the adrenal chromaffin cells, all serve to regulate LDCV exocytosis. 


\subsubsection{Baiap3 Binds to Both Munc13-1 and Syntaxin 1}

Munc13s are essential regulators of SNARE-mediated exocytosis of SVs. Munc13-1 binds not only Syntaxin 1 but also other SNARE core components (Betz et al., 1997). In order to determine whether Baiap3 also bound to SNARE core complex components we performed co-sedimentation assays by using recombinant GST fusion protein constructs. GST-Syntaxin-1A was able to bind not only Munc13-1, but also bound Baiap3 in co-sedimentation assays performed with recombinant Munc13-1 or Baiap3 expressed in HEK 293FT cells (Figure 18A).

A

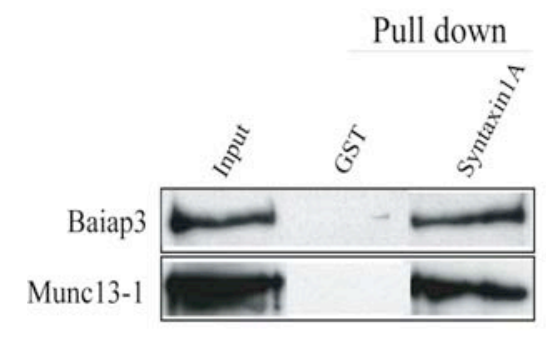

B

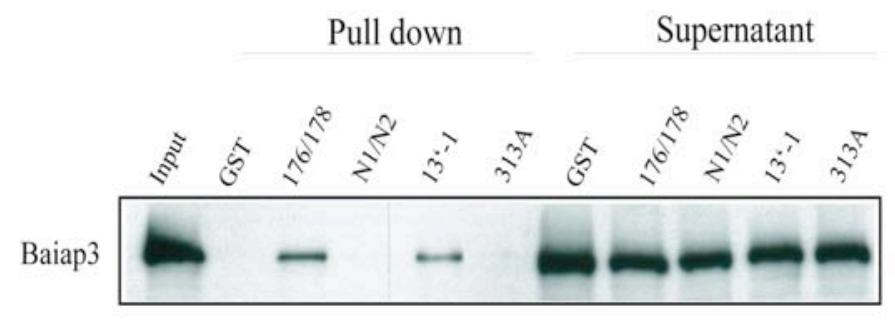

$\mathrm{C}$

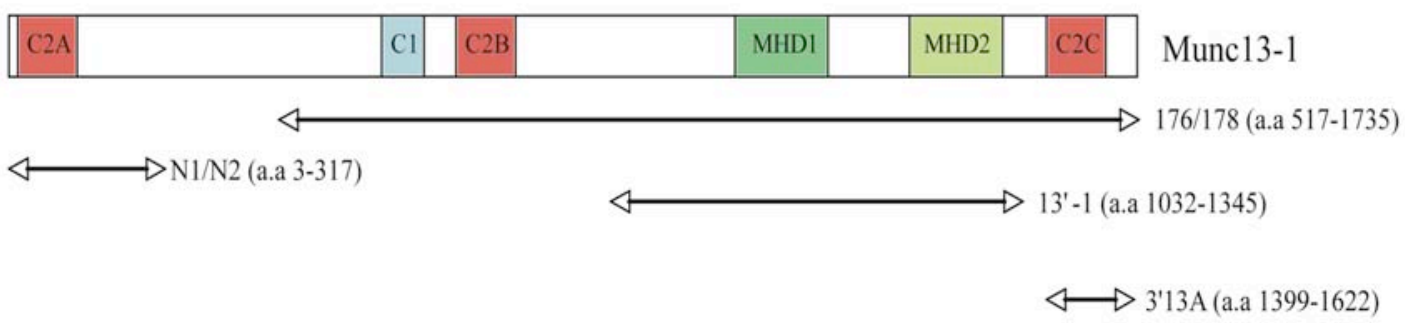

Figure 18. Baiap3 binds to Syntaxin and the MHDs of Munc13-1.

(A) Representative co-sedimentation assays of GST-fused-Syntaxin 1A (a.a.1-276) and of GST alone with Baiap3 or Munc13-1 produced in HEK293FT cells. Munc13-1 was used as a positive control for Syntaxin binding and HEK 293FT cells were transfected with either MYC-Baiap3 or EGFP-Munc13-1. (B) Representative co-sedimentation assays of several GST-fused Mun13-1 fragments and of GST alone with Baiap3 produced in HEK293FT cells. (C) Domain structure of Munc13-1 and representation of GST-Munc13-1 fusion constructs; pGEX-Munc13-1-176/178 (a.a 517-1735), pGEX-Munc13-1-N1/N2 (a.a 3-317), pGEX-Munc13-1-13'1 (a.a 1032-1345), and pGEX-Munc13-1-3'13A (a.a 1399-1622). 


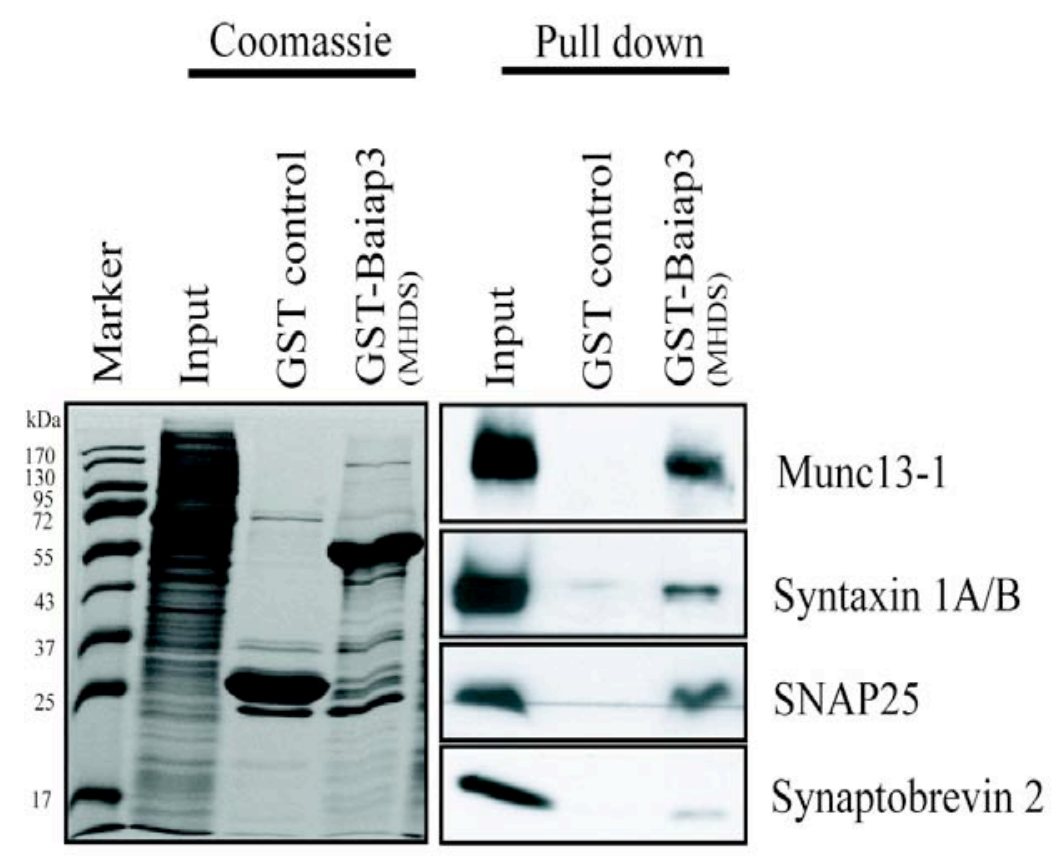

Figure 19. Binding of SNARE complex core components and Munc13-1 to a recombinant Baiap3 fragment encompassing the MHDs.

GST-Baiap3-MHDs-fusion protein and GST alone as a control were used for cosedimentation assays. Binding of Syntaxin 1A/B, SNAP-25, Synaptobrevin 2 and Munc13-1 was assayed by SDS-PAGE, and immunoblotting.

To determine whether Baiap3 also interacts with Munc13-1, we used recombinant protein fragments of Munc13-1. Recombinant GST-Munc13-1 fusion fragments (Betz et al., 1997; Figure 18C) were used in co-sedimentation assays with cell lysate from HEK293FT cells expressing Baiap3, and bound material was assayed for by immunoblotting. Two Munc13-1 constructs, pGEX-Munc13-1-176/178 (a.a 517-1735) and pGEX-Munc13-1-13'1 (a.a 1032-1345), were capable of binding to Baiap3 (Figure 18B). The overlapping regions of the two constructs contain the MHDs of Munc13-1, a region that is also involved in binding Syntaxin $1 \mathrm{~A}$. 
To test whether Baiap3 is also able to bind Syntaxin and Munc13-1 in a more native context, we used a GST-Baiap3-MHDs fusion protein in a co-sedimentation assay with mouse whole brain homogenate. The GST-Baiap3-MHDs construct pulled down not only Munc13-1 but also SNARE core complex components (Syntaxin 1A/B, SNAP-25 and Synaptobrevin 2) (Figure 19).

These data indicate that Baiap3 interacts with Syntaxin 1 and Munc13-1, and may be associated with the SNARE core complex by binding to Syntaxin 1 and/or Munc13-1. In these experiments, we attempted to use recombinant soluble Baiap3. However, Baiap3 fragments containing the MHD domains are highly insoluble when expressed in E. coli, and Baiap3 expressed in HEK293FT cells was mostly recovered in the detergent insoluble membrane fraction and we could not obtained a soluble sample of Baiap3. We do not know whether the detergent insolubility of Baiap3 overexpressed in cells was due to the formation of insoluble aggregates or its association with cytoskeletal elements. 


\section{Discussion}

This is the first study to systematically investigate the role of the Munc13 protein family in LDCV exocytosis. We found that Munc13-1, Munc13-2, which were known to be essential positive regulators of SNARE-mediated exocytosis of neuronal SVs, also control LDCV exocytosis in chromaffin cells. Remarkably, one member of this protein family, Baiap3, seems to suppress LDCV exocytosis in chromaffin cells, making Baiap3 the first Munc13 homologue for which a negative regulatory function in exocytosis has been described.

\subsection{Munc13s are Positive Regulators of LDCV Exocytosis}

Munc13s are essential for the exocytosis of neuronal SVs in invertebrates as well as in mammals (Augustin et al., 1999b; Varoqueaux et al., 2002; Richmond et al., 1999; Aravamudan et al., 1999). However, their physiological role in mammalian LDCV exocytosis had previously only been examined by overexpression of either Munc13-1 or Munc13-2 in WT chromaffin cells (Ashery et al., 2000; Stevens et al., 2005; Zikich et al., 2008). The three Munc13 isoforms whose role in neuronal SV exocytosis has been established, Munc13-1, -2 and -3, are also found in bovine chromaffin cells (Ashery et al., 2000; Zikich et al., 2008) and in mouse adrenal gland (Figure 17). To examine the role of endogenous Munc13s in $\mathrm{Ca}^{2+}$ triggered LDCV exocytosis, we studied exocytosis in chromaffin cells taken from Munc13-1, -2, -3 and Baiap 3 deficient mice, using flash photolysis of caged $\mathrm{Ca}^{2+}$. Flash photolysis protocols cause a sudden uniform increase in the concentration of intracellular $\mathrm{Ca}^{2+}$ throughout the cell, triggering an exocytotic burst of LDCV release that is followed by a slower, sustained component of release. The 
burst component consists of those vesicles that were already in a fusion competent, i.e. docked and primed state, at the time of the stimulus, whereas the sustained component consists of vesicles that undergo $\mathrm{Ca}^{2+}$-dependent docking, priming and release while $\mathrm{Ca}^{2+}$ levels remain high (Neher, 2006). However, the pool of vesicles released in the burst phase and those released during the sustained phase are a continuous pool of vesicles in the sense that they need to go through the same maturations steps, i.e. docking and priming prior to release.

Among the four mouse lines studied, the most drastic reduction of release seen in the absence of a single Munc13 isoform, was detected in the Munc13-1 deficient chromaffin cells. Without Munc13-1, the secretory burst was reduced by $40 \%$ and the sustained component by 50\% (Figure 6, Figure 20). In Munc13-2 deficient chromaffin cells, the reduction of the burst phase and the sustained phase was only $30 \%$ and $40 \%$, respectively, which was statistically not significant (Figure 7, Figure 20). However, in chromaffin cells lacking both Munc13-1 and -2, the reduction in burst and sustained release was greater than in both single knockouts, indicating that Munc13-2 also functions to regulate LDCV exocytosis (Figure 8, Figure 20). The absence of Munc13-3 on the other hand, had no significant effect on either the burst or sustained phase of release (Figure 10, Figure 20). In addition to the distinction between the burst phase of release and the sustained phase, analysis of the kinetics of release during the burst phase reveals the presence of a slow and a fast burst components, which is thought to represent different states of the fusion machinery that translate into differences in the "readiness" of docked and primed vesicles to fuse (Neher, 2006). The state of the fusion machinery that is responsible for the slow burst seems to be a precursor of the configuration that mediates the fast burst (Voets et al. 1999). Since Munc13s are thought to function in the docking/priming of vesicles, their absence should affect both 
the fast and the slow burst components, as is the case for most manipulations of the size of the burst pool (Neher 2006). In line with this assumption, in Munc13-1 and Munc131/2 DKO cells, i.e. those genotypes with a significant reduction in the exocytotic burst, both the slow and the fast burst component were reduced, without any significant change in the time constants (Figure 6D,E and Figure 8D,E).

Our study is the first report of a deficit in LDCV exocytosis from chromaffin cells in Munc13 deficient animals, and establishes that endogenous Munc13-1 and Munc13-2 regulate LDCV exocytosis in chromaffin cells. Since both the burst and the sustained component of release were reduced, without any change in their kinetics (Figures 6-8) our data are best explained by a model in which Munc13-1 and -2, in principle, have equivalent roles as docking/priming factors in establishing the pool of release ready vesicles (vesicles released during the burst phase) and in the $\mathrm{Ca}^{2+}$-dependent docking/priming of new LDCVs during the sustained phase of release. Munc13-1 may be more efficient in mediating the docking/priming process, its absence thus having the greatest effect. However, the apparent differences in priming efficiency between Munc13-1, -2 and -3 could of course also be due to differences in the level of protein present in chromaffin cells. Unfortunately, we were not able to compare proteins levels directly, because the amount of protein that could be obtained from cultured chromaffin cells was too low, and whole adrenal glands also contain synapses, presumably with unknown amounts of different Munc13 isoforms. Somewhat surprisingly, while deletion of Munc13-1 and -2 completely eliminates SV exocytosis in cultured hippocampal neurons (Augustin et al., 1999b; Varoqueaux et al., 2002), LDCV exocytosis was not completely abolished even in the absence of Munc13-1 -2 and -3 (Figure 10D-F). Munc13-independent neurotransmitter release has however been described for the neuromuscular junction (Varoqueaux et al., 2005). In chromaffin cells, docking and 
priming of LDCVs therefore appears to involve other regulatory proteins, whose identity and function of remains to be investigated. Potentially Caps proteins, which are involved in SVs exocytosis in mammalian neurons (Jockusch et al., 2007) as well in LDCV exocytosis in chromaffin cells (Elhamadani et al., 1999; Liu et al., 2008) and in C. elegans (Speese et al., 2007, Zhou et al., 2007) could be responsible for the residual LDCV release in the absence of Munc13s. Yet, Caps and Munc13 do not perform the same function in the docking/priming reaction, since overexpression of one does not rescue the phenotype seen in the absence of the other (Jockusch et al., 2007), which argues against this theory. Two other obvious candidates that might be responsible for LDCV exocytosis in the Munc13-1, -2, -3 TKOs, would be the two remaining members of the Munc13 protein family, Munc13-4 and Baiap3. However, we were unable to detect Munc13-4 in adrenal gland by Western blotting (data not shown), and based on our analysis of the role of Baiap3 in chromaffin cells, Baiap3 is a negative rather than a positive regulator of LDCV exocytosis.
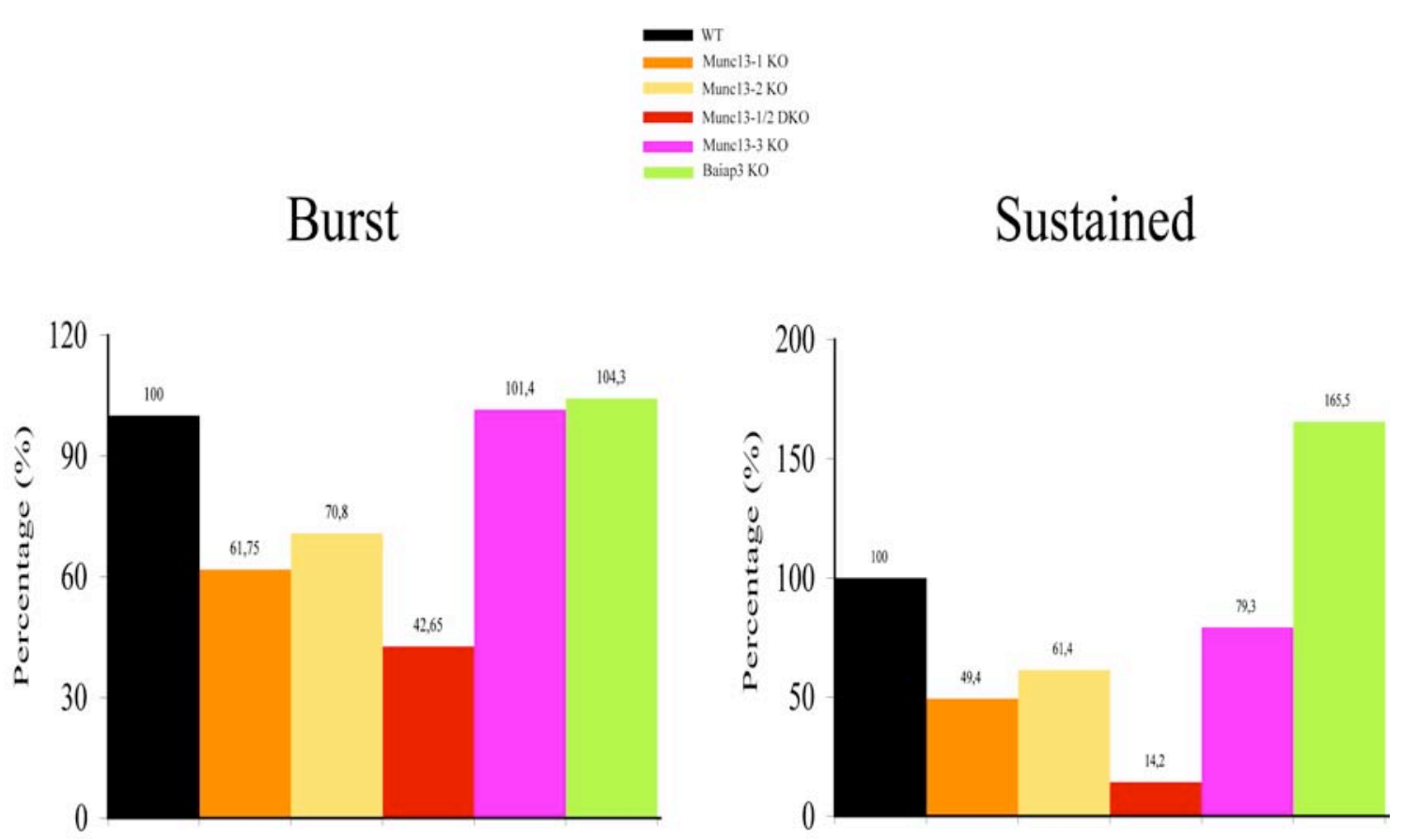

Figure 20. Relative amplitude sizes of the burst and sustained phases of LDCV exocytosis in the absence of Munc13-1, Munc13-2, Munc13-1/2, Munc13-3 and Baiap3. 


\subsection{Baiap3/Bap3 is a Negative Regulator of LDCV Exocytosis.}

Baiap3 was first identified and named as a binding partner of the brain specific angiogenesis inhibitor I (BAI1), which encodes a seven span transmembrane protein, which belongs to the adhesion-type G-protein-coupled receptor family (Shiratsuchi et al., 1998). Evolutionarily, Baiap3 appears the be related to Munc13s, its domain structure is homologous to the Munc13 C-terminal half which features two Munchomology-domains (MHDs) flanked by C2 domains (Shiratsuchi et al., 1998; Koch et al., 2000). Based on sequence similarity, the closest relative of Baiap3 is the nonneuronal isoform Munc13-4 (Figure 21; Table 2; Koch et al., 2000), which is essential for exocytosis of secretory granules from cells of the hematopoietic lineage (Feldmann et al., 2003; Neeft et al., 2005).

Because all Munc13 isoform whose function had been analyzed previously were found to be positive regulators of SNARE-mediated exocytosis, we were surprised to discover that LDCV exocytosis was in fact enhanced, rather than reduced in the absence of Baiap3 (Figure 11). Conversely, when we overexpressed Baiap3 in WT chromaffin cells, LDCV exocytosis was dampened, indicating that Baiap3 negatively regulates LDCV exocytosis (Figure 13). In flash photolysis experiments using Baiap3 KO chromaffin cells, only the sustained component was increased, whereas overexpression suppressed both the burst and the sustained component of release. This suggests that Baiap3 suppresses both the pre-burst docking/priming of vesicles and the recruitment of new vesicles at elevated $\mathrm{Ca}^{2+}$ levels. 
A

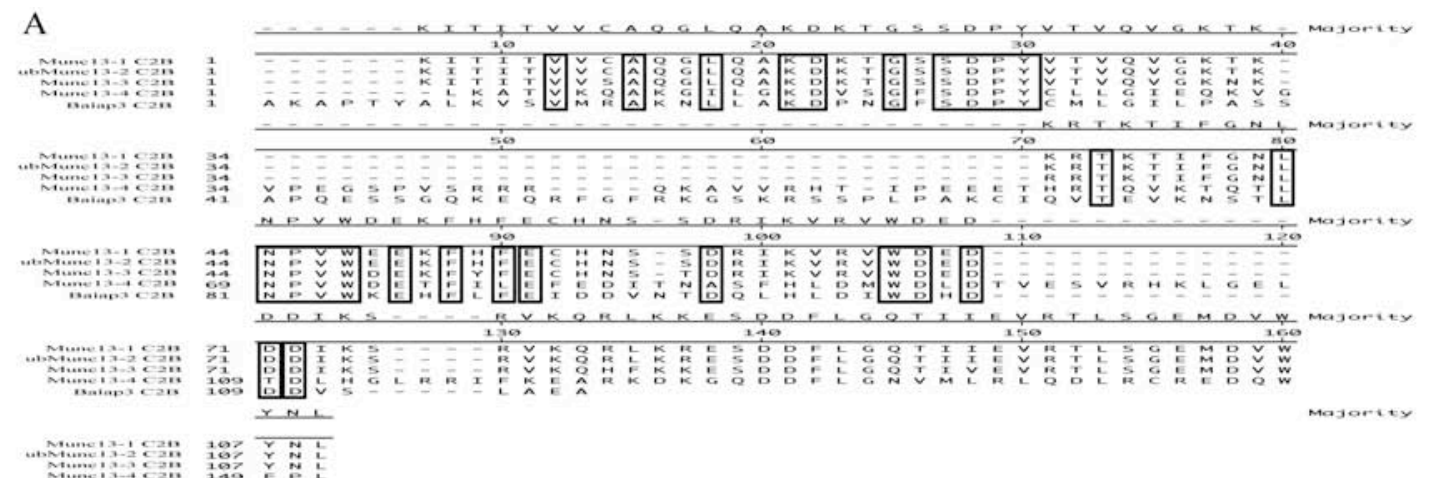

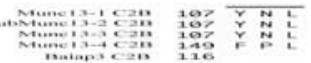

B

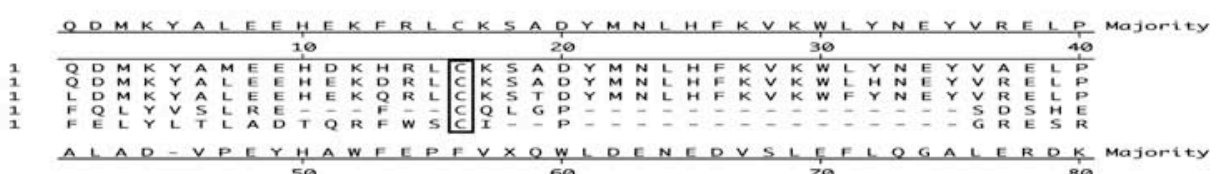

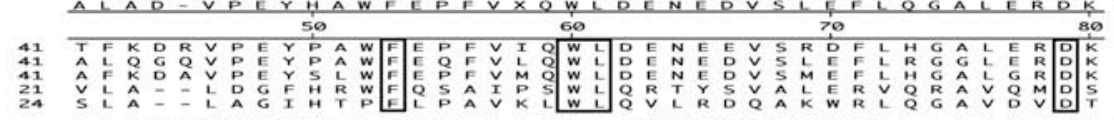

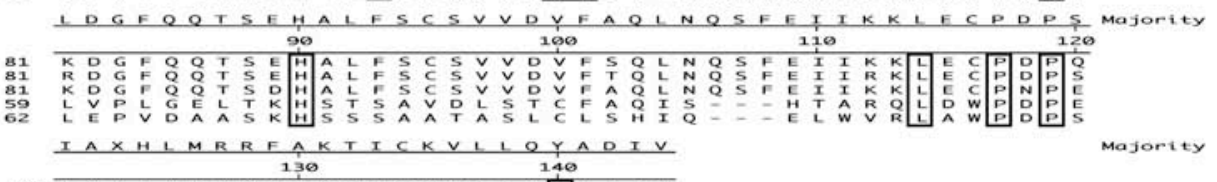

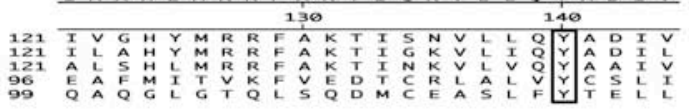

$\mathrm{C}$

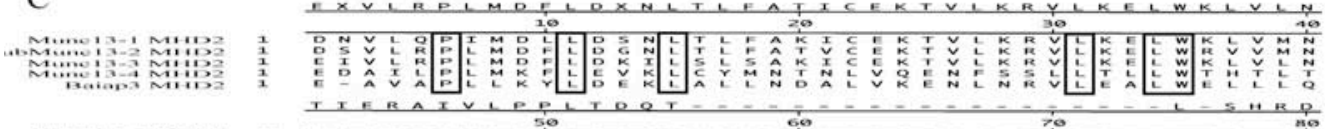

M.M.

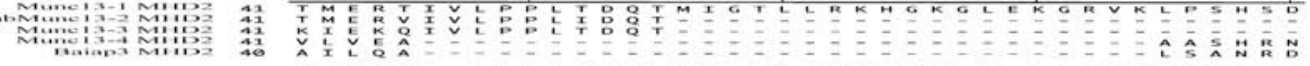

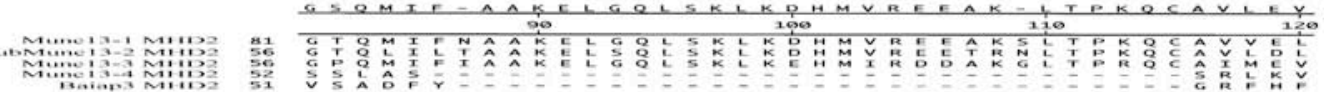

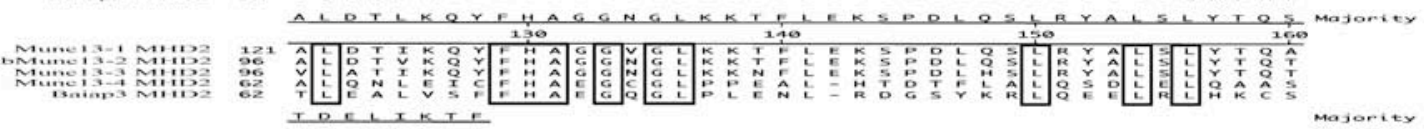

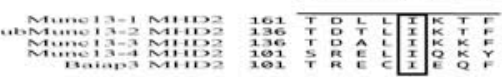

$\mathrm{D}$

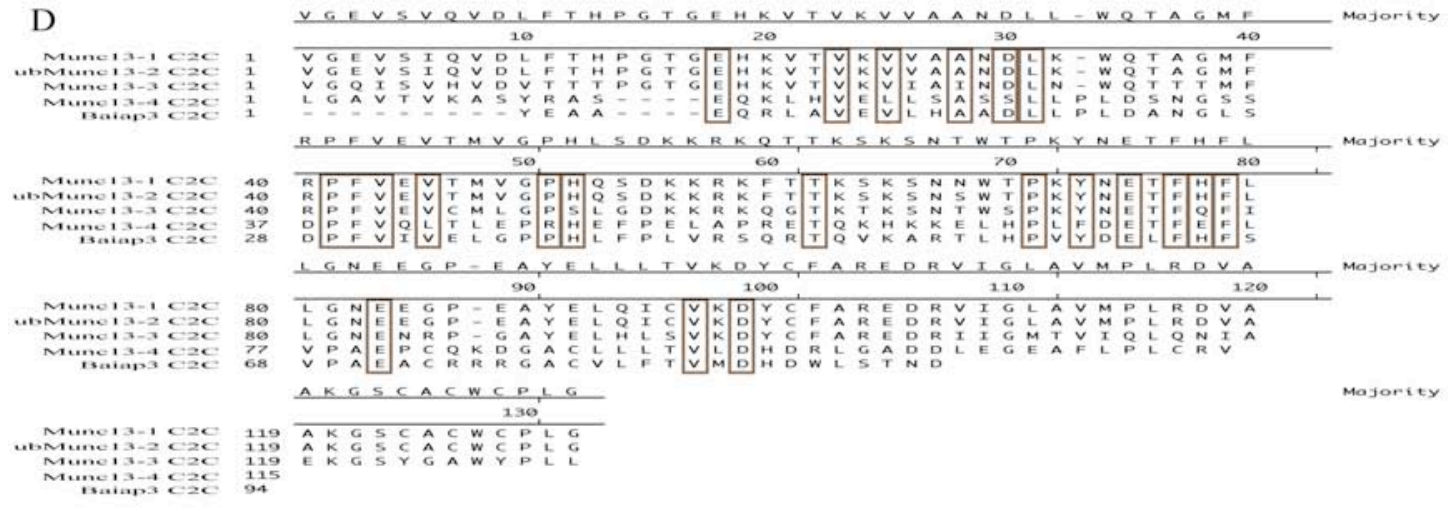

Figure 21. Protein Sequence Comparison of the C2 domains and the MHDs of Munc13 isoforms and Baiap3. 


\begin{tabular}{|c|c|c|c|c|c|}
\hline & VS & Munc13-2 & Munc13-3 & Munc13-4 & Bap3 \\
\hline \multirow{5}{*}{ Munc13-1 } & C2B & $\begin{array}{c}100 \% \\
(109 / 109)\end{array}$ & $\begin{array}{c}90.8 \% \\
(99 / 109)\end{array}$ & $\begin{array}{c}31.2 \% \\
(34 / 109)\end{array}$ & $\begin{array}{c}15.6 \% \\
(17 / 109)\end{array}$ \\
\cline { 2 - 6 } & MHD1 & $\begin{array}{c}81.3 \% \\
(117 / 144)\end{array}$ & $\begin{array}{c}79.9 \% \\
(115 / 144)\end{array}$ & $\begin{array}{c}13.2 \% \\
(19 / 144)\end{array}$ & $\begin{array}{c}14.6 \% \\
(21 / 144)\end{array}$ \\
\cline { 2 - 6 } & MHD2 & $\begin{array}{c}70.8 \% \\
(119 / 168)\end{array}$ & $\begin{array}{c}64.9 \% \\
(109 / 168)\end{array}$ & $\begin{array}{c}13.7 \% \\
(23 / 168)\end{array}$ & $\begin{array}{c}17.3 \% \\
(29 / 168)\end{array}$ \\
\cline { 2 - 6 } & C2C & $\begin{array}{c}99.2 \% \\
(129 / 130)\end{array}$ & $\begin{array}{c}66.2 \% \\
(86 / 130)\end{array}$ & $\begin{array}{c}23.1 \% \\
(30 / 130)\end{array}$ & $\begin{array}{c}21.5 \% \\
(28 / 130)\end{array}$ \\
\hline
\end{tabular}

Table 2. Percent identity of the domain structure of Munc13s and Baiap3.

To further analyze the effect of Munc13-1/2 and Baiap3 on the release-ready vesicle pool, we also stimulated Munc13-1/2 DKO and Baiap3 KO cells by depolarization. Depolarization protocols do not lead to the sudden uniform increase in the intracellular $\mathrm{Ca}^{2+}$ concentration achieved by flash photolysis, because the $\mathrm{Ca}^{2+}$ enters the cell via voltage gated $\mathrm{Ca}^{2+}$ channels, allowing the experimental distinction between vesicles docked in the vicinity of $\mathrm{Ca}^{2+}$ channels and those docked at a greater distance based on their release kinetics (Schneggenburger and Neher, 2005). The immediately releasable pool (IRP) seen with depolarization is thought to represent those vesicles docked/primed closest to the $\mathrm{Ca}^{2+}$ channels, they are also released during the fast burst in flash photolysis experiments, but due to the uniform increase in intracellular $\mathrm{Ca}^{2+}$ do not show up as a separate pool (Voets et al., 1999). According to the model of LDCV exocytosis refined by Voets and colleagues (1999), the relationship between the vesicle pools mobilized by depolarization and by those release after flash photolysis is as follows: The IRP and the readily releasable pool (RRP) of vesicles released by depolarization together correspond to the fast burst pool of flash photolysis experiments 
(Figure 22), whereas the vesicles of the slow burst component and those of the sustained component are not released in response to our depolarization protocol.

Baiap3 KO cells, which showed no reduction in the fast or slow burst component after flash photolysis, also showed no deficit in the IRP or RRP released in response to depolarization (Figure 12E-H). Munc13-1/2 deficient cells on the other hand, which did have a deficit in the slow and the fast burst phase in responses to flash photolysis, also showed a deficit in the IRP and RRP exocytosis elicited by depolarization (Figure 12AD). Thus, neither Baiap3 nor Munc13-1 and Munc13-2 appear to be essential for selective docking/priming of vesicles in close vicinity of $\mathrm{Ca}^{2+}$ channels.

Taken together, our analyses of Munc13 and Baiap3 deficient chromaffin cells suggest that Baiap3 functions as a negative regulator of the same steps in LDCV exocytosis that are facilitated by Munc13-1 and Munc13-2. The fact that the exocytotic burst was not affected in Baiap3 KO cells, but suppressed when Baiap3 was overexpressed, can be explained if endogenous Baiap3 levels are not high enough to interfere with the establishment, i.e. docking and priming, of a WT-sized pool of vesicles when the cell has not been stimulated, but sufficiently high to impair the recruitment of new vesicles at times of high demand, i.e. during ongoing release. We therefore propose a model in which Baiap3 acts as an antagonist in the docking/priming reaction that requires Munc13-1 and Munc13-2 and is necessary to establish the release ready pool of vesicles as well as their $\mathrm{Ca}^{2+}$ stimulated re-supply (Figure 22). 


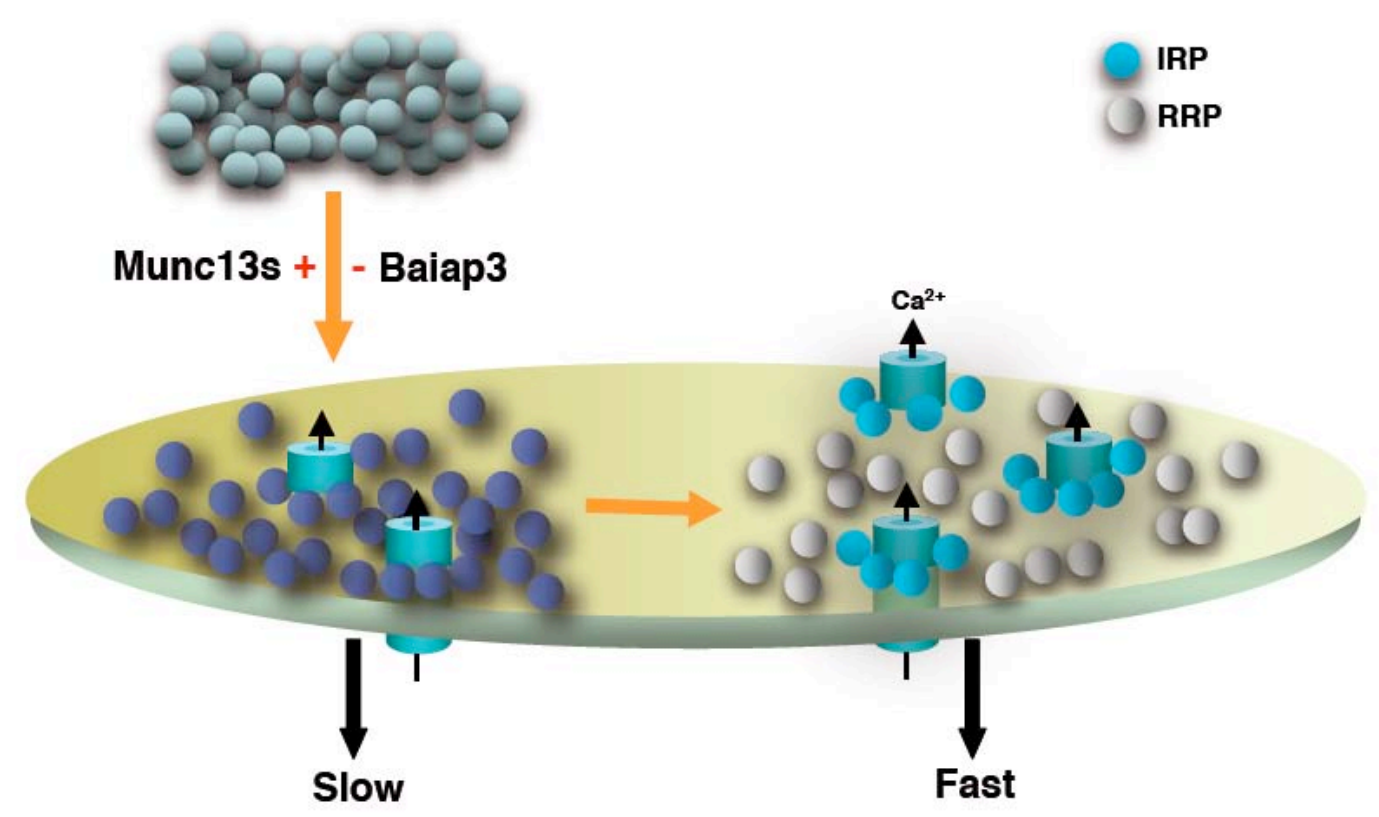

Figure 22. Munc13s and Baiap3 control LDCV exocytosis. Munc13s are positive regulators and Baiap3 a negative regulator in recruiting LDCVs for release and thus function upstream of both the slow and the fast pool of release-ready vesicles.

\subsection{Munc13s and Baiap3 as Regulators of SNARE-Mediated}

\section{Exocytosis}

The docking and priming reactions that occur before a vesicle reaches fusion competence require SNARE proteins and SNARE regulatory proteins like Munc13 and Munc18 (Augustin et al., 1999b; Jahn and Scheller, 2006; Varoqueaux et al., 2002; Verhage et al., 2000; Voets et al., 2001; Weimer et al., 2003). Munc13s are thought to facilitate SNARE complex formation by keeping Syntaxin in an open conformation (Betz et al., 1997; Brose et al., 2000; Richmond et al., 2001). Although SNARE complex formation was originally thought occur downstream of a separate vesicle 
docking step (Broadie et al., 1995; Hunt et al., 1994; Sørensen et al., 2003; Voets et al. 2001; Washbourne et al., 2002), more recent evidence indicates that at least in $C$. elegans both Syntaxin and Unc-13 are required for vesicle docking. Docking defects in unc-13 mutant worms are rescued by the open form of Syntaxin, which indicates that SNARE complex formation may equal vesicle docking, with Unc-13 acting upstream of SNARE assembly (Hammerlund et al., 2007). In C.elegans, docking and exocytosis of SVs appears to require Unc-13 and Syntaxin, whereas docking and exocytosis of large dense core vesicles involves Caps and Syntaxin (Hammarlund et al., 2007; Hammarlund et al., 2008; Speese et al., 2007; Zhou et al., 2007), with Unc-13 playing a potential auxiliary role (Zhou et al., 2007; Hammarlund et al., 2008). By contrast, a clear division of labor between Munc-13 and Caps proteins in the regulation of SV and LDCV exocytosis does not appear to be a feature of the mammalian system. In mouse neurons, effective excitation-secretion coupling of SVs requires both Munc13 and Caps proteins (Jockusch et al. 2007), and our study shows that LDCV exocytosis, which has previously been shown to require Caps (Elhamadani et al., 1999; Liu et al., 2008), is also regulated by Munc13-1 and -2. Since physical docking of LDCVs in chromaffin cells also requires Syntaxin (de Wit et al., 2006), we propose that Munc13-1 and Munc13-2 regulate LDCV exocytosis by acting upstream of SNARE complex assembly, which does however not exclude the possibility that they have additional functions within the fusion machinery.

Our electrophysiological analysis of the role of Baiap3 in LDCV exocytosis suggests that Baiap3 acts as a negative regulator at the same step that requires Munc13-1 and -2 . This notion is also supported by our biochemical data, which show that Baiap3 can bind to Syntaxin1 as well as to Munc13-1. It is therefore conceivable that Baiap3 and other Munc13 isoforms compete for binding to Syntaxin and other SNARE complex 
components. Although we were unable to show that Baiap3 interferes with the binding of Munc13-1 to Syntaxin1, this may be an experimental limitation due to the fact that Munc13 does not interact with purified Syntaxin in solution (Basu et al., 2005) and the interaction therefore most likely requires additional factors. Because of the limited sequence similarity of Munc13-1 and Baiap3 (Table 2), they are unlikely to share all interaction partners, and binding of Baiap3 to Syntaxin may thus result in a configuration that is unfavorable to SNARE complex assembly

Other components of the fusion machinery for which a negative regulatory function in LDCV exocytosis has been reported are Amysin, Tomosyn (Yizhar et al., 2004; Constable et al., 2005) and Complexins (Archer et al., 2002; Itakura et al., 1999). Amysin and Tomosyn are a Syntaxin binding proteins with a C-terminal SNARE motif able form a fusion-incompetent SNARE complex with Syntaxin and SNAP-25 (Fujita et al., 1998; Scales et al., 2002; Pobbati et al., 2004; Groffen et al., 2005;). In C. elegans, Tomosyn antagonizes Unc-13-dependent release (Gracheva et al., 2006; McEwen et al., 2006) and also negatively regulates CAPS-dependent peptide release from dense core vesicles (Gracheva et al., 2007). By comparison, the evidence that Complexins are negative regulators of exocytosis is weak, because although overexpression impairs exocytosis (Archer et al., 2002; Itakura et al., 1999), their deletion does the same (Reim et al., 2001), suggesting that their in vivo function is not an inhibitory one. In our case, the overexpression and deletion of Baiap3 resulted in compatible data sets, i.e. overexpression reduced LDCV exocytosis and deletion enhanced it. Since the effect of overexpression was greater than the effect of deletion, the efficacy of Baiap3 in interfering with Munc13-dependent docking/priming appears to be sensitive to the relative protein levels of Baiap3 and the other Munc13s. High levels of Baiap3 could 
potentially sequester Syntaxin or Munc13, or both, thereby lowering the rate at which productive SNARE complexes are formed. However, the question remains, whether inhibition of LDCV exocytosis is the "true" function of Baiap3, or whether it is also a docking/priming factor, albeit a less efficient one.

To answer the open questions with respect to the mechanism of Baiap3 function it will also be necessary to determine its function in neurons. In the brain, Baiap3 has a more restricted expression pattern than Munc13-1 and Munc13-2, with prominent expression seen in hypothalamus, amygdala, periaqueductal grey, septum and several brainstem nuclei. We did not find obvious alterations in synaptic release of glutamate or GABA from cultured hypothalamic neurons, arguing against a function of Baiap3 in suppressing SV exocytosis. However, we were unable to reliably detect Baiap3 expression by staining cultured neurons (data not shown), and it remains to be investigated whether those neurons that express Baiap3 in the intact brain survived in our cultures. Potentially, Baiap3 could also function as a regulator of LDCV exocytosis in neurons, and/or be involved in the vesicular release of neurotransmitters other than GABA and glutamate.

\subsection{Conclusions}

I set out to determine whether mammalian LDCV exocytosis requires the same Munc13 isoforms that are essential for SV exocytosis, or whether the Munc13 relative Baiap3 might be more important for LDCV release. Two of the three neuronal Munc13 isoforms, Munc13-1 and Munc13-2, do indeed regulate LDCV exocytosis from mouse 
chromaffin cells, and thus play a more significant role in LDCV exocytosis than their C.elegans counterpart Unc-13. I found that Baiap3 is also a regulator of LDCV exocytosis, but against all expectations, it functions to suppress LDCV exocytosis, making it the first member of the Munc13 protein family for which a negative regulation of SNARE-mediated exocytosis has been described.

\subsection{Future Studies}

Future experiments to further delineate the role of Munc13s and Baiap3 in mammalian LDCV exocytosis will include ultrastructural analysis of possible LDCV docking defects in Munc13-1/2 and Baiap3 deficient chromaffin cells by electron microscopy. Docking defects in the in Munc13 deficient neurons have not been described (Varoqueaux et al. 2002), however, it is possible that such docking defects were missed due to fixation artifacts (Hammerlund et al. 2008). In C.elegans, the Unc-13 docking deficit, as well as the functional release deficit was rescued if Tomosyn was deleted as well, implying that Unc-13 and Tomosyn are true functional antagonists (Gracheva et al., 2006; McEwen et al., 2006). Comparison of the number of docked vesicles in Munc13-1/2 KO and Baiap3 KO cells, combined with functional analysis of LDCV exocytosis in Munc13-1/2/Baiap3 triple deficient cells, may thus answer the question whether the same is true for Baiap3 and Munc13s. 


\section{References}

Allersma, M.W., Wang, L., Axelrod, D., and Holz, R.W. Visualization of regulated exocytosis with a granule-membrane probe using total internal reflection microscopy (2004). Mol Biol Cell 15, 4658-4668.

Andrew-Zwilling, YS., Kawabe, H., Reim, K., Varoqueaux, F., and Brose, N. Binding to Rab3a-interacting-molecule RIM regulates the presynaptic recruitment of Munc13-1 and ubMunc13-2 (2006). J Biol Chem 281, 19720-19731.

Aravamudan, B., Fergested, T., Davis, WS., Rodesch, CK., and Broadie, K. Drosophila Unc-13 is essential for synaptic transmission (1999). Nat Neurosci 2, 965-971.

Archer, DA., Graham, ME., and Burgoyne, RD. Complexin regulates the closure of the fusion pore during regulated vesicle exocytosis (2002). J Biol Chem 277, 18249-18252.

Ashery, U., Betz, A., Xu, T., Brose, N., and Rettig, J. An efficient method for infection of adrenal chromaffin cells using the semliki Forest virus gene expression system (1999). Eur J Cell Biol 78, 525-32.

Ashery, U., Varoqueaux, F., Voets, T., Betz, A., Thakur, P., Koch, H., Neher, E., Brose, N., and Rettig, J. Munc13-1 acts as a priming factor for large dense-core vesicles in bovine chromaffin cells (2000). EMBO J 19, 3586-3596.

Augustin, I., Betz, A., Herrmann, C., Jo, T., and Brose, N. Differential expression of two novel Munc13 proteins in rat brain (1999a). Biochem J 337, 363-371.

Augustin, I., Rosenmund, C., Südhof, TC., and Brose, N. Munc13-1 is essential for fusion competence of glutamatergic synaptic vesicles (1999b). Nature 400, 457-461.

Augustin, I., Korte, S., Rickmann, M., Kretzschmar, H.A., Südhof, T.C., Herms, J.W., and Brose, N. The Cerebellum-specific Munc13 isoform Munc13-3 regulates cerebellar synaptic transmission and motor learning in Mice (2001). J Neurosci 21, 10-17. 
Bai, J., and Chapman, ER. The C2 domains of Synaptotagmin partners in exocytosis (2004). Trends Biochem Sci 29, 143-151.

Bai, J., Wang, CT., Richards, DA., Jackson, MB., and Chapman, ER. Fusion pore dynamics are regulated by synaptotagmin t-SNARE interactions (2004). Neuron 41, 929-942.

Basu, J., Shen, N., Dulubova, I., Lu, J., Guan, R., Guryev, O., Grishin, N.V., Rosenmund, C., and Rizo, J. A minimal domain responsible for Munc13 activity (2005). Nat Struct Mol Biol 12, 1017-1018.

Becherer, U., and Rettig, J. Vesicle pools, docking, priming, and release (2006). Cell Tissue Res 326, 393-407.

Betz, A., Ashery, U., Rickmann, M., Augustin, I., Neher, E., Südhof, TC., Rettig, J., and Brose, N. Munc13-1 is a presynaptic phorbol ester receptor that enhances neurotransmitter release (1998). Neuron 21, 123-136.

Betz, A., Okamoto, M., Benseler, F., and Brose, N. Direct interaction of the Rat unc-13 homologue Munc13-1 with the N terminus of Syntaxin (1997). J Biol Chem 272, 25202526.

Betz, A., Thakur, P., Junge, H.J., Ashery, U., Rhee, JS., Scheuss, V., Rosenmund, C., Rettig, J., and Brose, N. Functional interaction of the active zone proteins Munc13-1 and RIM1 in synaptic vesicle priming (2001). Neuron 30, 183-196.

Bollmann, JH., Sakmann, B., and Borst, JG. Calcium sensitivity of glutamate release in a calyx-type terminal (2000). Science 289, 953-957.

Brenner, S. The genetics of Caenorhabditis elegans (1974). Genetics 77, 71-94.

Broadie, K., Prokop, A., Bellen, HJ., O'Kane, CJ., Schulze, KL., and Sweeney, ST. Syntaxin and synaptobrevin function downstream of vesicle docking in Drosophila (1995). Neuron 15, 663-73. 
Brose, N. For better or for worse: Complexins regulates SNARE function and vesicle fusion (2008). Traffic 9, 1403-1413.

Brose, N., Hofmann, K., Hata, Y., and Südhof, T.C. Mammalian homologues of Caenorhabditis elegans unc-13 gene define novel family of C2-domain proteins (1995). J Biol Chem 270, 25273-25280.

Brose, N., Petrenko, AG., Südhof, TC., and Jahn, R. Synaptotamin: a calcium sensor on the synaptic vesicle surface (1992). Science 256, 1021-1025.

Brose, N., Rosenmund, C., and Rettig, J. Regulation of transmitter release by Unc-13 and ist homologues (2000). Curr Opin Neurobiol 10, 303-311.

Burgoyne, RD., and Morgan, A. Secretory granule exocytosis (2003). Physiol Rev 83, 581-632.

Carmichael, SW., and Winkler, H. The adrenal chromaffin cell (1985). Scientific American 253, 40-49.

Cases-Langhoff, C., Voss, B., Garner, AM., Appeltauer, U., Takei, K., Kindler, S., Veh, RW., De Camilli, P., Gundelfinger, ED., and Garner, CC. Piccolo, a novel 420 kDa protein associated with the presynaptic cytomatrix (1996). Eur J Cell Biol 69, 214-223.

Chan, AM., and Weber, T. A putative link between exocytosis and tumor development (2002). Cancer Cell 2, 427-8.

Chapman, ER., Hanson, PI., An, S., and Jahn, R. $\mathrm{Ca}^{2+}$ regulates the interaction between synaptotagmin and syntaxin 1 (1995). J Biol Chem 270, 23667-23671.

Constable, JRL., Graham, ME., Morgan, A., and Burgoyne, RD. Amisyn regulates exocytosis and fusion pore stability by both syntaxin-dependent and syntaxinindependent mechanisms (2005). J Biol Chem 280, 31615-31623. 
Craxton, M. Synaptotamin gene content of the sequenced genomes (2004). BMC Genomics 5, 43.

Dai, H., Tomchick, DR., García, J., Südhof, TC., Machius, M., and Rizo, J. Crystal structure of the RIM2 C2A-domain at $1.4 \AA$ resolution (2005). Biochemistry 44, 13533 13542.

de Wit, H., Cornelisse, LN., Toonen, RF., and Verhage, M. Docking of secretory vesicles is syntaxin dependent (2006). PLoS ONE 27, e126.

Dietrich, D., Kirschstein, T., Kukley, M., Pereverzec, A., von der Brelie, C., Schneider, T., and Beck,. H. Functional specialization of presynaptic Cav2.3 $\mathrm{Ca}^{2+}$ channels (2003). Neuron 39, 483-496.

Dikeakos, JD., and Reudelhuber, TL. Sending proteins to dense core secretory granules: still a lot to sort out (2007). J Cell Biol 177, 191-196.

Elhamdani, A., Martin, TF., Kowalchyk, JA., and Artalejo, CR. $\mathrm{Ca}^{2+}$-dependent activator protein for secretion is critical for the fusion of dense-core vesicles with the membrane in calf adrenal chromaffin cells (1999). J Neurosci 19, 7375-83.

Feldmann, J., Callebaut, I., Raposo, G., Certain, S., Bacq, D., Dumont, C., Lambert, N., Chardin, M.O., Chedeville, G., Tamary, H., Minard-Colin, V., Vilmer, E., Blanche, S., Le Deist, F., Fisher, A., and de Saint Basile, G. Munc13-4 is essential for cytolytic granules fusion and is mutated in a form of familial hemophagocytic lymphohistiocytosis (FHL3) (2003). Cell 115, 461-473.

Fujita, Y., Shirataki, H., Sakisaka, T., Asakura, T., Ohya, T., Kotani, H., Yokoyama, S., Nishioka, H., Matsuura, Y., Mizoguchi, A., Scheller, RH., and Takai, Y. Tomosyn: a syntaxin-1-binding protein that forms a novel complex in the neurotransmitter release process (1998). Neuron 20, 905-915.

Gillis, KD., Mossner, R., and Neher, E. Protein kinase C enhances exocytosis from chromaffin cells by increasing the size of the readily releasable pool of secretory 
granules (1996). Neuron 16, 1209-20.

Gracheva, EO., Burdina, AO., Holgado, AM., Berthelot-Grosjean, M., Ackley, BD., Hadwiger, G., Nonet, ML., Weimer, RM., and Richmond, JE. Tomosyn inhibits synaptic vesicle priming in C. elegans (2006). PLoS Biol 4, 1426-1437.

Gracheva, EO., Burdina, AO., Touroutine, D., Berthelot-Grosjean, M., Parekh, H., and Richmond, JE. Tomosyn negatively regulates CAPS-dependent peptide release at C.elegans synapses (2007). J Neurosci 27, 10176-10184.

Grynkiewicz, G., Poenie, M., and Tsien, RY. A new generation of $\mathrm{Ca}^{2+}$ indicators with greatly improved fluorescence properties (1985). J Biol Chem 260, 3440-3450.

Groffen, AJ., Friedrich, R., Brian, EC., Ashery, U., and Verhage, M. DOC2A and DOC2B are sensors for neuronal activity with unique calcium-dependent and kinetic properties (2006). J Neurochem 97, 818-33.

Guan, R., Dai, H., and Rizo, J. Binding of the Munc13-1 MUN domain to membraneanchored SNARE complexes (2008). Biochemistry 47, 1474-1481.

Hammarlund, M., Palfreyman, MT., Watanabe, S., Olsen, S., and Jorgensen, EM. Open syntaxin docks synaptic vesicles (2007). PLoS Biol 5, 1695-1711.

Hammarlund, M., Watanabe, S., Schuske, K., and Jorgensen, EM. CAPS and syntaxin dock dense core vesicles to the plasma membrane in neurons (2008). J Cell Biol 180, 483-491.

Hayashi, T., Yamasaki, S., Nauenburg, S., Binz, T., and Niemann, H. Disassembly of the reconstituted synaptic vesicle membrane fusion complex in vitro (1995). EMBO J $14,2317-2325$.

Hosono, R., and Kamiya, Y. Additional genes which result in an elevation of acetylcholine levels by mutations in Caenorhabditis elegans (1991). Neurosci Lett 128, 243-244. 
Hunt, JM., Bommert, K., Charlton, MP., Kistner, A., Habermann, E., Augustine, GJ., and Betz, H. A post-docking role for synaptobrevin in synaptic vesicle fusion (1994). Neuron 12, 1269-1279.

Itakura, M., Misawa, H., Sekiguchi, M., Takahashi, S., and Takahashi, M. Transfection analysis of functional roles of complexin I and II in the exocytosis of two different types of secretory vesicles (1999). Biochem Biophys Res Commun 265, 691-696.

Jahn, R., Lang, T., and Südhof, TC. Membrane fusion (2003). Cell 112, 519-33.

Jahn, R., and Scheller, RH. SNAREs-engines for membrane fusion (2006). Nat Rev Mol Cell Biol 7, 631-643.

Jockusch, WJ., Speidel, D., Sigler, A., Sørensen, JB., Varoqueaux, F., Rhee, JS., and Brose, N. CAPS-1 and CAPS-2 are essential synaptic vesicle priming proteins (2007). Cell 131, 796-808.

Junge, H.J., Rhee, J.S., Jahn, O., Varoqueaux, F., Spiess, J., Waxham, M.N., Rosenmund, C., and Brose, N. Calmodulin and Munc13 form a $\mathrm{Ca}^{2+}$ sensor/effector complex that controls short-term synaptic plasticity (2004). Cell 118, 389-401.

Kee, Y., and Scheller, RH. Localization of synaptotagmin-binding domains on syntaxin. J Neurosci 16, 1975-1981.

Kim, TY., Gondre-Lewis, MC., Arnaoutova, I., and Loh, YP. Dense-core secretory granule biogenesis (2006). Physiology 21, 124-133.

Koch, H., Hofmann, K., and Brose, N. Definition of Munc13-homology-domains and characterization of a novel ubiquitously expressed Munc13 isoform (2000). Biochem J 349, 247-253.

Krasnoperov, VG., Bittner, MA., Beavis, R., Kuang, Y., Salnikow, KV., Chepurny, OG., Little, AR., Plotnikov, AN., Wu, D., Holz, RW., and Petrenko, AG. $\alpha$-Latrotoxin 
stimulates exocytosis by the interaction with a neuronal G-protein-coupled receptor (1997). Neuron 18, 925-937.

Lelianova, VG., Davletov, BA., Sterling, A., Rahman, MA., Grishin, EV., Totty, NF., and Ushkayov, YA. $\alpha$-Latrotoxin receptor, latrophilin, is a novel member of the secretion family of G-protein-coupled receptors (1997). J Biol Chem 272, 21504-21508.

Li, C., Ullrich, B., Zhang, JZ., Anderson, RG., Brose, N., and Südhof, TC. $\mathrm{Ca}^{2+}$ dependent and independent activities of neuronal and non-neuronal synaptotagmins (1995). Nature 375, 594-599.

Liu, Y., Schirra, C., Stevens, DR., Matti, U., Speidel, D., Hof, D., Bruns, D., Brose, N., and Rettig, J. CAPS facilitates filling of the rapidly releasable pool of large dense core vesicles (2008). J Neurosci 28, 5594-5601.

Lu, J., Machius, M., Dulubova, I., Dai, H., Südhof, TC., Tomchick, DR., and Rizo, J. Structural basis for a Munc13-1 homodimer to Munc13-1/RIM heterodimer switch (2006). PLoS Biol 4, e192.

Martin, TFJ. The molecular machinery for fast and slow neurosecretion (1994). Curr Opin Neurobiol 4, 626-632.

McEwen, JM., Madison, JM., Dybbs, M., and Kaplan, JM. Antagonistic regulation of synaptic vesicle priming by Tomosyn and UNC-13 (2006). Neuron 51, 303-315.

Neeft, M., Wieffer, M., de Jong, AS., Negroju, G., Metz, CHG., van Loon, A., Griffith, J., Krijgsveld, J., Wulffraat, N., Koch, H., Heck, A., Brose, N., Kleijmeer, M., and van der Sluijs, P. Munc13-4 is an effector of Rab27a and controls secretion of lysosomes in hematopoietic cells (2005). Mol Biol Cell 16, 731-741.

Neher, E. A comparison between exocytotic control mechanisms in adrenal chromaffin cells and a glutamatergic synapse (2006). Pflugers Arch 453, 261-268. 
Nonet, ML., Saifee, O., Zzhao, H., Rand, JB., and Wie, L. Synaptic transmission deficits in C.elegans synaptobrevin mutants (1998). J Neurosci 18, 70-80.

Olofsson, CS., Gopel, SO., Barg, S., Galvanovski, J., Ma, X., Salehi, A., Rorsman, P., and Eliasson, L., Fast insulin secretion reflects exocytosis of docked granules in mouse pancreatic $\beta$-cells (2002). Pflugers Arch 444, 43-51.

Palmer, R., Lee, S.B., Wong, J.C., Reynolds, P.A., Zhang, H., Truong, V., Oliner, J.D., Gerald, W.L., and Haber, D.A. Induction of BAIAP3 by the EWS-WT1 chimeric fusion implicates regulated exocytosis in tumorigenesis (2002). Cancer Cell 2, 497-505.

Parsons, TD., Coorssen, JR., Horstmann, H., and Almers, W. Docked granules, the exocytotic burst, and the need for ATP hydrolysis in endocrine cells (1995). Neuron 15, 1085-1096.

Pobbati, AV., Razeto, A., Böddener, M., Becker, S., Fasshauer, D. Structural basis for the inhibitory role of tomosyn in exocytosis (2004). J Biol Chem 279, 47192-47200.

Reim, K., Mansour, M., Varoqueaux, F., McMahon, HT., Südhof, TC., Brose, N., and Rosenmund, C. Complexins regulate a late step in $\mathrm{Ca}^{2+}$-dependent neurotransmitter release (2001). Cell 104, 71-81.

Rhee, J.S., Betz, A., Pyott, S., Reim, K., Varoqueaux, F., Augustin, I., Hesse, D., Südhof, T.C., Takahashi, M., Rosenmund, C., and Brose, N. $\beta$-phorbol ester- and diacylglycerol-induced augmentation of transmitter release is mediated by Munc13s and not by PKCs (2002). Cell 108, 121-133.

Richmond, JE., Davis, WS., and Jorgensen, EM. UNC-13 is required for synaptic vesicle fusion in C.elegans (1999). Nat Neurosci 2, 959-964.

Richmond, JE., Weimer, RM., and Jorgensen, EM. An open form of syntaxin bypasses the requirement for UNC-13 in vesicle priming (2001). Nature 412, 338-41. 
Rickman, C., and Davletov, B. Mechanisms of calcium-independent synaptotagmin binding to target SNAREs (2003). J Biol Chem 278, 5501-5504.

Rizo, J., Rosenmund, C. Synaptic vesicle fusion (2008). Nat Struct Mol Biol 15, 66574.

Rupnik, M., Kreft, M., Sikdar, SK., Grilc, S., Romih, R., Zupancic, G., Martin, TF., and Zorec, R. Rapid regulated dense-core vesicle exocytosis requires the CAPS protein (2000). Proc Natl Acad Sci U S A 97, 5627-32.

Rutter GA, Hill EV. Insulin vesicle release: walk, kiss, pause ... then run (2006). Physiology (Bethesda) 21, 189-96.

Sadakata T., Kakegawa, W., Mizoguchi, A., Washida, M., Katoh-Semba, R., Shutoh, F., Okamoto, T., Nakashima, H., Kimura, K., Tanaka, M., Sekine, Y., Itohara, S., Yuzaki, M., Nagao, S., and Furuichi, T. Impaired cerebellar development and function in mice lacking CAPS2, a protein involved in neurotrophin release (2007). J Neurosci 27, 24722482.

Sadakata, T., Mizoguchi, A., Sato, Y., Katoh-Semba, R., Fukuda, M., Mikoshiba, K., and Furuichi, T. The secretory granule-associated protein CAPS2 regulates neurotrophin release and cell survival (2004). J Neurosci 24, 43-52.

Scales, SJ., Hesser, BA., Masuda, ES., and Scheller, RH. Amisyn, a novel syntaxinbinding protein that may regulate SNARE complex assembly (2002). J Biol Chem 277, 28271-28279.

Schneggenburger, R., and Neher, E. Presynaptic calcium and control of vesicle fusion (2005). Curr Opin Neurobiol 15, 266-74.

Schoch, S., Castillo PE., Jo, T., Mukherjee, K., Geppert, M., Wang, Y., Schmitz, F., Malenka, RC., and Südhof, TC. RIM $1 \alpha$ forms a protein scaffold for regulrating neurotransmitter release at the active zone (2002). Nature 415, 321-326. 
Schoch, S., Deak, F., Konigstorfer, A., Mozhayeva, M., Sara, Y., Südhof, TC., and Kavalali, ET. SNARE function analyzed in synaptobrevin/VAMP knockout mice (2001). Science 294, 1117-1122.

Schulze, KL., Broadie, K., Perin, MS., and Bellen, HJ. Genetic and electrophysiological studies of Drosophila syntaxin-1A demonstrate its role in nonneuronal secretion and neurotransmission (1995). Cell 80, 311-320.

Serra-Pages, C., Medley, QG., Tang, M., Hart, A., and Streuli, M. Liprins, a family LAR transmembrane protein-tyrosine phosphatase-interacting proteins (1998). J Biol Chem 273, 15611-15620.

Shiratsuchi, T., Oda, K., Nishimori, H., Suzuki, M., Takahashi, E., Tokino, T., and Nakamura, Y. Cloning and Charaterization of Baiap3 (BAI-Associated Protein 3), a C2 domain-containing protein that interacts with BAI1 (1998). Biochem Biophys Res Commun 251, 158-165.

Söllner, T., Whiteheart, SW., Brunner, W., Erdjument-Bromage, N., Geromanos, S., Tempst, P., and Rothman, JE. SNAP receptors implicated in vesicle targeting and fusion (1993). Nature 362, 318-324.

Sørensen, JB., Nagy, G., Varoqueaux, F., Nehring, RB., Brose, N., Wilson, MC., and Neher, E. Differential control of the releasable vesicle pools by SNAP-25 splice variants and SNAP-23 (2003). Cell 114, 75-86.

Speese, S., Petrie, M., Schuske, Kim., Ailion, M., Ann, K., Iwasaki, K., Jorgensen, EM., and Martin, TFJ. UNC-31 (CAPS) is required for dense core vesicle but not synaptic vesicle exocytosis in C. elegans (2007). J Neurosci 27, 6150-6162.

Stevens, DR., Wu, ZX., Matti, U., Junge, H.J., Schirra, C., Becherer, U., Wojcik, S.M., Brose, N., and Rettig, J. Identification of the Minimal Protein Domain Required for Priming Activity of Munc13-1 (2005). Curr Biol 15, 1-6. 
Südhof, TC. The Synaptic Vesicle Cycle: a cascade of protein-protein interactions (1995). Nature 375, 645-653.

Südhof, TC. The Synaptic Vesicle Cycle (2004). Annu Rev Neurosci 27, 509-547.

Tandon, A., Bannykh, S., Kowalchyk, JA., Banerjee, A., Martin, TF., and Balch, WE. Differential regulation of exocytosis by calcium and CAPS in semi-intact synaptosomes (1998). Neuron 21, 147-54.

tom Dieck, S., Sanmarti-Vila, L., Langnaese, K., Richter, K., Kindler, S., Soyke, A., Wex, H., Smalla, KH., Kämpf, U., Fränzer, JT., Stumm, M., Garner, CC., and Gundelfinger ED. Bassoon, a novel zinc-finger CAG/glutamine-repeat protein selectively localized at the active zone of presynaptic nerve terminals (1998). J Cell Biol 142, 499-509.

Trifaro, JM. Molecular biology of the chromaffin cells (2002). Ann N Y Acad Sci 971, 11-18.

Varoqueaux, F., Sigler, A., Rhee, JS., Brose, N., Enk, C., Reim, K., and Rosenmund, C. Total arrest of spontaneous and evoked synaptic transmission but normal synaptogenesis in the absence of Munc13-mediated vesicle priming (2002). Proc Natl Acad Sci U S A 99, 9037-9042.

Varoqueaux, F., Sons, M.S., Plomp, J.J., and Brose, N. Aberrant Morphology and residual transmitter release at the Munc13-deficient mouse neuromuscular synapse (2005). Mol Cell Biol 25, 5973-5984.

Verhage, M., Maia, AS., Plomp, JJ., Brussaard, AB., Heeroma, JH., Vermeer, H., Toonen, RF., Hammer, RE., van den Berg, TK., Missler, M. Synaptic assembly of the brain in the absence of neurotransmitter secretion (2000). Science 287, 864-869.

Voets, T. Dissection of three Ca2+- dependent steps leading to secretion in chromaffin cells from mouse adrenal slices (2000). Neuron 28, 537-545. 
Voets, T., Neher, E., and Moser, T. Mechanisms underlying phasic and sustained secretion in chromaffin cells from mouse adrenal slices (1999). Neuron 23, 607-615.

Voets, T., Toonen, RF., Brian, EC., de Wit, H., Moser, T., Rettig, J., Suedhof, TC., Neher, E., and Verhage, M. Munc18-1 promotes large dense-core vesicle docking (2001). Neuron 31, 581-591.

Wang, Y., Liu, X., Biederer, T., and Südhof, TC. A family of RIM-binding proteins regulated by alternative splicing: implications for the genesis of synaptic active zones (2002). Proc Natl Acad Sci U S A 99, 14464-14469.

Wang, Y., Okamoto, M., Schmitz, F., Hofman, K., and Südhof, TC. RIM: a putative Rab3-effector in regulating synaptic vesicle fusion (1997). Nature 388, 593-598.

Wang, Y., Sugita, S., and Südhof, TC. The RIM/NIM family of neuronal C2 domain proteins. Interactions with Rab3 and a new class of Src homology 3 domain proteins (2000). J Biol Chem 275, 20033-20044.

Washbourne, P., Thompson, PM., Carta, M., Costa, ET., Mathews, JR., Lopez-Bendito, G., Molnar, Z., Becher, MW., Valenzuela, CF., Partridge, LD., and Wilson, MC. Genetic ablation of the t-SNARE SNAP-25 distinguishes mechanisms of neuroexocytosis (2002). Nat Neurosci 5, 19-26.

Weimer, RM., Richmond, JE., Davis, WS., Hadwiger, G., Nonet, ML., and Jorgensen, EM. Defects in synaptic vesicle docking in unc-18 mutants (2003). Nat Neurosci. 6, 1023-1030.

Wojcik, SM., and Brose, N. Regulation of membrane fusion in synaptic excitationsecretion coupling: speed and accuracy matter (2007). Neuron 55, 11-24.

Xu, T., Binz, T., Niemann, H., and Neher, E. Multiple kinetic components of exocytosis distinguished by neurotoxin sensitivity (1998). Nature 1, 192-200. 
Yizhar, O., Matti, U., Melamed, R., Hagalili, Y., Bruns, D., Rettig, J., and Ashery, U. Tomosyn inhibits priming of large dense-core vesicles in a calcium-dependent manner (2004). Proc Natl Acad Sci U S A 101, 2578-2583.

Zhou, KM., Dong, YM., Ge, Q., Zhu, Dan., Zhou, W., Lin, XG., Liang, T., Wu, ZX., and $\mathrm{Xu}, \mathrm{T}$. PKA activation bypasses the requirement for UNC-31 in the docking of dense core vesicles from C.elegans neurons (2007). Neuron 56, 657-669.

Zikich, D., Meser, A., Varoqueaux, F., Sheinin, A., Junge, H.J., Nachliel, E., Melamed, R., Brose, N., Gutman, M., and Ashery, U. Vesicle priming and recruitment by ubMunc13-2 are differentially regulated by calcium and calmodulin (2008). J Neurosci 28, 1949-1960.

Zucker RS. Exocytosis: A Molecular and Physiological Perspective (1996). Neuron 17, 1049-1055. 


\section{Summary}

Members of mammalian uncoordinated 13 protein family (Munc13s) are essential for SV exocytosis in neurons and have also been implicated in LDCV exocytosis in chromaffin cells. However, the C.elegans ortholog Unc-13 appears to be dispensable for LDCV exocytosis, raising the question whether SNARE-mediated exocytosis of SVs and LDCVs is controlled by distinct regulatory proteins. We therefore analyzed LDCV exocytosis in cultured chromaffin cells taken from knockout mouse lines of four members of the Munc13 protein family, Munc13-1, Munc13-2, Munc13-3 and Baiap3. Baiap3/Bap3 (brain specific angiogenesis inhibitor 1 associated protein 3), was identified and named as an interaction partner of BAI 1 (brain specific angiogenesis inhibitor-1), and is a Munc13 homologue of unknown function. Its closet known relative, the non-neuronal Munc13-4, has been shown to be essential for the secretion of lymphocyte cytolytic granule content. Unlike Munc13-4, Baiap3 expression is largely restricted to brain and adrenal gland, with low levels also present in lung. To determine whether LDCV exocytosis is impaired in the absence of Munc13-1, Munc13-2, Munc13-3 or Baiap3, we combined flash photolysis of caged $\mathrm{Ca}^{2+}$ and membrane capacitance measurements in cultured chromaffin cells. Our analysis of exocytosis in chromaffin cells shows that Munc13-1 and Munc13-2 act as positive regulators of LDCV exocytosis and play a more critical role in the release of this vesicle type than their C.elegans ortholog Unc-13. Based on sequence similarity, Baiap3 is a member of the Munc13 protein family. However, unlike Munc13-1, -2, -3 and -4, which function as essential positive regulators of SNARE-mediated exocytosis, our data indicate that Baiap3 negatively regulators exocytosis, at least in chromaffin cells. In this study, we found that exocytosis in chromaffin cells from Munc13-1 deficient mice and mice lacking both Munc13-1 and Munc13-2, showed a dramatic reduction in LDCV 
exocytosis. In contrast to this, chromaffin cells deficient for Baiap3 showed increased exocytosis and Baiap3 overexpression in WT cells suppressed LDCV release. The exact molecular mechanism by which Munc13s regulate SNARE-mediated exocytosis remains to be elucidated. However, we found that Baiap3 interacted with both Munc131 and Syntaxin in co-sedimentation assays, which indicates that competition for binding to SNARE complex components is a possible explanation for the opposing functions of Munc13-1/2 and Baiap3 LDCV exocytosis. 


\section{Acknowledgments}

I would like to express my appreciation to God for his guidance throughout my life and research. I would also like to thank many people who were willing to assist in all things (research and living, etc) during my Ph.D course. Although it's so difficult to express my gratitude to them in words, it's a way of showing my appreciation to them. Firstly, I am indebted to Dr. Sonja M. Wojcik, who is my perfect supervisor. When I started living abroad, she helped me greatly in organizing my residence in Germany and with the language, experiments, etc... Moreover, despite some failed experiments during my Ph.D. course, she always, through encouragement, patience, and motivation, led me back on course to a successful Ph.D. I'm really honored have met and worked with Prof. Dr. Nils Brose, who is also a perfect director. I am really indebted to Nils for giving me an opportunity to join as a member of his fantastic laboratory. I am grateful to Dr. Jeong-seop Rhee, who is a smart adviser. I often consulted with him about all things in Korean (life, research, etc...). He advised me about them based on his own know-how. Many thanks to all colleagues from Department of Molecular Neurobiology at the Max Planck Institute for Experimental Medicine for creating a pleasant work atmosphere. Especially, thanks to Dr. Wolf J. Jockusch for his technical support of physiological experiments and Dr. Benjamin Cooper, Dr. Andrea Betz, Dr. Andrea Burgalossi, Dr. Alexandros Poulopoulos, Friederike Wolk and Ramya Nair for their support with official things and for interesting conversations. I would like to express my sincere gratitude to Prof. Dr. Ernst A. Wimmer, Prof. Dr. Ralf Heinrich, PD. Dr. Michael Hoppert, Prof. Dr. Dieter. Heineke, and Prof. Dr. Stefan Treue for agreeing to be in my thesis committee. I am grateful to the members of the Koreanische Ev. Kirchengemeinde in Goettingen, for making my life in Goettingen happy and enjoyable.

I thank MinKyu Cho and Hai-Young Kim, who as friends and advisers, shared 
problems, ambitions, the pleasures of life, science and each other. I am really grateful to my whole family; Parents (Shin, Bong-Rae and Kim, Chang-Soon), Parents in law (Kim, Tae-Kwon and Kang, Yun-Hee), Elder sisters (Shin, Eun-Hye and Shin, Eun-Hee), Brothers in law (Kim, Seung-Eon and Jung, Hak-Jae and Kim, Chi-Eon), Sisters in law (Kim, Mi-Kyung and Kim, Geum-Jung), Nieces (Kim, Hyeon-Gyeong and Kim, DoGyeong and Jung, Da-Yeon and Jung, Da-Vin), for their support and prayers towards the successful completion of my Ph.D course. Finally and importantly, I would like to express my gratitude to Kim, EunJung, who is my lovely wife, for her encouragement and assistance during our life abroad and in science. Moreover, she always takes care of our beloved daughter, Shin, ChaeWon, so I could concentrate on my research during the $\mathrm{Ph}$. D course. 


\section{About the Author}

Personal Data

Name:

Yong Shin

Birth:

01.02.1977 in Seoul

Nationality:

Republic of Korea

Marital Status:

Married, one daughter

Education

03/83-02/89

Kwan-ack Elementary School, Korea

03/89-02/92

Bong-Lim Middle school, Korea

03/92-02/95

Young Nak high school, Korea

03/95-02/02

Korea University (Bachelor Degree), Korea

03/03-02/05

Seoul National University (Master Degree), Korea

03/05-11/08

Georg-August-Universität (Biology), Germany

Research

09/01-02/05

National Cancer Center, Korea

(Center for Colorectal Cancer)

03/05- 11/08

Pre-doctoral training at Max Planck Institute for

Experimental Medicine, Göttingen, Germany

(Prof. Dr. Nils Brose's Laboratory) 


\section{List of Publications}

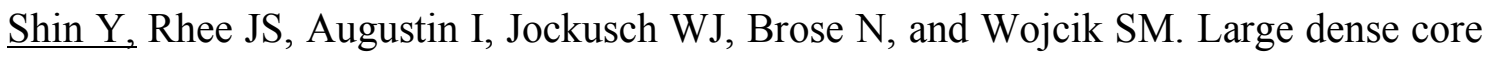
vesicle exocytosis in mouse chromaffin cells is regulated by Munc13s and Baiap3. In Preparation.

Lim SB, Jeong SY, Kim IJ, Kim DY, Jung KH, Chang HJ, Choi HS, Sohn DK, Kang HC, Shin Y, Jang SG, Park JH and Park JG. Analysis of microsatellite instability in stool DNA of patients with colorectal cancer using denaturing high performance liquid chromatography (2006). World. J. Gastroenterol 12, 6689-92.

Kang HC, Kim IJ, Park JH, Shin Y, Jang SG, An SA, Park HW, Lim SB, Oh SK, Kim DJ, Lee KW, Choi YJ, Park YJ, Lee MR, Kim DW and Park JG. Three novel VHL germline mutations in Korean patients with von Hippel-Lindau disease and pheochromocytomas (2005). Oncol Rep. 14, 879-883.

Kim DW, Kim IJ, Kang HC, Park HW, Shin Y, Park JH, Jang SG, Yoo BC, Lee MR, Hong CW, Park KJ, Oh NG, Kim NK, Sung MK, Lee BW, Kim YJ, Lee HS and Park JG. Mutation Spectrum of the APC gene in 83 Korean FAP Families (2005). Hum Mutation 26, 281-286.

Kim IJ, Kang HC, Shin Y, Yoo BC, Yang HK and Park JG. Familial gastric cancers with Li-Fraumeni syndrome: A case repast (2005). World J. Gastroenterol 14, 41244126.

Kim IJ, Ku JL, Kang HC, Park JH, Yoon KA, Shin Y, Park HW, Jang SG, Lim SK, Han SY, Shin YK, Lee MR, Jeong SY, Shin HR, Lee JS, Kim WH and Park JG. Mutational analysis of OGG1, MYH, MTH1 In FAP, HNPCC and sporadic colorectal cancer patients: R154H OGG1 polymorphism is associated with colorectal cancer patients (2004). Hum Genet 115, 498-503.

Kim IJ, Kang HC, Shin Y, Park HW, Jang SG, Han SY, Lim SK, Lee MR, Chang HJ, $\mathrm{Ku}$ JL, Yang HK and Park JG. A TP53-truncating germline mutation (E287X) in a family with characteristics of both Hereditary diffuse gastric cancer and Li-Fraumeni 
syndrome (2004). J Hum Genet 49, 591-595.

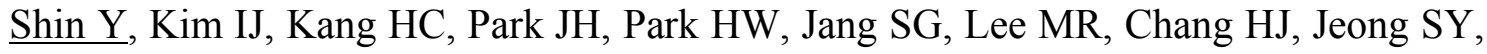
$\mathrm{Ku} \mathrm{JL}$ and Park JG.A functional polymorphism $-347 \mathrm{G} / \mathrm{GA}$ of E-cadherin gene is associated with colorectal cancer (2004). Carcinogenesis 25, 2173-2176.

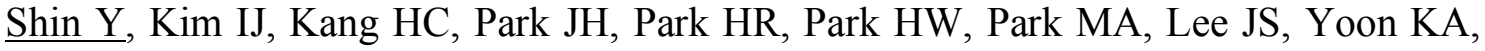
$\mathrm{Ku} \mathrm{JL}$ and Park JG. The E-cadherin -347G/GA promoter polymorphism and its effect on transcriptional regulation (2004). Carcinogenesis 25, 895-899.

Park JH, Kim IJ, Kang HC, Shin Y, Park HW, Jang SG, Ku JL, Lim SB, Jeong SY and Park JG. Oligonucleotide microarray-based mutation detection of the K-ras gene in colorectal cancers using Competitive DNA Hybridization (CDH) (2004). Clinical Chemistry 50, 1688-91.

Kang HC, Kim IJ, Park JH, Shin Y, Park HW, Ku JL, Yang HK, Lee KU, Choe KJ and Park JG. Promoter hypermethylation and silencing of CHFR mitotic stress checkpoint gene in human gastric cancers (2004). Oncology Reports 12, 129-133.

Kang HC, Kim IJ, Park JH, Shin Y, Jung MS, Yoo BC, Kim HK and Park JG. Differentially expressed genes in acquired drug-resistant gastric cancer cells by oligonucleotide microarrays (2004). Clinical Cancer Research 10, 272-284.

Kim IJ, Shin Y, Kang HC, Park JH, Ku JL, Park HW, Park HR, Lim SB, Jeong SY, Kim WH and Park JG. Robust microsatellite instability (MSI) analysis by denaturing high-performance liquid chromatography (DHPLC) (2003). J Hum Genet 48, 525-530.

Kim IJ, Park JH, Kang HC, Shin Y, Park HW, Park HR, Ku JL, Lim SB and Park JG. Mutational analysis of BRAF and K-ras in gastric cancers: absence of BRAF mutations in gastric cancers (2003). Hum Genet 114, 118-120.

Kim IJ, Park JH, Kang HC, Shin Y, Lim SB, Ku JL, Yang HK, Lee KU and Park JG. A novel germline mutation in the MET extracellular domain in a Korean patient with the diffuse type of familial gastric cancer (2003). J Med Genet 40, e97. 
Kim IJ, Kang HC, Park JH, Shin Y, Ku JL, Lim SB, Park SY, Jung SY., Kim HK and Park JG. Development and applications of a $\beta$-catenin oligonucleotide microarray: $\beta$ catenin mutations are dominantly found in the proximal colon cancers with microsatellite instability (2003). Clin. Cancer Res 9, 2920-2925.

Park JH, Kim IJ, Kang HC, Lee SH, Shin Y, Kim KH, Lim SB, Kang SB, Lee KU, Kim SY, Lee MS, Lee MK, Park JH, Moon SD and Park JG. Germline mutations of the MEN1 gene in Korean families with multiple endocrine neoplasia type 1 (MEN1) or MEN1-related disorders (2003). Clin Genet 64, 48-53.

Kang HC, Kim IJ, Park JH, Kwon HJ, Won YJ, Heo SC, Lee SY, Kim KH, Shin Y, Noh DY, Yang DH, Choe KJ, Lee BH, King SB and Park JG. Germline mutations of BRCA1 and BRCA2 in Korean breast and/or ovarian cancer families (2002). Hum Mutat 64, 48-53. 
